\title{
DEMOGRAPHIC TRENDS IN JAINA MONASTICISM
}

\author{
Peter Flügel
}

The study of Jainism as a living religion is still hampered by a lack of reliable sociological and demographic information both on the Jain laity and Jain mendicants. ${ }^{1}$ Most empirical studies to date have been thematically oriented or were of an exploratory nature. They were based on the methods advanced by the classical anthropological village studies or on small surveys of a nonrepresentative nature. ${ }^{2}$ In both cases, the units of investigation were defined in terms of observer categories ${ }^{3}$ which were often created ad hoc in the field due to the advantages of snowball sampling under conditions of limited resources. In a paper read at the American Oriental Society Meeting in 1978, at a time when comprehensive field studies had yet to be conducted, the late Kendall Folkert (1993: 156) suggested avoiding the inevitable abstractions of 'general accounts of the Jains' by concentrating on 'the smaller divisions within the tradition' which 'have actually been the basic units of the tradition'. What Folkert had in mind was to study the individual 'schools, sects or orders' (gaccha) of the Jain mendicant tradition, ${ }^{4}$ rather than 'Jain religious culture' in general. ${ }^{5}$ Certainly, not all Jains coalesce around monastic groups, but the majority does so in one way or another.

The investigation of categories which are recognised by the Jains themselves promises indeed to yield testable results of greater accuracy and relevance for the Jain community itself. However, the research programme envisaged by Folkert has yet to be implemented. ${ }^{6}$ Despite the pioneering studies of Vilas Sangave (1959/1980) on the social divisions of the Jain lay community and of Muni Uttam Kamal Jain (1975) on the pre-modern history of the religious divisions of the Jain mendicants, most students of Jainism, and indeed most Jains, have still no way of knowing how many independent mendicant orders exist today and how they are organised. ${ }^{7}$ The aim of this chapter is to fill this gap and to provide a brief overview of the present schools, orders and sects ${ }^{8}$ within both the Śvetāmbara- and the Digambara-denomination ${ }^{9}$ and to bring together the available demographic data on the current Jain monastic traditions. 
A comprehensive description of the Jain lay movements is beyond the scope of this chapter.

\section{Jain laity}

Although no studies of the demographic trends in Jain monasticism are currently available, general surveys of the Jain lay community have been produced on the basis of the available census data by Sangave (1959/1980), Sharma (1976) and M. K. Jain (1986). The inclusion of the category 'Jain'10 into the questionnaire for the Census of India $1881^{11}$ is widely regarded as one of the defining moments for the modern construction of Jainism as an independent 'religion'. ${ }^{12}$ It was introduced by the colonial government after Jacobi (1879) proved the historical independence of Jainism from Buddhism, and a number of high court judgements in favour of westernised Jains such Paṇịt Padmarāja (1886), J. L. Jaini (1916) and C. R. Jain (1926) who were interested in securing a privileged legal status for their community. However, notwithstanding the desire of the educated Jain elite to establish a clear-cut boundary between 'Jainism' and 'Hinduism', in the census itself many Jains continued to return themselves as 'Hindu'.

A number of explanations have been put forward for this. Amongst them 'enumerators' error' figures most prominently, since local volunteers frequently filled in the census forms themselves on the basis of their own local knowledge. ${ }^{13}$ Another interpretation suggests that many respondents were either unable or unwilling to make a distinction between the categories. They may have followed the example of their ancestors who often, in the fear of persecution, maintained an outward conformity with Hinduism (cf. Williams 1983: xix). In other words, they were not so much confronted with the question of 'who they were' (Cohn 1992: 248), but rather how they preferred to be perceived. ${ }^{14}$

Reform orientated Jain intellectuals were highly conscious of the problem of communal self-objectification already by the 1870 s, and in response to the low turnout of Jains in 1881 actively embraced the census as a medium of communal self-representation. At the turn of the twentieth century, the leaders of the newly founded Jain Conferences even designed petitions which actively encouraged community members to return themselves as 'Jain' and not as 'Hindu'. They also volunteered to carry out the census in their own communities in an attempt to boost the numbers and hence the importance of the Jain community in the eyes of the colonial government. ${ }^{15}$ Demographic growth was generally depicted as a sign of communal progress and used as an argument in contexts of 'democratic' politics of representation. ${ }^{16}$ This sentiment is still echoed today in the work of Vilas Sangave (1980) and other Jain intellectuals who lament the fact that, even after a century of communal revival, many Jains keep on regarding themselves and are regarded as Hindus, ${ }^{17}$ which 'necessarily vitiates the census figures and obscures the increase or decrease of the Jaina population from census to census' (ibid.: 3). ${ }^{18}$ 
The debate on whether Jains are culturally 'Hindus' or a 'minority community' wages unabated within the community. Thus far, Jain communalists have failed to establish the Jains 'as a separate social group' (ibid.: 411) against the opposition of many Śvetāmbara ācāryas. The majority of the Jain laity retains an ambiguous social identity midway between the Jain mendicant communities and the wider 'Hindu' society. It is therefore not surprising that still no reliable demographic data is available for the Jain laity. Certainly, the Jain community is very small. The official figure generated by the Census of India 1991 was $3,352,706$, that is, 0.4 per cent of the Indian population (Vijayanunni 1991: $\mathrm{x}-\mathrm{xi}$ ). The Census of 2001 produced the figure of 4,225,053, also 0.4 per cent of the Indian population (www. censusindia.net). In addition, about 150,000 Jains live outside India, but no mendicants. No data is available on the number of lay followers of particular Jain schools and sects, although some of these may be estimated on the basis of caste directories, in cases where caste and sect membership widely overlap.

\section{Jain mendicants}

The rhetoric of numbers, adopted by the Jain lay Conferences, also had a significant influence on the monastic orders, which were put under pressure to compete with each other not only in terms of behavioural purity and education, but also in terms of sheer numbers - in the name of democracy and modernisation. ${ }^{19}$ The rhetoric of numbers is not necessarily new, but no documents containing information on the actual number of Jain monks and nuns are known before the early-modern period.

There are two exceptions. The Jinacaritra in the so-called Paryuṣana Kalpa Sūtra, which was traditionally attributed to Bhadrabāhu I who is said to have lived c. 170 or 162 years after Mahāvīra although the Jinacaritra is certainly much younger, tells us that Mahāvīra's four-fold community comprised of

fourteen thousand Śramaṇas with Indrabhūti at their head; thirty-six thousand nuns with Candanā at their head; one hundred and fifty-nine thousand lay votaries with Sankhașataka at their head; three hundred and eighteen thousand female lay votaries with Sulasā and Revatī at their head.

(Jinacaritra 136f., in Jacobi 1884: 267f.)

The Sthavirāvalī, or List of the Elders, which is generally attributed to Devarddhi Gani, the fifth century CE redactor of the Śvetāmbara canon, mentions not 14,000, but merely 4,411 monks and gives no total figures for nuns and laity (Sthavirāvalī 1, in Jacobi 1884: 286f.). Both of these accounts, colltected in the same compilation, are somewhat mythical, but they clearly depict relatively small communities. ${ }^{20}$ The first 
text pictures a very high proportion of mendicants (1-9.54 laity) and an overwhelming numerical dominance of female ascetics and lay supporters. The prevalence of nuns is all the more remarkable, because, until very recently, neither Buddhist nor Hindu monastic orders had significant, if any, numbers of female ascetics. Even today, Theravāda Buddhist orders in Sri Lanka, Thailand, Burma and Laos do not have fully initiated bhikkunis. ${ }^{21}$ The second account contains a list of the succession after Mahāvīra, which is corroborated by epigraphical evidence. ${ }^{22}$ It mentions only the names of 7 nuns amongst a total of 19 disciples of Nandanabhadra, the seventh elder (thera) after Mahāvīra. ${ }^{23}$ The corresponding inscription of the first or second century CE, mentions 9 nuns, which Bühler (1890: 321) accepted as 'clear proof that in the first century of our own era the order of female ascetics was well established'.

At the beginning of the twentieth century most lay communities began to publish sporadic demographic information on the numbers of their monks and nuns in community newsletters. However, these newsletters had only a limited circulation. Readily available information on individual monastic communities remained largely inaccessible until the last two decades of the twentieth century, which saw a significant improvement. The person responsible for this is the Sthānakavāsī layman Bābūlāl 'Ujjavala' Jain of Mumbaī. Once an active member of the Akhil Bhāratīya Jain Mahāmaṇụal, the principal ecumenical forum of the Jain communalists ${ }^{24}$ founded in 1899 under the name Jain Young Men's Association but renamed in 1929, he began to compile and publish charts of the cāturmāsa residences of all the mendicants of the reformist Sthānakavāsi Sramana Sangha from 1979 onwards. The rational was to generate a sense of unity and coordination amongst the followers of the Śramana Sangha, which, although nominally governed by only one ācārya, is internally subdivided into many local mendicant traditions. The documentation proved to be useful in keeping track of the movements of the almost 1,000 mendicants, which from the time of the foundation of the Śramana Sangha in 1952 began to extend their vihäras from their traditional strongholds in western and northern India to the entire territory of the new independent state of India.

In 1984, B. U. Jain produced an extended version of the cāturmās list, now covering not only the Śramana Saṇgha, but all Sthānakavāsī ascetic and lay communities. In this he was supported by the Śramana Sangha muni Kanhaiyāāāl, the Mūrtipūjaka painnyās Haraṣ Sāgar, and the Akhil Bhāratiyā Samagra Jain Cāturmās Sūcī Prakāśan Parișad Bambaī. Finally, in 1986, the first annual Samagra Jain Cāturmāsi Sūcī was published with the intention of providing information on the cāturmās residencies of all Jain mendicants. ${ }^{25}$ This project was officially endorsed by the great assembly of the Sramana Sangha ascetics in Pune in 1987 (AISJC 1987: 19f., B. U. Jain 1987: 71). From this time onwards, the available demographic data of all Jain mendicant communities were published annually, first by the Cāturmās Sūcī Prakāśan Pariṣad 1986-1992, then by the Jain Ektā Mahāmaṇụal, and last by B. U. Jain himself (SJCS 1987: 67f.).

The following overview of the current divisions of the Jain mendicants, their numbers and main demographic shifts between 1987 and 2002 is to a significant 
extent based on the data compiled in B. U. Jain's Cāturmās Sūcī publications of 1987, 1990, 1996, 1999 and 2002. For want of reliable information, I was not always able to shed light on earlier demographic developments. To my knowledge, only the Śvetāmbara Terā Panth has published complete demographic and biodata going back to the time of its foundation in 1760 (Navratnamal 1981ff.). I was able to locate some useful material on the numbers of Sthānakavāsī mendicants in the early twentieth century, but little on the Mūrtipūjaka and Digambara ascetics. In these instances I had to rely on sporadic information scattered in the secondary literature.

I have rearranged B. U. Jain's data on the Śvetāmbara mendicant orders into a number of tables summarising figures from 1987, 1990, and 1996, with additional information from 1999 and 2002 provided either in the text or in supplementary tables or footnotes. Initially, the figures published by B. U. Jain were not reliable for non-Sthānakavāsī orders, but this has changed with regard to the Śvetambara orders. An important lacuna in B. U. Jain's publications is the lack of reliable information on the Digambara ascetics, on which no sound data existed until recently. I have nevertheless cited some of B. U. Jain's fragmentary and inconsistent figures on the Digambaras between 1986 and 2000, because they contribute significantly to our generally meagre knowledge on the Digambara mendicants, whose organisational history is reviewed in greater detail in this chapter. From the year 2000 onwards, reliable information on the Digambara mendicants and cāturmāsa places is published annually by A. Jain (2000a, 2000b, 2001) of Indore in form of a brochure which together with D. Sāstrī's (1985) Digambara Jain Sādhu Paricay is the main source on the demography of the Digambara ascetics.

The figures in the available Jain publications rely on credible self-reporting by the different Jain orders. The quality of this data, especially from the Mūrtipūjaka traditions, varies from year to year. In order to compensate for this, B. U. Jain included personal estimates in his summary tables to account for those ascetics for whom no detailed information was supplied to him (B. U. Jain 1996: 37, 27f., n. 1-2, 1999: 382, n. 1-7). By contrast, I only counted those ascetics which were listed individually and not B. U. Jain's considerably higher estimates, which may nevertheless represent a more accurate picture. Another difference concerns the classification of mendicant orders into broader categories. From 1990, B. U. Jain re-classified certain reformist movements, such as Amar Muni's Vīrāyatan, Muni Suśîl Kumār's Arhat Sangha and the Nava Terā Panth, under the new category 'independently roaming progressive thinkers who use vehicles' (pragatiśīl vicārak vāhan vihārī svatantra vicaran karne vāle). But I continued listing them together with their traditions of origin. A major deficit of the publications of B. U. Jain and A. Jain is the lack of statistical data on the social background of the ascetics, especially on caste, class and region, their initiation age and level of formal education. They also offer no overview of the history and organisation of the mendicant groups. As far as possible, I have supplemented this information from other sources. 
In the following tables, the àcarryas are also included in the total numbers of $s \bar{a} d h u s$. A hyphen indicates that no information is available or means zero. The data is neither complete nor entirely consistent. But, in general, it is reliable and provides the most accurate available information to date.

\section{Mūrtipūjaka}

The Mūrtipūjaka mendicants are currently divided into six independent traditions, which emerged between the eleventh and the sixteenth century CE from the caityavāsin, or temple-dwelling, Śvetāmbara tradition: ${ }^{26}$ (1) the Kharatara Gaccha (1023), (2) the A(ñ)cala Gaccha or Vidhi Pakșa (1156), (3) the Āgamika- or Tristuti Gaccha (1193) and (4) the Tapā Gaccha (1228), from which (5) the Vimala Gaccha (1495), and (6) the Pārśvacandra Gaccha (1515) separated. ${ }^{27}$ The two main reasons for these so-called gaccha-reforms were (a) the laxity of the caityavāsins, and (b) minor doctrinal differences. Similar reforms within the gacchas in the seventeenth century led to the division between yatis and samvegi $s \bar{a} d h u s$. The term samivegī, upright, was introduced by Upādhyāya Yaśo Vijay (1624-1688) for his own reformist mendicant group, whose tradition was revived in the nineteenth and early twentieth centuries, at a time when most of the previously dominant white-clad yatis were replaced by yellow-clad samivegī sādhus. Today, almost all Mūrtipūjaka mendicant groups are samvegī orders. With the exception of the Vallabhasūri Samudāya of the Tapā Gaccha, all reverted to wearing white dresses. The orders are independently organised and form the institutional core of distinct sects and schools. At present, no detailed sociological or demographic information is available for most of these monastic traditions, especially for the period before the twentieth century. Two notable exceptions are the studies of the recent history and organisation of the Tapā Gaccha by Cort (1989: 93-112) and of the A(ñ)cala Gaccha by Balbir (2003), both of which are supplemented by the studies of the pattâvalīs of both traditions by Sivprasād (2000, 2001). Of the Kharatara Gaccha only the pattāvali of its monastic order and contemporary religious practices of the laity have been studied (Laidlaw 1995, Babb 1996).

The Kharatara Gaccha and the A(ñ)cala Gaccha are the only Mūrtipūjaka traditions which still have a dual system of succession (paramparā) of yatis and samivegi $s \bar{a} d h u \mathrm{~s} ;{ }^{28}$ although there is only one yati left in the $\mathrm{A}(\tilde{\mathrm{n}})$ cala Gaccha (see Figures 12.1 and 12.2). ${ }^{29}$ The $s \bar{a} d h u$ s and $s \bar{a} d h v \bar{\imath}$ s of the A(ñ)cala Gaccha are nowadays centrally organised under the supervision of only one ācārya (gacchādhipati) and still ${ }^{30}$ constitute one of the largest mendicant orders of the Mūrtipūjaka tradition. ${ }^{31}$ By far the largest of the six Mūrtipūjaka gacchas is the Tapā Gaccha. According to Darśanavijaya (1933: 67, fn.), it had only 428 members at the end of the fifteenth century. By 2002 this figure had risen to 6,696. ${ }^{32}$ Today, the Tapā Gaccha is divided into two branches $(\dot{s} \bar{a} k h \bar{a})$, the Vijaya Śākhā and the Sāgara Śākhā. The śākhas are further subdivided into a number of lineages which 


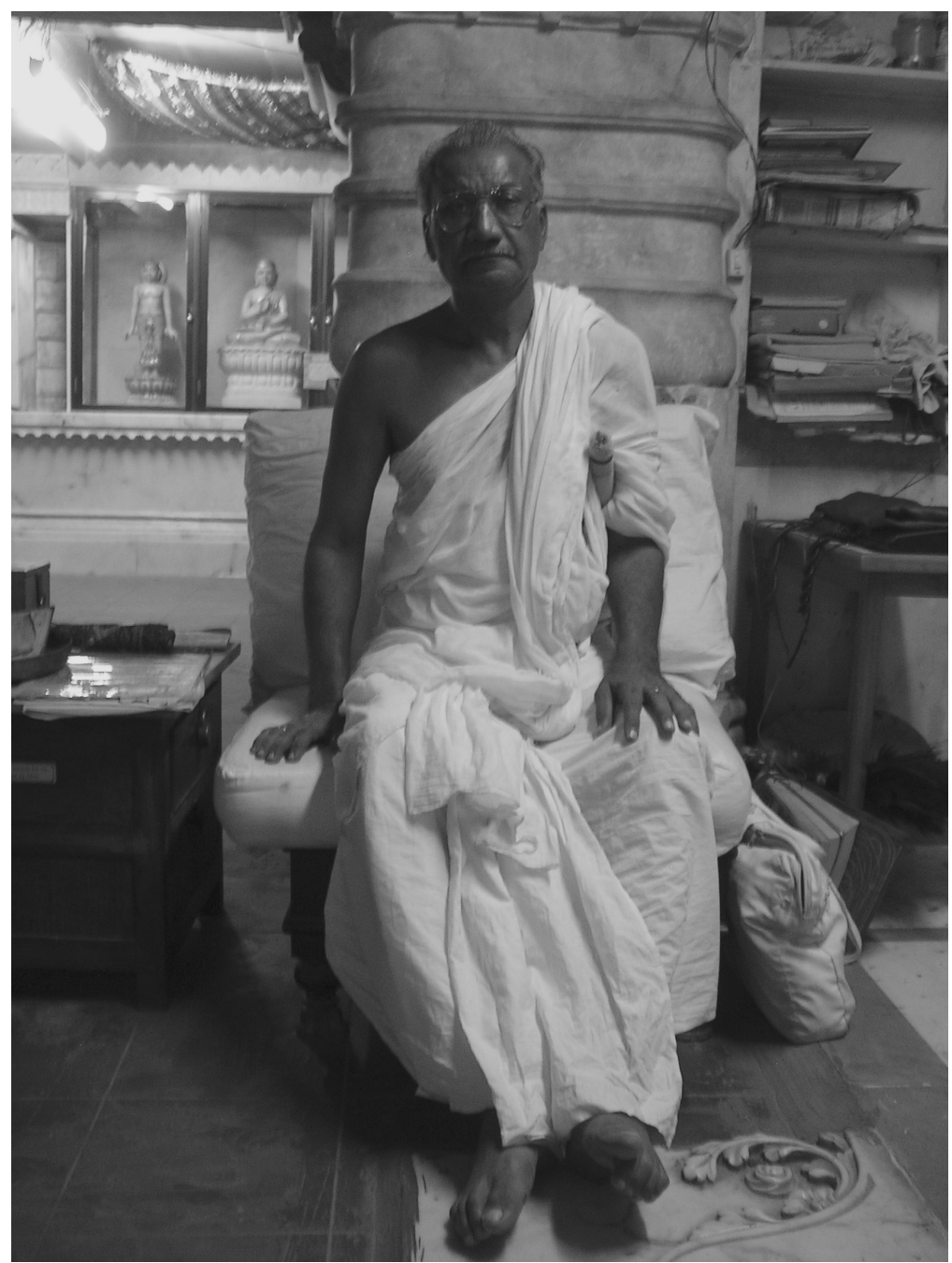

Figure 12.1 Yati Motī Sāgar of the A(ñ)cala Gaccha in Mumbaī. Photograph by the author, December 2004.

are currently divided in twenty separate groups, or samudāyas, which are named after prominent $\bar{a} c \bar{a} r y a$ s of their root lineage, with the $s \bar{a} d h v \bar{\imath} \mathrm{s}$ defined through the male members of the traditions (Cort 1991: 661f.). The origins of the Sāgara Śākhā are opaque. Kañcansāgarsūri et al. (1977: 311-76) attribute its beginnings to Hīra Vijaya Sūri (1527-1569), though Śāh $(1987: 14,65,168)$ points to the year 1630 in which Ācārya Rāj Sūri (formerly Muni Mukti Sāgar) seceded from the main line of the Tapā Gaccha with the help of the first nagarśeth 


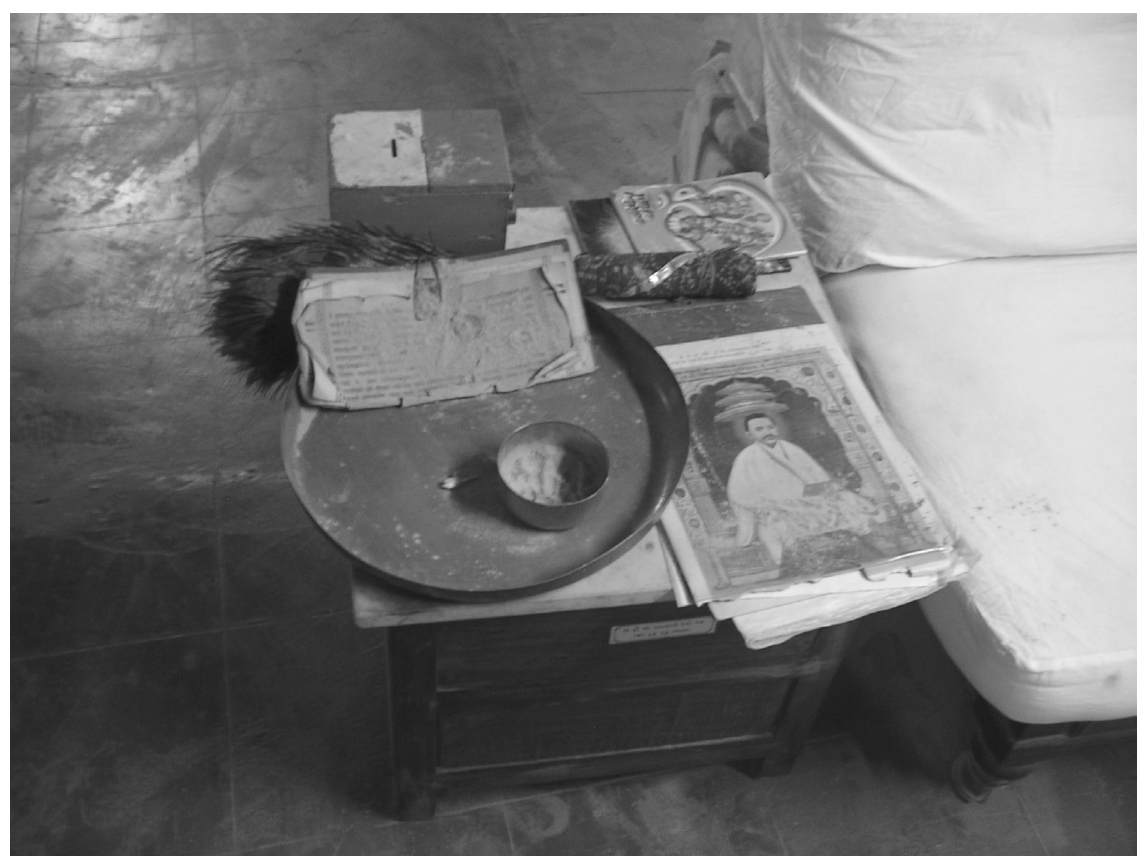

Figure 12.2 Paraphernalia of Yati Motī Sāgar. Photograph by the author in Mumbaī, December 2004.

of Ahmedabad, Śāntidās Jhaverī (1585/1590-1659); ${ }^{33}$ who in 1660 also sponsored the Ānandjī Kalyānjjī Trust. ${ }^{34}$ According to Dundas (1996: 101, n. 108), this tradition was disrupted in the eighteenth and nineteenth centuries. ${ }^{35}$ It was revived in the mid-nineteenth century by Mayā Sāgar with the help of Hemābhāī, another nagarśeth of Ahmedabad, and of Śeth Haṭīsinha Keśarībhāī (died 1845). ${ }^{36}$ After Mayā Sāgar, the tradition split into two samudāyas, the two most famous ācāryas of which were Buddhi Sāgar Sūri (1874-1925) and the 'Āgamoddhāraka' Sāgar Ānand Sūri (1875-1950) respectively. The Vijaya Śākhā emerged apparently in 1657, a date which roughly corresponds to Sāh's (1987) version of the origin of the Sāgar Sākhā, following a succession dispute after the death of Vijay Deva Sūri (1577-1656). ${ }^{37}$ In 1999, it was internally subdivided into twenty samudāyas.

Cort (1989) observed momentous changes within the Vijaya Sākhā over the last one and a half centuries, as narrated in the histories of the Tapā Gaccha orders by Ratna Prabha Vijay (1948) and others. First of all, the yatis, that is, sedentary ascetics who fulfil ritual and administrative tasks and who do not pledge themselves fully to the observance of the mahāvratas, became almost extinct in the twentieth century ${ }^{38}$ and were replaced by the reformed samveg $\bar{\imath}$ 
$s \bar{a} d h u$, of which apparently only two dozen or so existed in the early nineteenth century: ${ }^{39}$

In the mid-19th century, several activist sädhus reinvigorated the institution of the samvegi sādhu. Over two-thirds of the over 1,000 sād$h u$ s in the Tapā Gacch today trace their lineage back to Pañnyās Mani Vijay Gan̄ī (1796-1879), known as Dādā (Grandfather). One of his disciples was the former Sthānakvāsī sādhu Muni Buddhi Vijay (1807-1882), known by his Sthānakvāsī name of Buterāyjī. He was very active in the Panjab among both mendicants and laity, convincing Sthānakvāsīs of the correctness of the Mūrtipūjak teachings. Among his disciples was the charismatic Ātmārāmjī (1837-1896), who in 1876 in Ahmedabad took a second $d \bar{\imath} k s ̣ \bar{a}$ (initiation) as the Mūrtipūjak samvegī $s \bar{a} d h u$ Ānand Vijay, along with eighteen other Sthānakvāsī sādhus, under the leadership of Átmārāmjī and other similar minded sādhus, and later under the umbrella of the Śvetāmbar Mūrtipūjak Conference, a wide-ranging campaign was waged to reform both mendicant and lay practices. As the result of this reform the institution of the yati has virtually disappeared from the Mūrtipūjak society.

(Cort 1989: 99f.)

Cort showed that after the disintegration of the gaddi-centred yati-orders, new decentred patterns emerged, based on demographics, geography and charisma rather than on organisational power and property. It is worthwhile quoting him again at length:

As the Tapā Gacch has grown, it has subdivided in new ways which shed light on earlier processes of subdivision and gacch formation. The former subdivisions, which were based primarily on affiliation with the $g \bar{a} d \bar{l}$ s (seats, thrones) of specific śrippüjyas, have disappeared, with the exception of the Vijay-Sāgar śākhā distinction, and been replaced by about 15 samudāys (literally 'co-arising', i.e. descendants of the same $s \bar{a} d h u$; here synonymous with sampradāy). In general, three interrelated principles accounted for the development of the various samudāys: geography, demographics, and charisma. As the number of $s \bar{a} d h u$ s increased, it became increasingly difficult for one $\bar{a} c \bar{r} r y a$ to oversee the large number of sādhus under him. Smaller groups of $s \bar{a} d h u$ s were placed under the direction of other senior $s \bar{a} d h u s$, and the sharp increase in the number of the $\bar{a} c \bar{a} r y a$ s within the Tapā Gacch in the past several years is directly related to this need for additional supervisory personnel. As the $s \bar{a} d h u$ s increasingly interacted solely with the lesser $\bar{a} c \bar{a} r y a$ rather than the seniormost $\bar{a} c \bar{a} r y a$, a new samudāy might evolve.

(Cort 1989: 103f.) 
According to Jacobi (in Glasenapp 1925: 342, 352-354), the Tapā Gaccha was in 1913-1914 still ruled by 'a number' of śrīpūjyas and, as a whole, comprised 1,200 sā $d h u$ s and $s \bar{a} d h v \bar{\imath} \mathrm{s} .{ }^{40}$ Guérinot (1926: 56) reported the existence of ' 30 subdivisions' of the Tapā Gaccha at the beginning of the twentieth century, without mentioning any figures, while B. U. Jain (1986) and Cort (1989: 100-105) found only two śákhās and altogether 15-17 autonomous groups (samudāya). Table 12.1 shows that by 1999 this figure had grown to twenty due to further splits in the dominant Vijaya Sákhā tradition of Prem Sūri, the latest being the separation of Kamal Ratna Sūri from the Rāmacandrasūri Samudāya in 1998. Prem Sūri was one of the chief disciples of Buddhi Vijay, the reformer of the samvegi sādhus, together with Ātmā Rām, Dharma Vijay (1868-1922) and Nīti Sūri (whose lineage further split into the Bhaktisūi- and the Siddhīsūri Samudāya) (Ratna Prabha Viyay 5, 2 1948: 218). At present, four samudàyas trace themselves back to Prem Sūri: the Rāmacandrasūri Samudāya, the Kamalaratnasūri Samudāya, the Bhuvanabhānusūri Samudāya and the Amṛtasūri Samudāya. Four samudāyas descend directly from Ātmā Rām (Vijay Ānand), the most famous disciple of Buddhi Vijay: the Vallabhasūri Samudāya, the Mohanalāla Samudāya, the Dharmasūri Samudāya and the Sānticandrasūri Samudāya. The Rāmacandrasūri Samudāya is the only group which advocates the be tithi interpretation of the religious calendar, ${ }^{41}$ and has therefore been excluded from many Tapā Gaccha upāśrayas. Table 12.1 does not include detailed figures for 1986 (cf. Cort 1989: 491f.), 1999 and 2002, which are appended in the endnotes. But it reflects the group structure of 1999 and shows that at the time the Mūrtipūjaka tradition was divided into some twenty-seven independent monastic groups.

In 1999, the Mūrtipūjaka gacchas comprised altogether 6,843 mendicants, 1,489 sādhus and 5,354 sādhvīs. Amongst them, the Tapā Gaccha was the largest tradition, with 6,027 mendicants, 1,349 sādhus and 4,678 sādhvīs. ${ }^{42}$ The table shows a massive increase in numbers particularly of female ascetics within little more than a decade. ${ }^{43}$ It also illustrates the fact, emphasised by Cort (1989: 494, 1991: 661), that occasionally significant population shifts occur within and between samudāyas, which - in the absence of centralised gaddī-structures seem to divide and unite like segmentary lineages, under the influence of circumstantial factors. Similar changes cannot be observed at the level of the gaccha categories. ${ }^{44}$ Commensality between ascetics of different gacchas is, for instance, prohibited..$^{45}$ Schubring (2000: $§ 139$, p. 252) already noted that gacchas are not necessarily actual groups. Mūrtipūjaka gacchas are in the first place doctrinal schools and at the same time social categories which may or may not be congruent with organised monastic groups, such as the samudāyas. However, doctrinal disputes are also significant for processes of group-formation at the samudāya level. A good example is the ek tithi/be tithi dispute between Rām Candra Sūri and Bhuvan Bhānu Sūri, which split the Premsūri Samudāya into two main sections in 1986 (Cort 1999: 50f.).

Another important factor influencing processes of fission and fusion are the ways in which gacchas and samudāyas are organised. Shāntā (1985: 329-331) and 


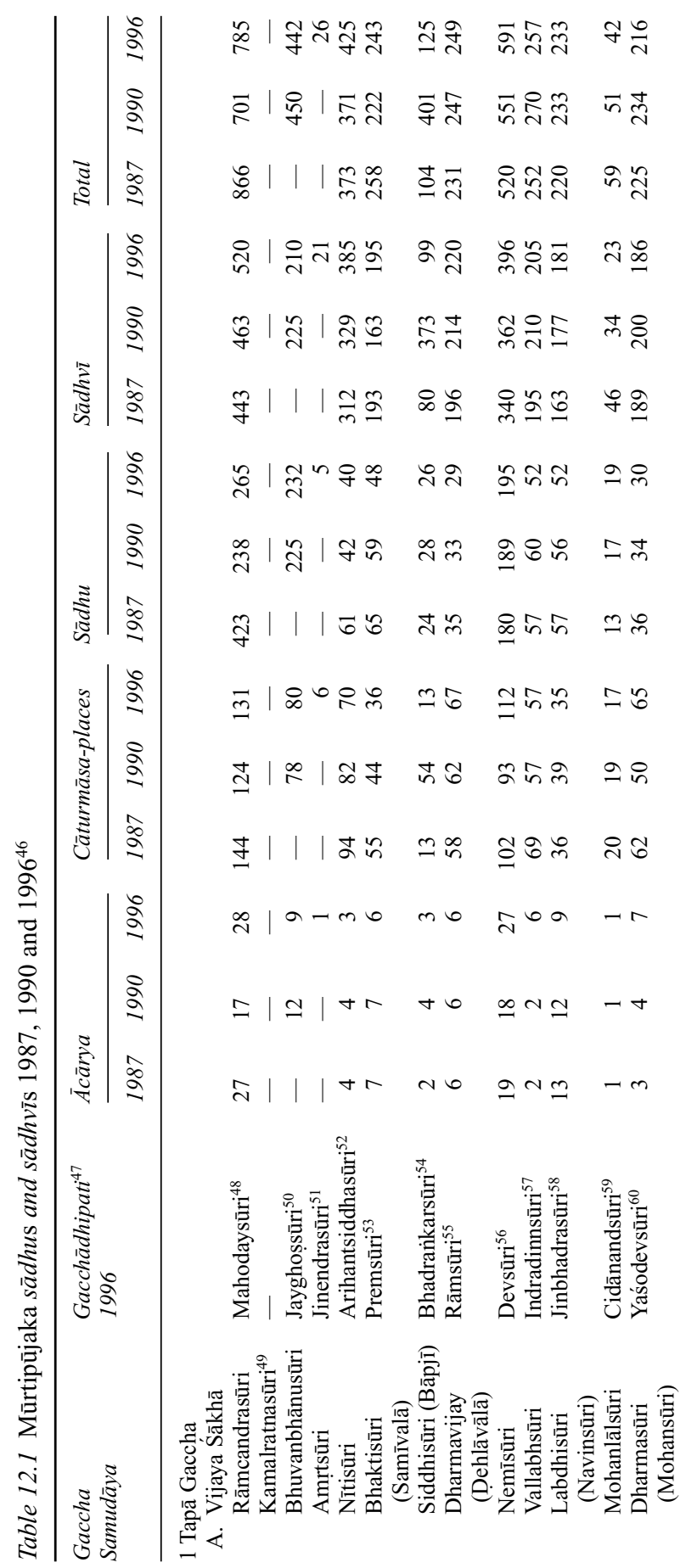




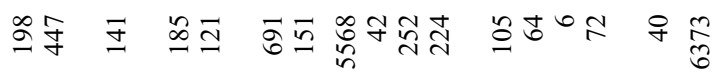

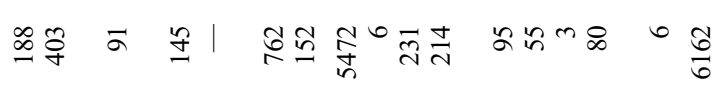

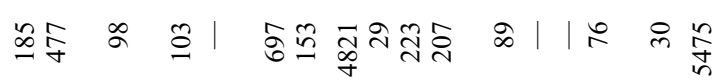

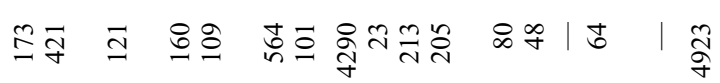

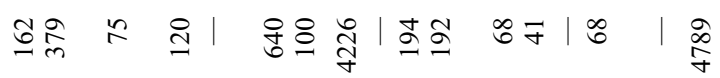

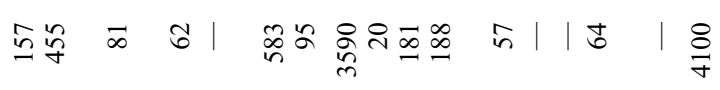

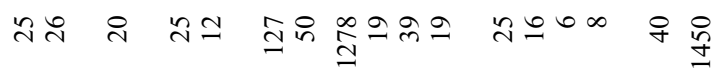
经

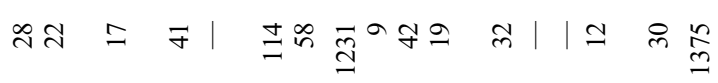

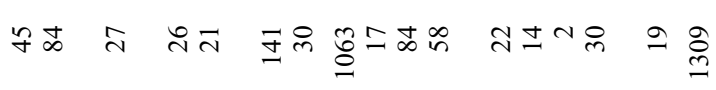
₹ล 梅

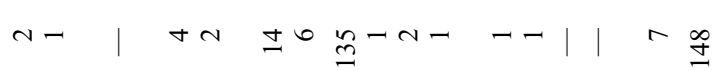
$m--\infty, 00 \cong-n-\cdots,-\infty$

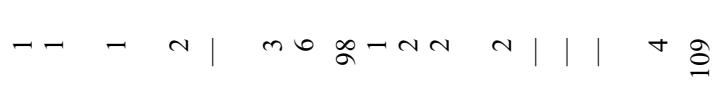

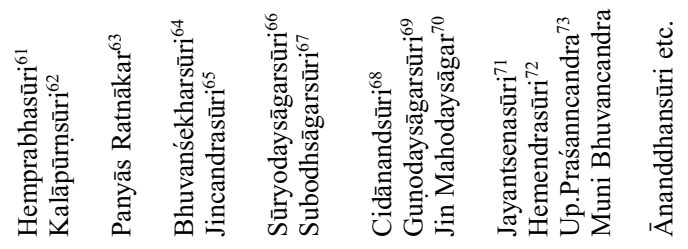

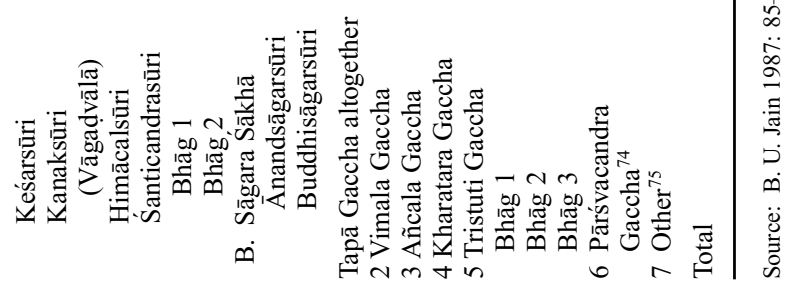


Cort (1991) explain population shifts and processes of group segmentation amongst the Tapā Gaccha samudāyas mainly with reference to charismatic leadership. Cort emphasises, for instance, the effect of the unusually high numbers of $\bar{a} c \bar{r} r y a \mathrm{~s}$ on the processes of segmentation and the size of Tapa Gaccha samudāyas. He explains this effect both with 'internal organisational pressures for the growth of the number of Tapā Gacch ācāryas - a growth which has been criticised by many sādhus and laity' and with 'the desire of influential laity to have the $s \bar{a} d h u$ of whom they are a personal devotee be an àcārya' (ibid.: 668, n. 16). But he also notes that a distinction between 'charismatic' samvegī sādhus and 'domesticated' yatis is not exactly applicable, since even the samivegi sādhus have a succession of leaders and thus are not 'purely charismatic figures in the Weberian sense' (ibid.: 669, n. 22). Weber (1978) himself categorised Jain monastic orders not as charismatic movements but primarily as 'hierocratic organisations'. ${ }^{76}$

Although some samudāyas share the same customary law (maryādā) ${ }^{77}$ Tapā Gaccha samudāyas are generally organised independently, and compete with one another, even within their śākhās. As a rule, members of one samudāya do not share food with those of another (personal invitations notwithstanding). ${ }^{78}$ Each samudāya is governed by a gacchādhipati or pramukhā ācārya, head teacher, who is generally determined according to monastic age (dīkșa paryāya) or by consenus, except in the Rāmacandrasūri Samudāya, where the gacchādhipati ideally selects his own successor. ${ }^{79}$ The gacchādhipati presides over a varying number of monastic functionaries, including subordinate $\bar{a} c \bar{a} r y a$ s with or without administrative duties, who received their title solely because of their academic achievements. $^{80}$

I suspect that the maximum size of Jain monastic groups is primarily a function of their rules and regulations, which mediate between the categories of descent and the imperatives of group integration (Flügel 2003b: 191ff.). ${ }^{81}$ Circumstantial factors such as the socio-economic resources of a particular religio-geographic field (ksetra) or charismatic leadership are important in specific cases, particularly on the level of gatherings. But generally, the degree of organisation determines its chances of reproduction over time, the maximum group size and thus the potential geographic influence of a particular monastic order. To put it simply, the better the organisation of a group, the greater its potential size and the greater its size, the greater its potential influence. The three principal dimensions of Śvetāmbara monastic orders are descent, succession and seniority. They can be combined in various ways to produce different types of organisation.

In theory, it should be possible to develop a formula for calculating the ability of different types of organisation to compensate for demographic pressure. Practically, there is an upper limit for the size of groups without formal organisation based solely on the principle of recurrent personal interaction. As a first approximation, the breaking point leading to group fission within the orders of the Vijaya Śākhā can be estimated through simple averages. In 1996, the average group size of the smallest organised units of the Tapā Gaccha samudāyas, the 
itinerant groups or sainghadās, gatherings, was 5.24 at cāturmāsa. This figure is not unusual for Śvetāmbara orders. It reflects both religious rules on minimal group sizes as well as socio-economic factors, such as the number and wealth of lay-supporters. Evidently, a large group of alms-collecting ascetics can only stay together at one particular place if provisions are available and if their procurement is carefully organised (with the help of the laity).

Within the Mūrtipūjaka tradition, as a rule, the sanghadās have a fluctuating membership. They comprise the members of one or more categories of ascetics who belong to the lineage of one particular ācārya. These are called parivāras, or families, and are composed of both sādhus and sādhvīs. The parivāras are co-ordinated by one pramukha ācārya, who is the leader of a gaccha or a samudāya. The majority of the ācäryas have no administrative duties, although this varies from group to group, but they possess the qualification for the transformation of their parivāras into independent groups. In 1996, the actual average size of a Tapā Gaccha samudāya was 278.4 ascetics, distributed, on average, among 53.13 itinerant groups. However, the number of Tapā Gaccha ascetics divided among the total number of $\bar{a} c \bar{a} r y a$ is 41.24 , which represented theoretically the lowest average limit of potential group fission between Tapā Gaccha ācāryas in 1996. The difference between average actual group sizes and potentially lowest average group size demonstrates the importance of other organisational factors determining group size. But in order to understand, for instance, how the 447 ascetics under the sole leadership of Ācārya Kalāpūrn Sūri of the Kanakasūri Samudāya operate as an integral monastic order, further historical and ethnographic research is required. Segmentary lineages can temporarily form very large groups. Nevertheless, it seems that samudāyas of such a size are not merely segmentary lineages, but internally highly organised, and divided into subgroups whose membership is not based on descent alone. ${ }^{82}$ That the Tapā Gaccha samudāyas form distinct monastic orders, whose members share specific rules and regulations (marya $\bar{a} \bar{a}$ ), is evident for instance in the explicit prohibition of sharing meals with members of other samudayas. ${ }^{83}$ In fact, most Jain mendicant groups operate on the basis of an internal administrative hierarchy and a rudimentary division of labour. However, further statistical investigation of the correlation of group size and group structure becomes only meaningful if more information on organisational structures and other important variables is available. Complete data and careful theoretical modelling might, in future, lead to reliable predictions of expected group sizes under specified conditions.

\section{Sthānakavāsī}

The Sthānakavāsī mendicants are presently divided into twenty six monastic orders. These can be classified according to regional affiliation, doctrinal schools and the lineages descending from one of the five founders of the contemporary traditions, the so-called pañcmuni. ${ }^{84}$ Three of these founders separated themselves from the now virtually extinct Lonkā Gaccha yati traditions to set up reformed ascetic orders within the aniconic, or non-image worshipping, Jain tradition which originated 
between 1473 and 1476 after the 'protestant' reforms of the Jain layman Lonkā (c.1415-1489) in Gujarāt: ${ }^{85}$ (1) Jīv Rāj (seceded 1551, 1609 or 1629), who apparently canonised the thirty two Śvetāmbara scriptures that are acceptable to the Sthānakavāsīs, established the permanent use of a mouthmask (muhapattī), and other principal features shared by all modern-day Sthānakavāsī traditions; (2) Dharma Sinha (seceded 1628, 1635 or 1644) and (3) Lava (seceded 1637, 1648, 1653-1655 or 1657). Dharma Sinha was the founder of the Âth Koti (eighth grade) traditions ${ }^{86}$ and Lava the founder of the Dhūndiyā traditions, which are also known under the name Rụi Sampradāya. (4) The founder of the Bāis Tolā traditions, Dharma Dāsa (seceded 1659, 1560, 1564 or 1665), was originally a member of the lay order of the Ekala Pātriyā Panth and maybe a follower of Jīv Rāj shortly before Jīv Rāj's death; and (5) Hara (seceded 1668 or 1728), the ancestor of the Sādhu Mārgī traditions, divorced himself either from the Lahaurī Lonkā Gaccha or from the R̦̣i Sampradāya.

Doctrinally, Dharma Sinha's Âth Koṭi tradition differs significantly from the other four schools, which disagree only on minor points of interpretation. It is today represented by the Dariyāpūri tradition in Gujarāt and by the two Āth Koṭi traditions in Kacch, one of which - the Nānā Pakṣ - is very orthodox. The other Sthānakavāsī traditions are divided along regional lines between the Gujarātī and the non-Gujarātī (North Indian) traditions. The non-Gujarātī traditions are further subdivided into those who joined the reformist Śramana Sangha, which was founded in 1952 in a merely partially successful attempt to unite all Sthānakavāsī groups, and those who remained outside or left the Śramana Sangha. Both the centralised Śramana Sangha and the independent traditions include ascetics from four of the five main Sthānakavāsī traditions which were split into thirty three different organised groups at the beginning of the twentieth century (excluding only the Āth Koṭi traditions).

I have written elsewhere on the history and organisation of the aniconic Lonkā, Sthānakavāsī- and Terā Panth Śvetāmbara traditions. ${ }^{87}$ Therefore, I confine myself here to the description of their principal demographic features. Like the Jain Śvetāmbara conference of the Mūrtipūjaka laity, the second All India Sthānakavāsī Jain Conference in Ajmer in 1909 resolved to increase the educational standard and the total number of Sthānakavāsī ācāryas in order to raise the competitiveness of the Sthānakavāsīs vis-à-vis other Jain traditions (AISJC 1988 II: 8-32). In 1933 in Ajmer, the first assembly of representatives of all the Sthānakavāsī monastic orders decided to unify all traditions under the leadership of one ācārya. Finally, the Śramana Sangha was created by 22 out of the 30 traditions present at the assembly in 1952 in Sādaṛi in Rājasthān. Table 12.2 shows the regional distribution and the number of ascetics of the Sramana Sangha, which is now the largest organised group amongst the Sthānakavāsī mendicants, from 1987-1996.

Although they are nominally under the command of one single àcārya (at present: Dr Siv Muni), the remaining founding traditions continue to operate within the Śramana Sangha more or less independently. The official statistics therefore do not tell the whole story. Some mendicant orders never joined the Śramana Sañgha: for instance, the Jñāna Gaccha. And because of perpetual discord 


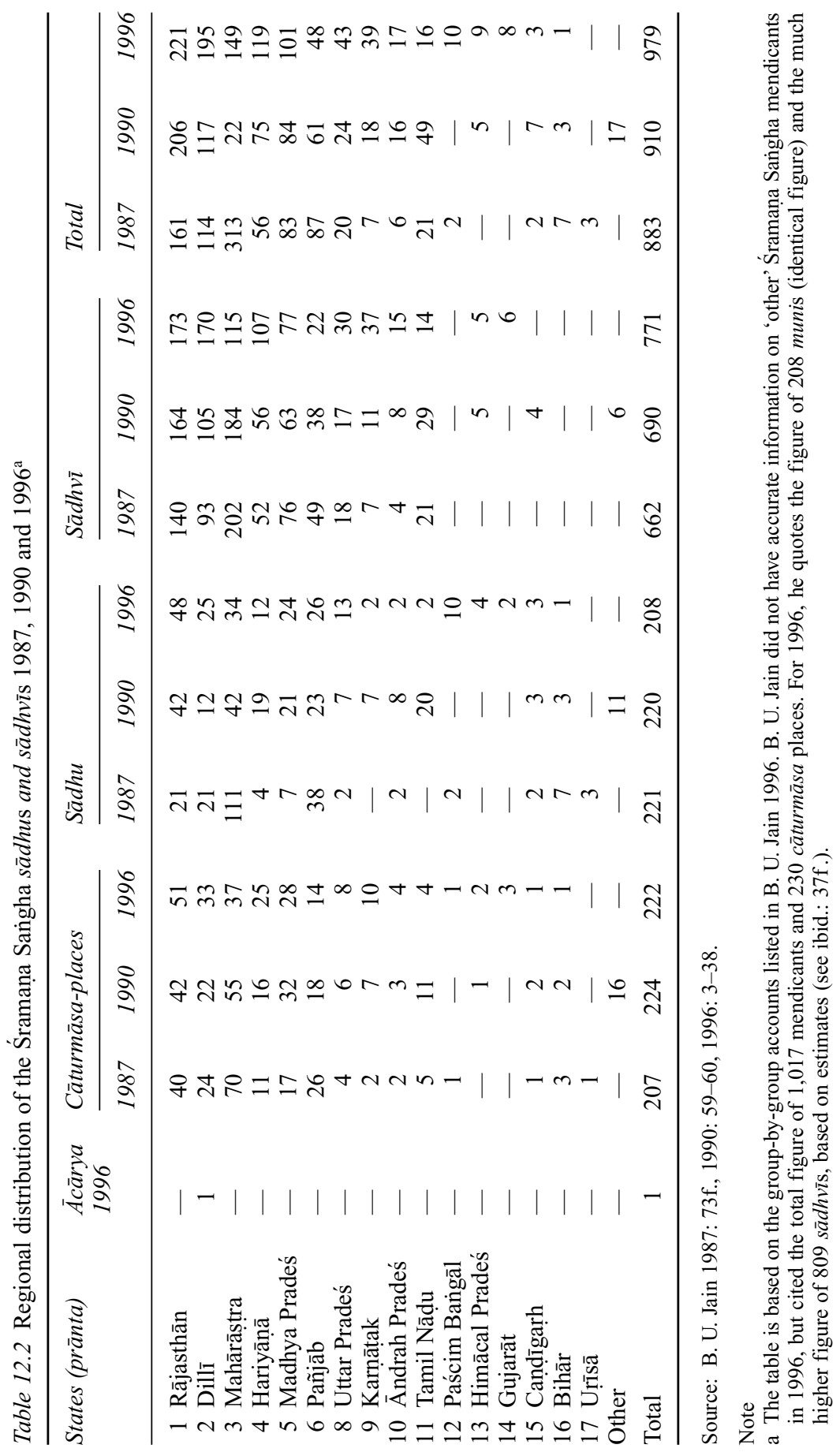




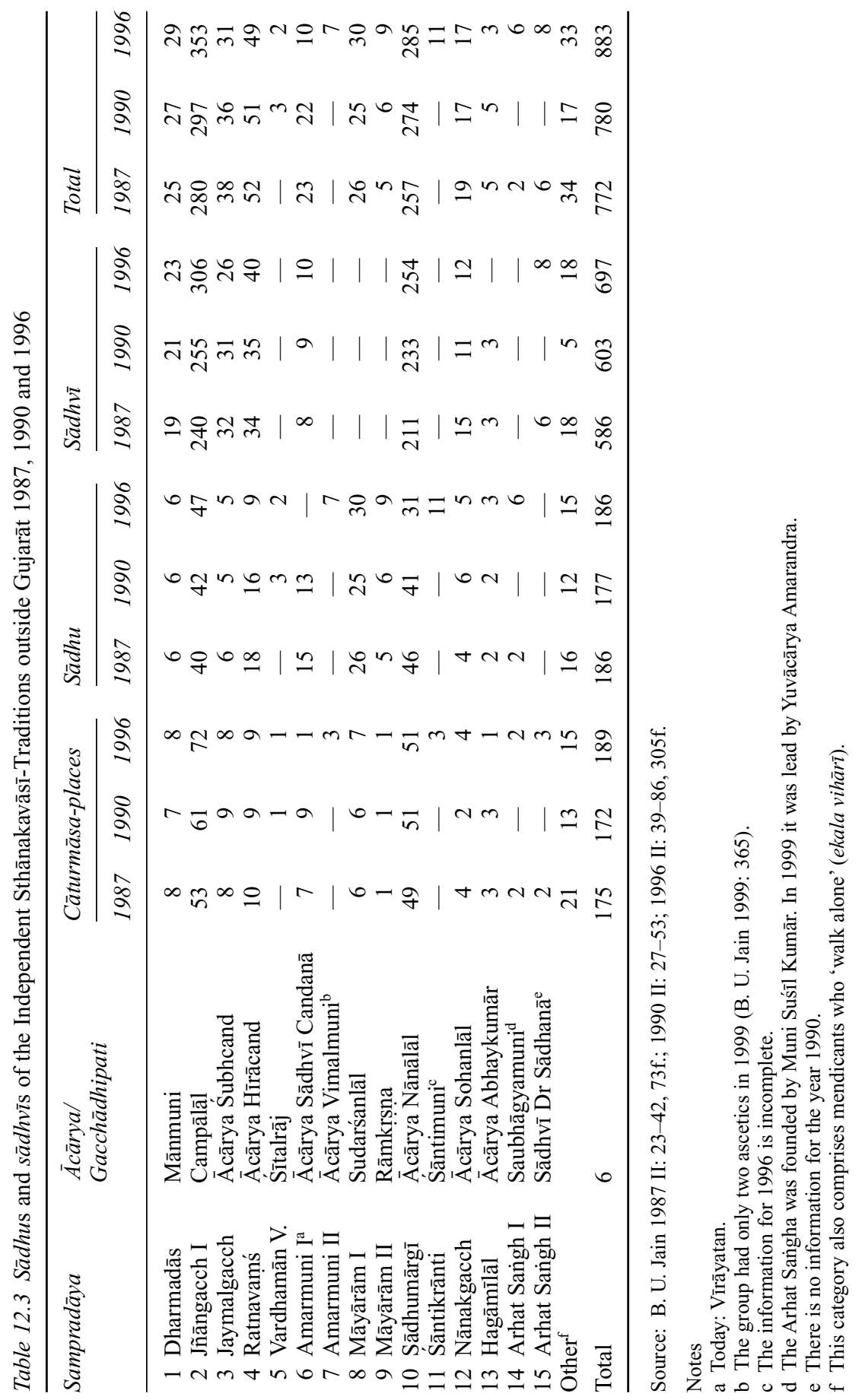




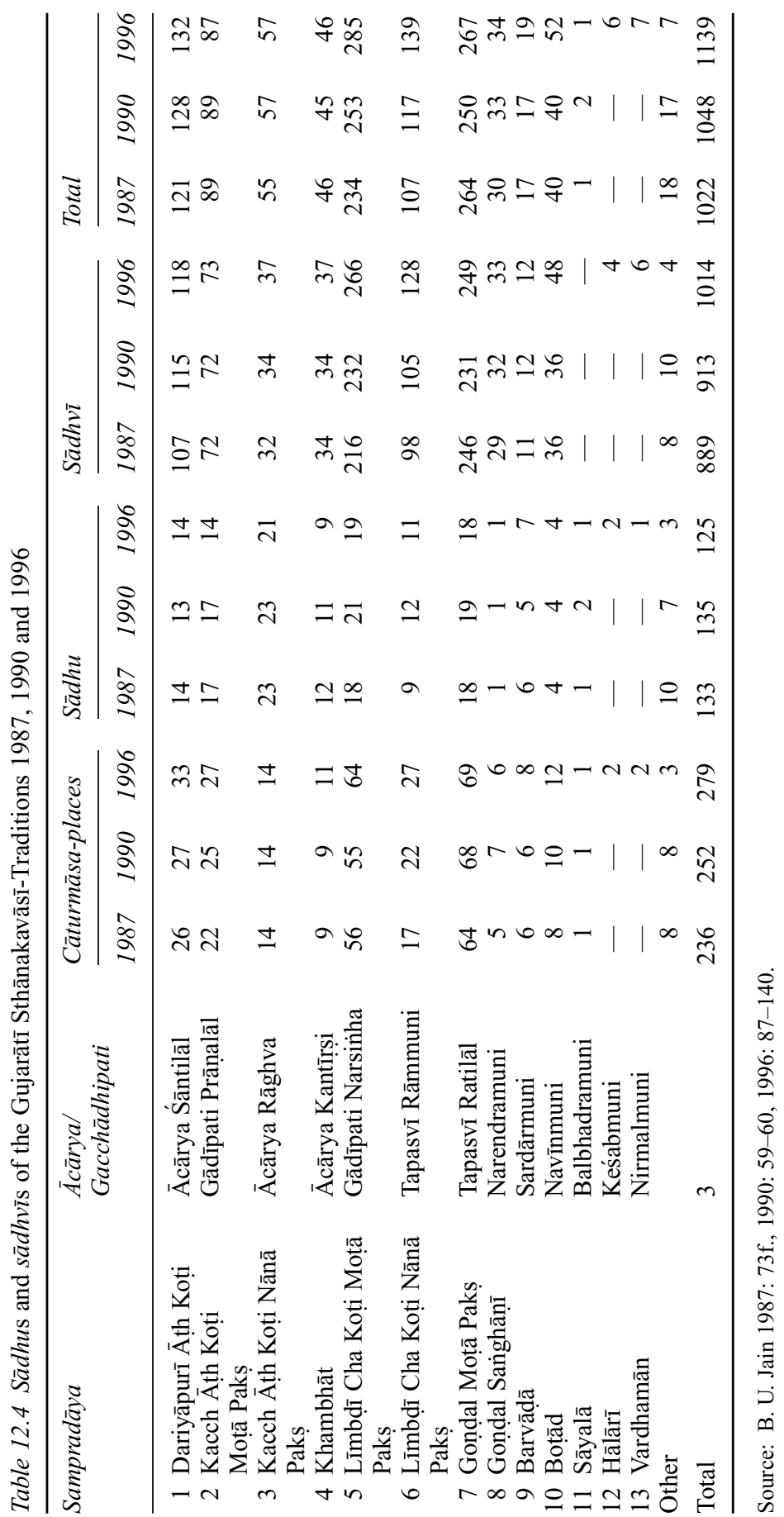




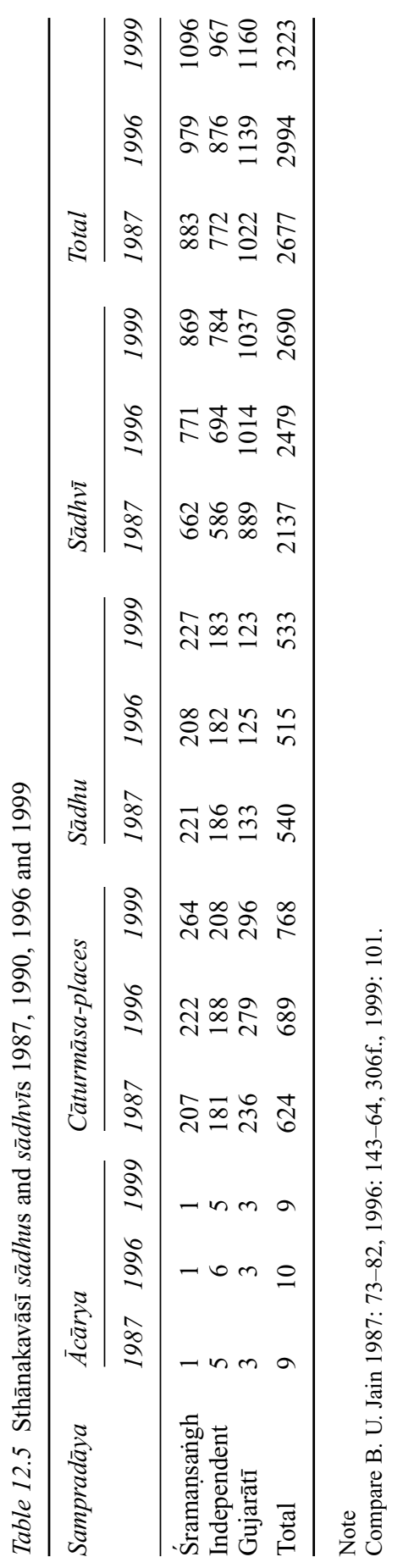


between the founding traditions, many disappointed ascetics, such as Upācārya Ganeśīiāl (1890-1963) of the Sādhu Mārgī or Upādhyāya Amar Muni (1901-1992) of the Manoharadāsa Dharmadāsa tradition, subsequently left the Śramaṇa Sangha and re-established their own independent groups. Moreover, in May 2003 the Śramana Sangha split into two groups, one of which is nominally presided over by the orthodox Pravartaka Umeś Muni, who has however not officially accepted the $\bar{a} c \bar{a} r y a$ title in order to avoid further conflict. Table 12.3 shows the independent Sthānakavāsī groups outside Gujarāt (for details see Flügel 2003b).

The majority of the Sthānakavāsī traditions in Gujarāt, listed in Table 12.4, descend from Dharma Dāsa and separated themselves in the years after 1788 from the Līmbḍi Dharmadāsa Sampradāya (Chah Koṭi Motāa Pakṣa). The only surviving Rṣi Sampradāya in Gujarāt, the Khambhāt Sampradāya, and the Āth Koti traditions restrict their activities to Gujarāt and Mumbaī. None of these Gujarātī groups joined the Śramaña Sangha, which is a Hindī-speaking order or association. They are usually not lead by a selected head, like the independent traditions outside Gujarāt, but by the monk with the highest monastic age, or $d \bar{\imath} k s \underline{a}$ paryāya, who may or may not be called ācārya.

The overall number of Sthānakavāsī mendicants is much higher than generally assumed ${ }^{88}$ At the time of the first All India Sthānakavāsī Sramaṇa Sammelan in Ajmer, the total number of mendicants of the then 30 Sthānakavāsī traditions was 1,595, $463 s \bar{a} d h u$ s and 1,132 sādhvīs (Manilāl 1934: 263). This figure had more than doubled by 1999 to altogether 3,223 mendicants, 533 sādhus and 2,690 $s \bar{a} d h v \bar{\imath} \mathrm{s}$, and by the year 2002 had increased further to altogether 3,331 mendicants, 559 sādhus and 2,772 sādhvīs ${ }^{89}$ In the sixty-six years between 1933 and 1999 the total number of Sthānakavāsī ascetics grew by $102.07 \%$. However, the number of $s \bar{a} d h u$ increased merely by $15.19 \%$, while the number of $s \bar{a} d h v \bar{\imath} \mathrm{s}$ expanded by a staggering $137.63 \%$, increasing their share by $12.48 \%$ from $70.97 \%$ to $83.46 \%$. Table 12.5 shows that the total number of Sthānakavāsī mendicants grew from $1987-1999$ by $20.40 \%$. All this growth was generated by an accelerated increase in the number of Sthānakavāsī sādhvīs during the last 12 years. At the same time, the absolute number of $s \bar{a} d h u$ s slightly declined.

The overall growth rate in 1987-1999 was almost twice as high in the Śramana Sangha and the independent orders than in Gujarāt (Śramaṇa Sangha 24.12\%, Independent $25.26 \%$, Gujarātī $13.5 \%$ ). This can partly be explained by the fact that in 1987 the percentage of $s \bar{a} d h v \bar{\imath}$ s was already particularly high in Gujarāt (1999: Gujarāt 89.39\%, Sramaṇa Sañgha 79.29\%, Independent 81.08\%). While the overall share of the $s \bar{a} d h v \bar{\imath} \mathrm{s}$ increased by $3.63 \%$, their growth was higher outside Gujarāt (Śramaṇa Sañgha 4.32\%, Independent 5.17\%, Gujarātī 2.4\%). It is difficult to say why Gujarātî traditions have a larger percentage of $s \bar{a} d h v \bar{\imath} \mathrm{s}$ in the absence of detailed historical studies. It is not inconceivable that initiations were artificially increased in Gujarāt; since already in 1933, at the Ajmer sammelan, an inconclusive debate was held amongst leading monks of the Sthānakavāsīs about a proposal to deliberately increase the number of disciples (Devendramuni 2000: 20). 
B. U. Jain does not supply any information on the biodata and on the social background of the mendicants. According to Bordiyā (in Shāntā 1985: 336f.), $30 \%$ of the Sthānakavāsī $s \bar{a} d h v \bar{\imath}$ s were widows in $1975,16 \%$ married and 53\% unmarried. The average age of initiation was 10-20 years. Most of the Sthānakavāsī ascetics stem from the Osvāl and Śrīmālī castes in Gujarāt, Rājasthān, Madhya Pradeś, Mahārāștra and Pañjāb, but also from southern India (Shāntā 1985: 333). In contrast to many other Sthānakavāsī traditions, the Śramaṇa Sangha comprises a large number of mendicants recruited from non-Jain castes such as Rājputs, Brāhmaṇas, or Jats particularly in the Pañjāb, while the lay following is almost entirely composed of members of the Osvāl castes, who are almost all Jain by religion. However, by convention, only an Osvāl can become $\bar{a} c \bar{a} r y a .^{90}$ Like most orders, the Sramana Sangha has banned the initiation of children below the age of 8 ( $b \bar{a} l a d \bar{i} k s \bar{a})$ and of old people ( $v r d d h a)$ (AISJC 1987: 52). ${ }^{91}$ However, the Jñāna Gaccha ${ }^{92}$ and the Dariyāpurī Sampradāy set a minumum age of 15 years. ${ }^{93}$

The two largest schools amongst the five principal Sthānakavāsī traditions are at the moment the Bāīs Tolā (Dharmadāsa) and the Lavjīṛsi tradition. Maṇilāl (1934: 211, 233) mentions that before its internal division in 1788, the Mūlacandra Dharmadāsa tradition in Gujarāt comprised about 300 mendicants. In 1933 it had not much more than 334 mendicants. If the figure for 1788 is correct, then little growth occurred in the 150 years between 1788 and $1933 .{ }^{94}$

Groups of more than 100 mendicants are rarely reported before the twentieth century. This may be due to the fact that no reliable figures are available before the nineteenth century, which had generally lower numbers of Jain ascetics than the twentieth century. In 1933, the six largest organised mendicant orders (sainghārā or sainghā $\dot{d} \bar{a}$ ) were the Amarasinha Lavjīṛși Sampradāya in the Pañjāb (133 mendicants: $73 s \bar{a} d h u s$ and $60 s \bar{a} d h v \bar{\imath} \mathrm{s}$ ), the Amolakaṛsi Lavjị̣̄si Sampradāya in Mālvā (105 mendicants: $24 s \bar{a} d h u$ s and $81 s \bar{a} d h v \bar{\imath} \mathrm{s})$, the orthodox Rāmaratna Dharmadāsa Jñāna Gaccha in Rājasthān (118 mendicants: 13 sādhus and $105 s \bar{a} d h v \bar{\imath}$ ), the Jayamala Gaccha of the Bāīs Tolā tradition in Rājasthān (103 mendicants: 13 sādhus and 99 sādhvī̄s), the Līmbdị Moțā Pakṣa of the Bāīs Tolā tradition in Gujarāt (94 mendicants: 28 sādhus and 66 sādhvīs), and the Goṇụal Moṭā Pakṣa of the Bāīs Tolā tradition in Gujarāt (86 mendicants: 20 sādhus and 66 sādhvīs) (Maṇilāl 1934: 211-262).

A closer look at the gender composition of the mendicant groups in 1933 shows that, with the remarkable exception of the Amarasinha tradition and certain subgroups within the Sramana Sangha, all traditions with more than ten mendicants tended to have many more $s \bar{a} d h v \bar{s}$ s than $s \bar{a} d h u$ s (generally at the rate of 3:1). It also becomes clear that small groups, such as the Manoharadāsa tradition $(7 s \bar{a} d h u s)^{95}$ or the Boțād and Sāyalā traditions (6 sādhus each), were and often are homogeneous male groups. ${ }^{96}$

The principal factor for the emergence of exclusively male groups is schisms. Generally, divisions are only instigated by $s \bar{a} d h u$ s who initially form small single sex groups which, after a while, may or may not accrete an entourage of $s \bar{a} d h v \bar{\imath}$. 
The severance of the Terā Panth from the Ragunātha Sampradāya in 1760 is one example. In some cases breakaway groups are formed by both sādhus and $s \bar{a} d h v \bar{\imath}$ s. But even then, $s \bar{a} d h u$ s are generally the majority.

Larger groups of up to 100 mendicants seem to have emerged more frequently at the end of the nineteenth century with the general revival of Jainism. In response, some groups, such as the influential Amarasinha Lavjīrși tradition, re-introduced rudimentary hierocratic structures to prevent the breakup of their communities. Organisation is necessary for the integration of nuns and for the reproduction of a monastic order over time. The need for organisation arises in times of expansion, when the mendicant orders grow and attempt to exert their influence on society as a whole. Organisation is also a major factor determining group size, as indicated earlier. It is symptomatic for an increase in power, not necessarily purity, because it counteracts the segmentary pressures that are systematically generated by the observation of the canonical rules for mendicant-lay interaction. These rules prescribe the itinerary of the ascetics and unmediated faceto-face interaction between guru and disciple, thus impeding the permanent aggregation of large assemblies of ascetics in small towns and villages. Even sizable and well-organised groups are split into smaller itinerant groups of 2-15 and, rarely, up to 70 mendicants, called sanghā the observation of the canonical rules of non-violent conduct easier.

Another approach to the processes of group segmentation amongst Jain mendicants follows from network theory. I have outlined this approach in an earlier, yet to be published, paper (Flügel 1991) and restrict myself here to general remarks. As mentioned earlier, the size of sustainable groups depends partly on the number of followers in a given region. Studies in network size have shown that informal personal networks rarely exceed thirty individuals in a modern urban environment: 'In general it appears that there is probably a limit to the number of people with whom an individual might be in direct and regular contact, but as yet there does not seem to be enough empirical evidence available to provide an estimate of what it might be' (Mitchell 1969: 19f.). ${ }^{97}$

By observing the canonical codes of conduct for their itinerary, or vihāra, and the collection of alms, or gocarī, Jain mendicants are both forced and able to sustain much larger networks of personal, if formal, contacts. In practice, this often requires the keeping of lists of addresses and various other organisational techniques which cannot be detailed here. ${ }^{98}$ In other words, while the monastic code of conduct limits the size of mendicant groups, it simultaneously contributes to the widening of the circle of lay contacts. However, even if one accepts that the formalisation of mendicant-lay interactions through the Jain monastic code results in a larger personal network, there seems to be an upper limit of sustainable contacts (a figure which awaits to be calculated). Beyond this limit, both the mendicant order and the mendicant-lay network can only be enlarged with the help of hierocratic organisation. The permutations of this general postulate still await thorough sociological analysis. ${ }^{99}$ However, given that schisms privilege male ascetics, it seems that the sustenance of large numbers of female mendicants is 
predicated on the existence of large and formally organised monastic groups with the capacity of weaving partial individual or parivāra networks into aggregate group networks. Historically, the emergence of organised monastic orders amongst the Śvetāmbaras seems to be related to the problem of integrating the principally bilateral structure of descent of nuns and the unilateral structure of descent of monks within a single tradition. ${ }^{100}$

\section{Śvetāmbara Terā Panth}

Systematic research in the history of the Terā Panth began in 1946 under the supervision of Ācārya Tulsī, who commissioned Muni Navratnamal (1921-2004) to collect the biographies of all Terā Panth mendicants and asked his lay followers to submit all family records and personal notes on the movements of the mendicants, since little reliable data can be found in the writings of the early Terā Panth monks. It is due to Muni Navratnamal's meticulous study of these sources, spanning more than five decades, that the Terā Panth offers now almost complete published demographic data on the monastic order and on the individual life-histories of its ascetics from its inception in 1760. During the last four decades an annual census was conducted and published under the title Terāpanth Digdarśan. The demographic statistics extracted from these materials differentiate between region of origin (deś), caste (jāti), age (vay), marital status before initiation: unmarried (avivāhit), married (patnī/patī ko chorkar), or widowed (patnī/patī-viyog ke bād), age at the time of initiation (navalīg/bālig), initiation with or without spouse (sapatnī/patī sahit), initiation of one spouse after the other ( $p r a \bar{g}$ dīkșit patnī/patī), death (svargavās), departure (gan bāhar), and the name of the initiating ācārya. Most of the available data was compiled by Muni Navratnamal (1981 ff.) and published in 26 volumes under the title Śāsana Samudra. Slightly different figures are quoted by Muni Budhmal (1995) and in other Terā Panth publications. The statistics of different Terā Panth publications do not always match, but are reliable enough to support general conclusions.

The Terā Panth is governed autocratically by a single ācārya who is invested with the constitutional power to select his successor, to initiate all mendicants, to annually rotate the personnel of the itinerant groups, and to determine the number and size of the groups. This administrative technique is unique amongst Jain orders, although the ācārya of the Sthānakavāsī Jñāna Gaccha - always the monk with the highest monastic age - also rotates the personnel of the itinerant groups, while most other Sthānakavāsī orders similarly operate with only one ācārya. It was devised deliberately to counteract segmentary pressures resulting from the fact that traditionally the members of a sanghä $\bar{a}$ stayed together for life and automatically developed a distinct group identity and clientele. The centralised system of administration was introduced by Ācārya Bhikṣu (1726-1803) and refined by Ācārya Jītmal (1803-1881). It allowed the Terā Panth to grow both numerically and geographically well beyond the size of an average samudāya in the twentieth century. In 1955 the Terā Panth comprised of 


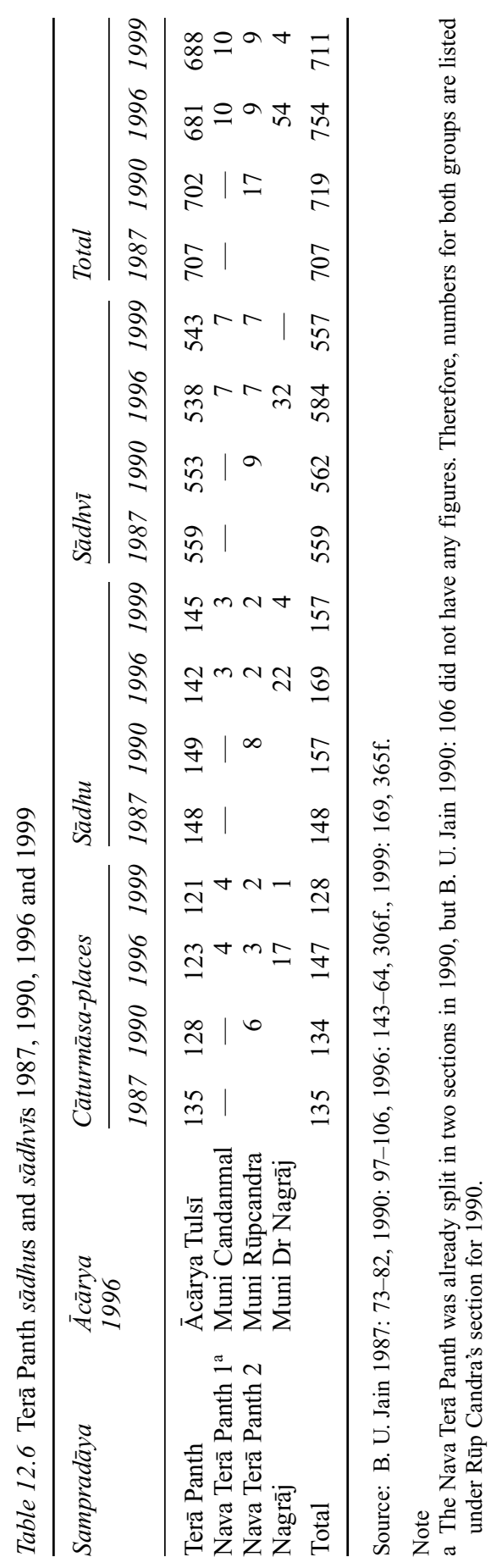




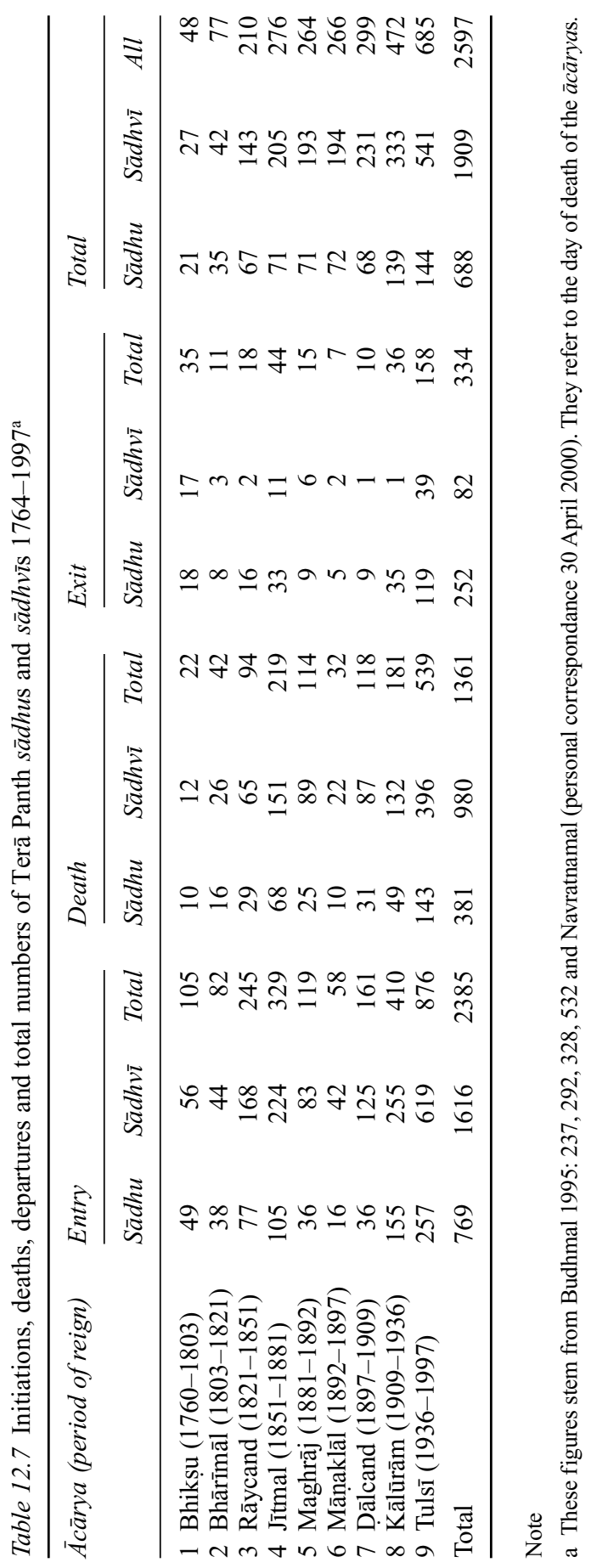


altogether 660 mendicants (180sādhus and $480 s \bar{a} d h v \bar{\imath}$ ), in 1975 of 657 mendicants (151 sādhus and $506 s \bar{a} d h v \bar{\imath} \mathrm{s})$ and in 1981 of 695 mendicants (164sādhus and $531 s \bar{a} d h v \bar{\imath} \mathrm{s}) .{ }^{101}$

The 1981 figures would have been higher had they not been compiled shortly after the secession of the groups of the Muni Nag Rāj and the Nava Terā Panth, lead by Muni Candan Māl and Muni Rup Candra. The main reason for the constitution of breakaway groups was the controversial introduction of a new intermediary category of novices, called samaṇa śreṇī, by Ācārry Tulsī in 1981. The dispute leading to the division focused on the decision to allow these novices to travel abroad and to use modern means of transportation and even money. In this respect, Terā Panth samaṇas resemble the bhattāakak of the Digambara and the yatis of the Śvetāmbara, which form similar categories midway between the laity and fully initiated mendicants. ${ }^{102}$ While orthodox ascetics rejected the innovation, reformist ascetics were disappointed that the reforms did not go far enough.

Initially, the samana śreñ $\bar{l}$ proved to be extremely popular, at least among young females, who were interested in religious education and travel. But the expansion has periodically slowed down. In 1992 the order comprised of 4 samanas and 51 saman̄īs, in 1996 of 4 samanas and 81 samaṇiss, and in 1999 of 4 samaṇas and 80 saman̄is. ${ }^{103}$ However, in the meantime the recruitment has been accelerated. Altogether 89 samanīs existed by 2001, and more than 100 in 2003. The periodical reduction in numbers is a result of the progression of many saman̄is into the order of the $s \bar{a} d h v \bar{\imath} \mathrm{s}$.

In 1992 the main branch of the Terā Panth had altogether 827 ascetics and novices and apparently more than 300,000 lay followers. At that time, it was one of the largest corporate Jain mendicant groups. If ascetics and novices are taken together, the Terā Panth had also the highest rate of growth of all Śvetāmbara Jain orders between 1987-1999. However, if only the numbers of fully initiated ascetics are taken into account, the growth rate seems to be stagnating. Table 12.6 shows that the main group had 688 members in 1999, $145 s \bar{a} d h u$ s and $543 s \bar{a} d h v \bar{\imath}$, that is, much more than in 1955, particularly if the 23 ascetics of the splinter groups of Muni Dr Nag Rāj and the Nava Terā Panth are taken into account. But the figures confirm the stagnation of the number of fully initiated ascetics between 1987 and 1999. This general trend is underlined by the low recruitment of male novices (samana), whose growth has stagnated.

The main expansion of the Terā Panth occurred under Ācārya Kālū Rām (1877-1936) and Ācārya Tulsī (1914-1997) in the first half of the twentieth century, that is, during the Indian struggle for independence and the first decade after independence. Table 12.7 shows that under Kālū Rām's reign both the absolute number of initiations of mendicants and the ratio of female mendicants increased dramatically. Simultaneously, caste exclusivity also increased. Terā Panth mendicants were increasingly recruited only from the Osvāl jātis. By contrast, many of the ascetics that were initiated by the first four Terā Panth ācāryas between 1760 and 1881 were Agravālas (sometimes Sarāvagīs) and Porvālas, and Maheśvarīs, though Bhikṣu himself was also a Bīsa Osvāl. ${ }^{104}$ The recruitment 
patterns also reflect regional changes. Initially, most of the Terā Panth mendicants came from Mārvāṛ and Mevār. However, after a series of cāturmāsa sojourns by Ācārya Jītmal in Lạ̄̂nūm and Bīdāsar between 1872 and 1877, the focus of activities shifted towards the Thalī region. From Ācārya Kālū Rām onwards the great majority of Terā Panth ascetics were recruited from the area of the old principality of Bīkāner. ${ }^{105}$ Table 12.7 shows the pattern of growth of the Terā Panth, whose àcäryas initiated altogether 2597 mendicants between 1760 and $1997 .{ }^{106}$

The table shows that one of the factors contributing to the low number of $s \bar{a} d h u$ s are secessions or excommunications, which occur much more frequently amongst $s \bar{a} d h u$ s than amongst $s \bar{a} d h v \bar{\imath}$ s (cf. Navratnamal 1981 II: 311, 322, III: 273, 291, X: 309, 325). This confirms Balbir's (1983: 42) observation that the disposition to rebel against the autocratic regime of the Terā Panth ācāryas is greater amongst male ascetics. The figures show that the number of exclusions was much higher under the regimes of the reformist disciplinarians Jitmal, Kālūrām and Tulsī.

Goonasekere's (1986: 87ff.) analysis of the recruitment patterns between 1760-1944 shows that, with the exception of the first years after the foundation of the Terā Panth during which the $s \bar{a} d h u$ s were in the majority, at all times significantly more $s \bar{a} d h v \bar{\imath}$ s were initiated than $s \bar{a} d h u$ s (on average $65.97 \% s \bar{a} d h v \bar{\imath}$ s and $34.03 \% s \bar{a} d h u s$ ), and that the percentage of female ascetics continually increased. His investigations of the marital status at the time of initiation give further insights into the historical changes taking place within the monastic community. He shows that until 1944 the two dominant categories were 'unmarried men' and 'widows': $49.83 \%$ of all sādhus were unmarried between $1760-1944,37.28 \%$ widowed, $12.89 \%$ married, and altogether $67.77 \%$ of the $s \bar{a} d h v \bar{v} \mathrm{~s}-44.77 \%$ of all Terā Panth mendicants - were widows (ibid.: 100f.). Goonasekere explains the different ratio of widows and widowers by the fact that, in contrast to women, men were always permitted to remarry (due to Ācārya Tulsī's reforms widow remarriage is today officially accepted by the Terā Panthīs though it is still despised by the Osvāls). From this he infers the prevailing motives for renunciation: widowhood for women, and impossibility or fear of marriage for men. But he also mentions other socially induced reasons for renunciation, such as infertility, bankruptcy, unhappy marriage, and death of a family member (ibid.: 114f.) - in my experience a very, if not the most, significant external factor, particularly for women, apart from the influence of the monks and nuns, and the alternative to marriage that is offered to women by a well-organised monastic order. ${ }^{107}$

Cort's (1991: 660) re-analysis of Goonasekere's data reveals important changes in the marital status of the Terā Panth ascetics. Under Ācārya Bhikṣu (1760-1803) less than $10 \%$ of all mendicants were unmarried. However, between 1909 and 1944 all mendicants under Âcārya Kālū Rām and Ācārya Tulsī were unmarried (women: $72.7 \%$, men: $56 \%$ ). Similar increases in the share of unmarried women amongst the $s \bar{a} d h v \bar{s}$ had already been observed by Shāntā (1985: 320, 336f., following Bordiyā 1975) for the Sthānakavāsīs and the Kharatara Gaccha, and by Cort (1989b) amongst the Tapā Gaccha samudāyas. Cort (1991: 660) 
rightly concludes that 'P. S. Jaini's (1979: 247, n. 8) statement that most Jain $s \bar{a} d h v \bar{\imath} \mathrm{s}$ are widows needs to be qualified'.

The average age at the time of the initiation has also increased. It is today 18-19 years, compared to 15-16 years some sixty years ago. The significant increase of the age of initiation can be explained by Ācārya Tulsī’s reversal of Ācārya Kālū Rām's preference for child initiations ( $b \bar{a} l a$ dì $k s ̣ \bar{a}$ ). Kālū Rām favoured child initiations in order to reduce the prevalence of widows in the order and to boost the overall number of mendicants. ${ }^{108}$ Tulsī, by contrast, was primarily interested in increasing the standard of education. The rising age of initiation is mainly a consequence of his decision to initiate only educated female candidates, given the overall trend towards the initiation of young unmarried women, who seem to prefer the relative independence of monastic life to marriage. One of the reasons for the creation of the samana category was to give young women the opportunity to study and thus to qualify themselves for full mendicancy, which nowadays can only be entered by young females after some years as a novice. Usually, girls are not initiated before the age of 20. But there is no such arrangement for boys, who are generally less inclined to join mendicancy. They are trained after initiation.

Initiations of children from the age of 8 and initiations of 45-60 year olds are exceptions today, although they still take place. ${ }^{109}$

\section{Digambara}

With the exception of very small traditions, such as the Tāraṇa Svāmī Panth, the Gumāna Panth and the Totā Panth, ${ }^{110}$ the overwhelming majority of the Digambaras follow either the Terah Panth, the 'path of thirteen', or the Bīsa Panth, the 'path of twenty' or both traditions in a non-discriminate manner. In contrast to the aniconic Śvetāmbara Terah Panth, the image-worshipping Digambara Terah Panth - both are also called Terā Panth - was originally not a tradition led by mendicants but a lay movement. It emerged in the sixteenth and seventeenth centuries in North India in protest against the lax and ostentatious conduct of contemporary orange-clad 'Bīsa Panthī' ascetics, the so-called bhattāakas, whose 'modern'111 monastic lineages evolved from those of the naked munis and increasingly replaced them from the thirteenth century onwards.

The precise significance of the distinction between Terah Panthīs and Bīsa Panthīs is not known anymore. Nor do we know much about the history and organisation of the contemporary Digambara ascetics. ${ }^{112}$ Most writers associate the beginning of the Terah Panth movement either with Pandit Todarmal (1719-1766), an influential Digambara layman of Jaypur, or with Banārsīdās (1586-1643), a merchant and cofounder (ādiguru) of the Adhyātma circle in Āgrā which drew on the mystical philosophy of Ācarrya Kunda Kunda to inspire its own version of a non-ascetic lay religiosity that is oriented towards self-realisation through the direct meditative experience of the soul. Yet, the fundamental ideas of both the Adhyātma circle and the Terah Panth movement clearly antedated both Banārsīdās and Toḍarmal. ${ }^{113}$ Lath (1981: xxxvi-vii), for instance, points to the influence of the revenue minister of 
King Akbar, Rājā Ṭodarmal (died 1589) in Vārānasī and to his younger associate Bāsū Sāh, who introduced Banārsīdās to Digambara mysticism. Cort (2002: 63f.) emphasised the fact that 'we cannot conclude that an interest in Digambar mysticism equates automatically with the Terah Panth emphasis on reforming the Digambar ritual culture' (p. 66). It appears rather that in the sixteenth and seventeenth centuries the trans-sectarian Adhyātma circle in Āgrā and the more ritualistically oriented and more radically anti-bhattärak Digambara Terah Panth movement around Jaypur constituted distinct though related lay movements, which became indistinguishable only with the waning of the influence of the Adhyātma movement in the eighteenth century and the institutional consolidation of the Terah Panth through the construction of numerous temples in North India.

According to M. U. K. Jain (1975: 137f.), the radical anti-bhattāraka movement was started either in $1528^{114}$ or in the early seventeenth century by Amar Cand, a resident of Sānganer near modern Jaypur. The movement first called itself Vidhi Mārga, though its opponents mocked it 'Terah Panth', the path of (only) thirteen. The second account is corroborated by Lath (1981: xxxix), who points to Amar Singh as the founder of the 'Terah Panth' movement in 1626. The most detailed investigation of the origin of the Terah Panth/Bīsa Panth distinction was undertaken by Nāthurām Premī $(1912,1957)$, one of the main sources for M. U. K. Jain and Lath, who identified the oldest confirmed record of the word Terah Panth and of the year 1626 as its date of origin in Pandit Bakhat Rām's eighteenth century work Buddhivilās v. $631 .{ }^{115} \mathrm{He}$ concluded, therefore, that the origin of the Terah Panth must be located in the early seventeenth century. In Premī's (1912/n.d.: 22f.) assessment, the passage refers to the ritualistic Terah Panth and not to the Adhyātma movement, as Cort (2002: 67) argues. ${ }^{116}$ Premī (1957) later recorded three versions of the origin of the Terah Panth in the literature of its opponents. ${ }^{117}$ All of these point to the pivotal role of the family of Amrā Bhaumsā Godīkā of Sānganer: One version can be found in Bakhat Rām's work Mithyātva Khaṇdan Nātak of 1764, which describes how Amrā Bhaumsā Godīkā was expelled from the congregation of the brahmacāri Amar Cand [sic!] because of his ostentatious display of wealth. In turn, he founded his own group which initially had only thirteen (terah) members and was therefore mocked as the 'Terah Panth'. The group built a temple apparently with the help of a minister of the king of Amer. A second version is given in a poem called Kavitt Terāpanthkau by Cand Kavi. The poem describes how Jodhrāj Godīkā, the son of Amrā Bhaumsā Godīkā, in 1618 - a date which Premī regards as fifty years too early ${ }^{118}$ - repeatedly interrupted the sermon of the visiting bhațāraka Narendrakīti of the Balātkāra Gaṇa Dillī-Jaypur Śākhā of Amer. He was then expelled and founded his own group on the basis of thirteen unreported principles. The third and oldest version goes back to Jodhrāj Godīkā himself who, in his 1667/1669 Hindī translation of Kunda Kunda's Pravacanasāra, exploited the homonym of terah and terā by interpreting terah panth, 'path of thirteen', as terā panth, 'your path', that is, as another term for the 'Jina's path' or the 'right path'. ${ }^{119}$ Hence, the Śvetāmbara Terā Panthī ascetics must have borrowed their own identical explanation of the 
three possible meanings of their name from existing Digambara Terā Panth sources, ${ }^{120}$ though M. U. K. Jain (1975: 138) reports that N. Premī elsewhere expressed the view that the name tera panth only became current amongst the Digambaras after the founding of the Śvetāmbara 'Terā Panth' in 1760 - a view which may merely reflect the fact that Bakhat Rām's works Mithyātva Khaṇdan Nātak and Buddhivilās were composed in the year 1764 and 1770.

None of the sources cited by Premī give a clear answer to the question of the significance of the numbers thirteen and twenty in terah panth and bisa panth, which may indeed just reflect a superficial claim of superiority by the self-declared 'Bīsa Panthīs' 'since the number 20 exceeds 13 by 7' (Nathmal 1968: 7). The influential twentieth century Terā Panth pandịt Phūlcand Śāstrī (1985b: 538), a born Parvār, could therefore take the liberty to identify the Terā Panth with the 'orthodox Mūla Sangha of Kunda Kunda' and the Bīsa Panth with the 'heterodox Kāṣthā Sangha', ${ }^{121}$ and also to associate the 'pure line' (śuddhāmnāya) of the Parvār caste with the tradition of Kunda Kunda (ibid.: 536). ${ }^{122}$ Sāstrī could, of course, only identify the entire bhatțāraka tradition with the Kāṣthā Sangha by disregarding the known history of the muni and bhatțāraka traditions. However, many Terā Panthīs nowadays claim descent from the 'orthodox' Mūla Sangha and interpret the words terā panth as a designation of the 'right path' shown by the Jinas and Kunda Kunda. ${ }^{123}$ The words bisa panth, 'path of twenty', is in turn polemically depicted as a corruption of visam panth, 'irregular-' or 'poisonous path' (Śāstrī 1985b: 538), ${ }^{124}$ or as a corruption of viśva panth, 'universal path' (Glasenapp 1925: 357 for both versions).

\section{Digambara Terā Panth}

The Digambara Terā Panthīs are today guided by paṇdits, or lay intellectuals, who are associated with predominantly local religious trusts and temples. There is no unifying organisational framework. About 500-600 Terā Panth pandits exist in North India today with strongholds in Jaypur, Āgrā and Vārānasī. Most of them teach Jainism only part-time. Although they do respect 'true' Jain mendicants, ${ }^{125}$ the Terā Panthīs represent largely a temple-centred form of lay asceticism, whose main doctrinal inspirations derive more from the mystical writings of Ācārya Padmanandin, known as Kunda Kunda (Pkt. Koṇ̣a Kunda), than from Bhūtabāli and Puspadanta for instance. Their following has recently split between those who accept Kānjī Svāmī’s (1889-1980) deterministic interpretation of Kunda Kunda's teachings and those who do not. ${ }^{126}$

Two-thirds of today's Digambaras ${ }^{127}$ are said to be Terā Panthīs, ${ }^{128}$ who are the predominant Digambara tradition in Rājasthān, Madhya Pradeś and Uttar Pradeś, while the Bīsa Panthīs dominate in Mahārāstra, Karnātaka and Keralā, as well as in Tamil Nāḍu and Gujarāt where only few Digambaras are left ${ }^{129}$ apart from the followers of Kānjī Svāmī. The reasons for the differential distribution of Terā Panthīs and Bīsa Panthīs have not yet been studied, but there seems to be a clear correlation between caste membership and sectarian affiliation in North India, where, today, most Agravāls and Parvārs are Terā Panthīs and most Khaṇụelvāls 
Bīsa Panthīs. ${ }^{130}$ However, the majority of the Digambara laity does not consciously differentiate between Terā Panthīs and Bīsa Panthīs qua sectarian membership or following, and merely practises local Jain rituals and caste customs. ${ }^{131}$ The absence of deep-seated sectarian awareness amongst the Digambara laity in North India ${ }^{132}$ apart from the divide between the followers and the opponents of Kānjī Svāmīi ${ }^{133}$ can be attributed to a number of factors: the extinction of the last North Indian bhattāaraka seats in the early twentieth century, the revival of the doctrinally amorphous muni traditions, and the lack of organisation not only of the Terā Panth, ${ }^{134}$ but of the Digambaras in general whose dearth of inspirational religious leaders in the nineteenth century resulted in the dominance of caste $(j \bar{a} t i)$ identities amongst the local Digambara communities (samāj) in both North- and South India. ${ }^{135}$ Another factor may have been the long-standing cultural influence of Terā Panth practices on the Bīsa Panthīs in North India, whose rituals are less elaborate than those of the Bīsa Panthīs in the South. ${ }^{136}$

\section{Bìsa Panth}

In contrast to the Terā Panthīs, who practise a dry pūjā and reject the bhatțārakas, the Bīsa Panthīs practise $p \bar{u} j \bar{a}$ with flowers and fruits and support the bhatțārakas, who continued the ascetic tradition after the decline of the munis in the late medieval period. The reconstruction of the organisational history of the Digambara ascetics is a difficult and not yet fully accomplished task. ${ }^{137}$ Carrithers (1990: 154) suspects that the current use of specific designations for monastic lineages or groups is largely fictitious since from the medieval period onwards no independently organised muni sanghas existed besides the bhattärakas. One of the problems is the unclear contextual meaning of the lineage and group categories used by the Digambaras. Muni U. K. Jain (1975: 132) writes that 'Units like Āmnāya, Anvaya, Bali, Samudāya, Samgha and Vamśa appear to be peculiar to the Digambara section'; though he does not fail to mention the common use of the terms gana, gaccha, kula and śākha in both the Digambara and the Śvetāmbara traditions. ${ }^{138}$ The difficulty in connecting the influence of the classical Digambara teachings of Umāsvāmī, Guṇadhara, Puṣpadanta and Bhūtabalī, on the one hand, and the mystical tradition of Kunda Kunda, on the other, with specific lines of succession is, at least in part, connected to the problem of clearly identifying enduring organisational units within the relatively unorganised Digambara ascetic lineages. It has only sporadically been observed that the doctrine of Kunda Kunda, who in old inscriptions is generally associated with the Nandi Sangha, was more prominent in the Māthura Gaccha and in certain factions of the Sena Gana. ${ }^{139}$

The nineteenth century pattāovalīs of the Sarasvatī Gaccha (Balātkāra Gaṇa Uttara Śākhā), which were translated by Hoernle $(1891,1892)$, trace the origin of the lineages of the contemporary Digambara bhatțārakas to a disciple of Ācārya Bhadrabāhu II, Guptigupta, who is also known under the names of Ardhabalin and Viśākhācārya. ${ }^{140}$ Ardhabalin is presented as the last pontiff who was able to keep the 
monks (muni) of the originally undivided Mūla Sangha, or root community, together. When he was succeeded, apparently in the year 21 BCE, each of his four chief disciples - Māghanandin, Vrșabha called Jinasena, Sinha and Deva - took over one of the four sub-groups which subsequently developed into independent traditions: the Nandi, the Vrssabha- (Sena-), the Sinha- and the Deva Sangha. ${ }^{141}$ The oldest sources for this narrative are two inscriptions in Śravanabelagolā dated 1398 and 1432. ${ }^{142}$ The later inscription dates the group formation within the Mūla Sangha to the latter half of the eight century. ${ }^{143}$ Schubring (2000: $\S 30$, p. 63) pointed out the discrepancy between this account and references to a Mūla Sangha of a different internal composition of the twelfth to thirteenth centuries, and Dundas (2002: 122) concludes 'that the Mūla Sangha gradually became little more than a prestigious but artificial designation, redolent of a long unattainable orthodoxy'. ${ }^{144}$

For the early medieval periods four 'heterodox' Digambara traditions are attested to by Deva Sena's tenth century polemical work Damsanasāra (Darśanasāra): ${ }^{145}$ the Drāviḍa-, Kāṣthā-, Māthura- and the Yāpanīya- or Gopya Sangha. The four traditions are described as 'heterodox', because they differed on specific points of doctrine and practice from the 'orthodox' Mūla Sangha, ${ }^{146}$ which is not mentioned in the text because it was represented by Deva Sena himself (Schubring 2000: $\S 30$, p. 63). ${ }^{147}$ The reported dates of origin of these traditions vary in the surviving manuscripts of the Darśanasāra. Hence, the Drāvida Sangha may have been founded either in $479 \mathrm{CE},{ }^{148} 469 \mathrm{CE},{ }^{149}$ or in $583 \mathrm{CE}^{150}$ by Pūjya Pāda's disciple Vajra Nandin in Madurā (Madurai) in South India. The reported reason was a disagreement within the Mūla Sangha over the eating of particular plants, bathing in cold water, practising agriculture and trade. ${ }^{151}$ The origins of the Kāsthā Sangha ${ }^{152}$ seem to go back to the seventh or eighth century CE. By the tenth century it was divided into four divisions: ${ }^{153}$ the Măthura Gaccha, ${ }^{154}$ Lāḍa Bāgaḍa/Lāṭa Vargaṭa Gaccha, ${ }^{155}$ Bāgaḍa Gaccha ${ }^{156}$ and Nandī Taṭa Gaccha. ${ }^{157}$ The Yàpaniya Sangha - the only one of the four 'heterodox' traditions which is depicted as a non-Digambara tradition in the academic literature ${ }^{158}$ originated apparently in $648 \mathrm{CE},{ }^{159}$ in $159 \mathrm{CE},{ }^{160}$ or in $148 \mathrm{CE} .{ }^{161}$

In North India the most influential traditions ${ }^{162}$ were the Sena Gana ${ }^{163}$ and the Balātkāra Gaṇa (Sarasvatī Gaccha) ${ }^{164}$ with its ten sub-divisions which were internally further sub-divided: Kārañjā Śākhā, ${ }^{165}$ Lātūra Śākhā, ${ }^{166}$ Uttara Śākhā, ${ }^{167}$ Ị̇ara Śākhā, ${ }^{168}$ Bhānapura Śākhā, ${ }^{169}$ Surat Śākhāa, ${ }^{170}$ Jerahaṭa Sākhā, ${ }^{171}$ Dillī-Jaypur Śākhā, ${ }^{172}$ Nāgaura Śākhā, ${ }^{173}$ and Atera Śākhā. ${ }^{174}$ Both the Sena Gaṇa and the Balātkāra Gaṇa presented themselves as branches of the 'orthodox' Mūla Sanigha in a direct line from Kunda Kunda (Padmanandin). However, the link appears to be a later construction. ${ }^{175}$ The currently available sources point to Ācārya Śrī Candra (r. 1013-1030) as the founder of the Balātkāra Gana. ${ }^{176}$

After the demise of the Yāpanīya- and the Drāviḍa Sangha in the late medieval period, merely a few branches of the Kāsțhā Sangha - especially the Māthura Gaccha - and of the Sena Gaṇa, the Balātkāra Gaṇa and the Deśiya Gaṇa of the Mūla Sangha remained, and only some sections of the Sena Gana and the Balātkāra Gana survived until today. In the late medieval period the members of 
most sub-branches of these traditions transformed themselves from naked munis to orange-clad bhattārakas with a relaxed code of conduct. These domesticated bhattāarakas had only very few disciples, amongst them occasionally nuns $(\bar{a} r y \bar{a}),{ }^{177}$ which may be the reason why the term yati is rarely used in the Digambara tradition. There is no reliable demographic information available on the bhattāaraka traditions, but one can safely assume that the absolute number of both Digambara munis and yatis was very small during this period. In the first of his planned two volumes on the early bhatțāraka traditions, Joharāpurkara (1958: 23) identified the names of only 400 bhatțārakas and 165 disciples who were associated with 31 jātis and 200 place names in North India between the thirteenth and nineteenth centuries.

\section{Bhatțāraka traditions}

The honorific title bhattāaraka, 'great lord' or 'learned man', was given to prominent $\bar{a} c \bar{a} r y a$ s and munis in the early medieval period (Premī 1912/n.d.: 3ff.). From the late medieval period onwards, the term came to designate the celibate heads of monasteries (matha $)^{178}$ who observe a relaxed set of ascetic vows, which entitles them to wear clothes, to administer monastic property in the name of the sarigha (private property is not permitted), to live permanently in one or more monastery, to use vehicles, to act as heads of the Jain communities and later of Jain castes, etc. To distinguish the two types of bhatțārakas, the term pațācārya is also used for the latter. ${ }^{179}$ Domesticated bhattārakas are not fully initiated mendicants, but occupy an intermediary status between the naked munis and the common laity. ${ }^{180}$ Technically, they are defined as ksullakas and classified together with the ordinary kșullakas and ailakas as 'superior laymen' (utkrșta śrāvaka) who accept to observe the eleventh śrâvaka pratimā, to different degrees, in contrast to the 'basic' (jaghanya) and the 'intermediate' (madhyam) laity, who must only observe the pratimās 1-6 and 1-9 respectively. ${ }^{181}$ In practice, jaghanya śrāvakas observe at best the first or darśana pratima , that is the stage of 'right views' combined with vegetarianism. The barah vratas or 'twelve vows' of the second or vrata pratima are rarely formally accepted (in toto) by lay Jains, who are reluctant to impose lifelong (ajjīvana) vows upon themselves, except sometimes in old age. ${ }^{182}$ Similarly, the intermediate status is regarded as almost synonymous with the seventh or brahmacarya pratima $\bar{a}$, the vow of sexual continence which is outwardly marked by wearing a white dress. The eleventh or uddista tyāga pratima $\bar{a}$, which should be practiced by bhattārakas, demands world-renunciation and the observance of a monastic lifestyle, including the begging of food. The uddista tyāga pratima is today sub-divided in the stages of the kṣullaka and the ailaka. ${ }^{183}$ The kșullaka (f. kṣullikā) or 'junior' (monk) gives up all but two (or three) pieces of cloth of orange colour, while the ailaka keeps only a loincloth (kaupina). ${ }^{184}$ Both the kșullakas and ailakas are consecrated by a personal guru. At their $d \bar{\imath} k s \underline{a}$ they are both given the three possessions of a Digambara ascetic: peacock feather broom (piñchī), scripture (śāstra) and water pot (kamandalu). ${ }^{185}$ In contrast to the kṣullakas, who may reside with householders, the ailakas always stay with the munis, and should eat their food, like 
the munis, with 'one hand', that is the two hands folded into one, but in a seated position. They also have to practice keśa luñcana, or the ritual plucking of hair and beard, and silence at night, and are not permitted to use vehicles. ${ }^{186}$ For this reason ailakas are considered to be superior to bhattârakas although this is disputed some bhattāakas who as the descendants of the original muni tradition claim predominance even over the modern munis and perform a modified muni dikșā.

The procedures of selection and the inauguration or pattābhiseka ceremony of a bhațāaraka are different from an ordinary kṣullaka dīkșa which usually precedes it. Nowadays, a bhatțāraka is often not chosen by his predecessor, but by a pañcāyat or by prominent members of the community, who judge the available candidates according to their attitude, conduct and knowledge. If no suitable successor, a laghunandana or 'small son' such as a brahmacārī or yati under training ${ }^{187}$ with a good horoscope, is available, the àcäryas of the muni sanghas are approached to recommend one of their kșullakas or ailakas who could be persuaded to fill the position. ${ }^{188}$ If a candidate is accepted by consensus, the pattāahiseka is organised, in which a Digambara muni plays the role of the $d \bar{\imath} k s \bar{a}-d \bar{a} t \bar{a}$ or giver of initiation. The candidate first renounces his old clothes and his personal name ${ }^{189}$ in public and is then given a single orange dress and the traditional title of the occupier of the seat. After taking his vows (at least a lifelong brahmacārya vrata), he is blessed with mantras and by sprinkled water on his head and then presented with the principal insignia of a bhațtâraka - a piñchī with a handle made out of silver or gold, an insignia ring, and a metal kamandalu. A bhattāraka also commands ceremonial elephants, litters (meña), and other symbols of worldly status. Generally, he does not keep money on his own nowadays, but leaves the financial assets of the matha in the hands of the lay trustees, who will cover all his expenses. ${ }^{190}$

The tradition of domesticated bhattārakas evolved at the beginning of the thirteenth century under Muslim rule from the existing traditions of the naked munis who they replaced almost entirely until the revival of the muni tradition in the twentieth century. There are three accounts of its origin, all of which emphasise the pioneering role of the Balātkāra Gaṇa: The first account attributes the introduction of the custom of wearing clothes - symbolic of possessions in general - to Ācārya Vasant Kīrti (1174-1207) of the Uttara Śākhā of the Balātkāra Gaṇa, who died only one year after his accession to the seat in Ajmer. According to Śruta Sāgar Sūri, he took the decision to cover himself with a sheet of cotton (tattî-sādara) when going for alms in the village of Maṇ̣apadurga (Māṇạalagaṛh) in Rājasthān in reaction to the Muslim rulers' criticism of the custom of walking naked in public. ${ }^{191}$ Other accounts locate the beginning of the practice in the time of Phīroz Sāh (1350-1387), the sultan of Delhi, who desired to meet the guru of the Digambaras. ${ }^{192}$ A pattā vali names the seventh $\bar{a} c \bar{a} r y a$ of the Uttara Sākhā of the Balātkāra Gana, the miracle working Padma Nandin (born 1318, r. 1328-1393), ${ }^{193}$ as the first bhattāraka who put on a loin cloth. It is said that the title of a bhattāraka was conferred on him by a Gujarātī śrāvaka who wanted him to consecrate a statue and in this way to transmit to it his miraculous powers (Hoernle 1891: 354). According to an oral tradition, the reason for putting on clothes was Padma Nandin's acceptance of the request by 
King Muhammad Ghôrî to present himself in a decent manner to his wife who desired to meet him (ibid.: 361). ${ }^{194}$

Under the impact of the Terā Panth reform movement in the sixteenth and seventeenth centuries, most of the bhattāraka seats in North India collapsed. The two last remaining seats in Rājasthān, Mahāvīrjī and Prātapgaṛh, were discontinued in the first and second half of the twentieth century respectively, due to the increasing influence of the 'modern' lay reform movements which criticised the bhattāakak with arguments similar to those of the 'protestant' 195 Digambara reform movements of the sixteenth and seventeenth centuries. ${ }^{196}$ Only the southern bhaț̣āraka traditions of the 'Mūla Sangha' in Mahārāștra (Sena Gaṇa: Kolhāpura, Nāndan̄ī), Karṇātaka (Balātkāra Gaṇa: Hūmachā; Deśiya Gaṇa: Kambadahalli/ Nagamañgala, Kanakagiri/Maleyur, Kārkala, Mūḍabidrī, Śravaṇabeḷagoḷā; Sena Gaṇa: Narasinhharājapura) and Tamil Nāḍu (Sena Gaṇa: Melasittamūra (Arahatasugiri); Deśiya Gana: Tiruvannamalai) survived. The institutional pillars of the present-day Bīsa Panth traditions, the twelve ${ }^{197}$ surviving bhattāaraka seats in Hūmachā, ${ }^{198}$ Kambadahalli, Kanakagiri, Kārkala ${ }^{199}$ Kolhāpura, ${ }^{200}$ Melasittamūra, ${ }^{201}$ Mūḍabidrīi, ${ }^{202}$ Nāndaṇ̄ ${ }^{203}$ Narasinhharājapura, ${ }^{204}$ Śravanabeḷagoḷā, ${ }^{205}$ Sondā/Svādī and Tiruvannamalai are all located in the south, and closely connected with individual local castes. ${ }^{206}$ The cultivation of exclusive links with the members of specific Jain castes in South India was facilitated by the fact that many of them were founded by bhattārakas, ${ }^{207}$ who protected and dominated them for centuries as their religious rulers, or rājāgurus, who exercised penitential powers. The bhatțārakas still initiate and excommunicate their followers and in some cases select their own successor, who is then installed by the members of the respective caste and cannot be removed during his lifetime. ${ }^{208}$ In the past, the bhattārakas accumulated large assets in land and artwork and maintained an exclusive monopoly over the surviving manuscripts of the principal sacred scriptures of the Digambaras, the Kașāyapāhuḍa of Guṇadharācārya and the Șațhaṇ̣āgama of Puṣpadanta and Bhūtabalī, until copies were produced and smuggled out of the mața of Mūdabidrī in the early twentieth century.

The exclusivist orientation of the bhättārakas towards the castes which they dominated and to the property of their sarigha proved to be a major obstacle to the ambitions of Jain communalists to unify the Jain community on a national platform during the years of the freedom struggle in the nineteenth and twentieth centuries. Sangha reforms were imposed on the bhattârakas by the laity, who also increasingly took control of the monastic property from the latter half of the nineteenth century onwards. Much of the landed property was recovered by the state governments through Land Reform Acts. ${ }^{209}$ As a consequence, the legal powers which the bhattärakas once held over their followers have now completely disappeared. With the re-establishment of separately organised sanghas of itinerant naked munis in the $1920 \mathrm{~s},{ }^{210}$ who were predominantly recruited from the relatively impoverished agricultural Digambara castes of the Bogāras, Caturthas, Pañcamas and Saitavālas in northern Karṇạtaka and southern Mahārāșța, even the southern bhattārakas lost much of their worldly and religious influence. They 
have no disciples amongst the newly established lineages of munis and āryikās, who are independent and considered to be of a higher religious status. ${ }^{211}$ However, they are still consulted as arbiters for conflict resolution, and supervise the conduct of the upādhyāyas who conduct the temple rituals in southern India. It is due to the continuing influence of the bhattārakas on the social life of South Indian Jains that their castes tend to be homogenously 'Jain' and that the feeling of 'Jain' social identity, is more prevalent than in mixed Jain-Hindu castes.

The lack of credible mendicant leaders with a national reputation may explain why the desire for social and religious reform was at the time particularly strongly expressed by the Digambara laity in North India. Another factor was the aspiration of some community leaders to bridge the caste divisions, and the economic divide between the poor Digambara agriculturists in the South and the wealthy Digambara (and Śvetāmbara) merchants in the North. The revival of the munis came therefore just in time. The munis were promoted by the laity as symbols of Digambara unity on a national platform. ${ }^{212}$ Particularly the leading members of the Akhil Bhāratvarșīya Digambara Jain Mahāsabhā and the Khaṇ̣elvāla Mahāsabhā ${ }^{213}$ associated themselves closely with the new muni sangha. ${ }^{214}$ The reformist Akhil Bhāratvarșiya Digambara Jain Parișad also supported the revival of the munis and the unity of all Digambaras, but advocated for social reforms in addition to the religious reforms which were promoted by the munis. ${ }^{215}$ The association was founded on the 22 January 1923 in Delhi by Champat Rāy Jain (1867-1942), Brahmacārī Sìtal Prasād Jain (1879-1942) and other reformers from North India who had left the conservative Bhāratvarșiya Digambara Jain Mahāsabhā, which was established in 1892 in Mathurā under Rājā Lakșmaṇdās and supported by traditional bhatțārakas and pandits, who resisted both the publication of the scriptures, ${ }^{216}$ and socioreligious reform movements amongst the Digambaras, such as the Dasa Pūjādhikāra Āndolan, the Dasa's Right to Worship Movement. ${ }^{217}$ Reportedly, some members of the Mahāsabhā even opposed the independence of the munis from the bhattāarakas. ${ }^{218}$

\section{History of the modern muni sangha}

The Digambara muni tradition never entirely disappeared, though for the nineteenth century the names of only a handful of munis are reported whose precise relationship, if any, with the bhatțärakas is still not entirely clear. ${ }^{219}$ A Muni Nara Sinha is reported to have visited the town of Dhākā with his disciple Muni Vinay Sāgar in 1870 , and another muni is reported to have visited Jaypur. ${ }^{220}$ In South India, several munis lived away from larger settlements on hillsides and in caves, though reliable information on them is difficult to obtain. Amongst them was 'Tapasvī' Muni Candra Kìrti, who was probably born in Guramandayā, but no detailed information on him is available. At the time, the only muni in North India was Candra Sāgar, who was born into the Padmasī family of the Hūmad caste in Phalațan (Satārā). He took the kṣullaka vow in 1912 in Jinappāsvāmī (Śolāpur) and a few months later the mahāvratas in Jhālarāpātan and started to wander as a naked muni as far as Āgrā. ${ }^{221}$ Muni Anant Kīrti was born in 1883 in Nellīkār (Kārakal) and died 
untimely on 16 February 1918 in Gvāliyar where, in his memory, an eternal light (akhanda jyoti) is still maintained by his followers. ${ }^{222}$ In South India, three additional munis existed: Candra Sāgar 'Manihalī', Sana Kumār, and Siddha Sāgar 'Tervāl' (1828-1903), ${ }^{223}$ who reportedly self-initiated himself in front of a statue at Sammet Śikhar. In 1921, one Muni Ānand Sāgar lived in Udaypur. It has been reported that he often visited the nearby shrine of Rșabhdeva Keśariyā. 224

Although the Digambara mendicants are not organised, most, but not all present-day munis trace their lines of descent to 'Cāritra Cakravartī' Śānti Sāgar 'Dakșin' (1872-1955) - not to be confused with his namesake from North India: Muni Śānti Sāgar 'Chāṇ̄̄' (1888-1944) - who is 'regarded as having revived the institution of munis single-handedly from nearly complete eclipse' (Carrithers 1989: 232). Sānti Sāgar was born on the 26 July 1872 (1929 Āṣạ̣̄h Kṛ̣ṇa 6) in the village Aināpur-Bhoj in the Belgāmv District of Karṇạtaka. His original name was Gauḍa Pātịl, and he belonged to a family of farmers of the Caturtha caste. When he was nine years old, he was married to a five year old bride, who died only seven months after the wedding. In 1890, he took the brahmacarya vow 'in the presence of a muni' ${ }^{225}$ on 25 June 1915 (1972 Jyesțh Śuklā 13), the kṣullaka vow from the Digambara 'muni' Devendra Kīrt,'226 in Uttaragrām, and in 1916 the ailaka vow from Muni Akalīk Svāmī (? = Ādi Sāgar 'Annkalīkar'), who lived on the Bāhubalī hill near Kumbhoj. He was finally initiated as a muni from another 'nirgrantha muni' on 4 March 1920 in Yarnāl (Yeranāl) in Karṇațaka ${ }^{227}$ and recognised as an ācārya after the initiation of his first disciple, Muni Vīr Sāgar, on 9 October 1924 (1981 Āśvin Śuklā 11) in Sānglī. He initiated altogether 18 munis, kșullakas, āryikās and kșullikās, most of whom accompanied him on his barefoot journeys throughout India.

At the time, roaming naked in the streets of large cities was prohibited (berok-tok) by the Colonial Government (K. P. Jain 1938: 161f.). In British India and in the Indian princely states (riyāsat) wandering naked was an arrestable offence. The munis were therefore more numerous in southern India. In 1926, the Commissioner of Kāthiyāvād gave permission for Muni Munīdra Sāgar to move lawfully, if he was surrounded by a circle of his devotees, though this restriction was opposed by the Akhil Bhāratīya Jaina Samāj, and a committee was formed to repell it with the argument that according to both British and a Indian law, neither the government nor any other ruler or sampradāya should interfere in the religious affairs of a particular tradition. ${ }^{228}$ When Ācārya Sānti Sāgar entered Bombay in 1927, the case was still pending. He therefore had to transgress the rule of wandering naked (nagna muni vihāra) and to cover his body during his visit to the city (Kāsalīvāl 1992: 35). On the request of the local Seth Ghāsīrām Pūnamcand Jauharī, he then lead a communal pilgrimage to the sacred sites of the Digambaras throughout India, to re-establish for the Digambara munis the right to roam naked and uninhibited by provincial boundaries, and to revive the 'true' Digambara religion. ${ }^{229}$ On his tour, he was welcomed by the provincial kings of Mahārāsțra. In the year 1927-1928, he led the pilgrimage from Bhopāl to the mahā sammelan of Digambara munis at Mount Sikhar in Bihārr, ${ }^{230}$ and on to Jabalpur, Lakhnaū, Kānpur, Jhāmsī̄, Āgrā, Dhaulapur, Mathurā, 
Phirozābād, Etạa, Hātharas, Alīgarh, Hāstīnapūr, Muzapharnagar, etc. to Delhi, where he spent cāturmāsa. He was famously stopped by the police in Delhi for breaking the law by walking naked, but was pardoned because he refused to move from the spot where he was stopped, asking: 'how can I walk back?' After cāturmāsa, he went on to Alavar for a sammelan of all existing sādhu ganas, that is, the groups of ascetics which performed mainly jñanna-dhyāna and tapas rather than the rituals promoted by the bhattārakas, though rituals were not rejected per se. The following six Digambara mendicant groups (sargha) were present (K. P. Jain 1932: 161f.):

1 Ācārya Śānti Sāgar 'Dakșin’, with the munis Candra Sāgar, Śrut Sāgar, Vīr Sāgar, Nami Sāgar and Jñān Sāgar (6 munis altogether).

2 Muni [Ācārya] Śanti Sāgar 'Chāṇī', with Muni Malli Sāgar, Brahmacārī Phatah Sāgar, and Brahmacārī Lakṣmī Cand (2 munis altogether). Sānti Sāgar 'Chān̄ì' was born as Kevaldās Jain into a family of the Dasa Humaḍ caste in the village Chān̄ī, some $15 \mathrm{~km}$ from Rṣabhdev Keśariyā in the state of Udaypur. He took the brahmacarya vrata on 1 January 1919 at Sammet Sikhara, and a few months later, with permission of the lay community of Gaṛhī in Rājasthān, initiated himself as kṣullaka under the name Śānti Sāgar in front of the image of 'Bhagavān Jinendradeva' (due to the absence of munis in North India). On 5 September 1922 (anant caturdāsís) in the Ādināth temple of Sāgavāra he started 'to wear the dress of a Digambara muni' (Digambara veșa dhārana). In 1926, he was installed as an ācārya by the Digambara community of Giriḍīha. He converted Țhākur Krūrasinhha of Bhukhiyā (Bāmsavārāā) to Jainism, but had fewer disciples than his counterpart in the south. ${ }^{231}$

3 Muni Sūrya Sāgar (9 November 1883 to 14 September 1952), with Ajit Sāgar, Dharma Sāgar and Brahmacārī Bhagavān Dās (3 munis altogether). Sūrya Sāgar's birthname was Hajārīmāl and he belonged to the Porvād caste of Jhālarāpāṭan. In 1916 his wife died. He was initiated by Śānti Sāgar 'Chāṇ̂̀' first as a ksullaka on the 19 October 1924 in Indore and a few weeks later as a muni on the 22 December 1924. In 1928 he was given the ācārya title from the $\operatorname{sama\overline {a}j.~He~initiated~at~least~four~male~ascetics:~Ācārya~Vijay~Sāgar,~Muni~}$ Ānand Sāgar, Muni Padma Sāgar, and Ksullaka Cidānand. ${ }^{232}$

4 'Muni'[Ācārya] Ādi Sāgar, (13 September 1866 to 21 October 1944) with Muni Malli Sāgar and Kṣullaka Sūri Sinhha. 'Mahātapasvī' Ādi Sāgar 'Añkalīkar'was born in the village Añkali in southern Mahārāștra. He belonged to the Caturtha caste and was named Śiv Gaurā by his parents. In 1909 he took the ksullaka vow, and in 1913 initiated himself in front of the Jinendra image at Kunthalgiri. He died in 1944 in the village Ūd (Kāsalīvāl 1992: 35, Suśîlā Bāī, in Brahmacāriṇī Mainābāi Jain 1996: iv-x). In the year 1926, his group stayed at Udgāmv (3 munis altogether).

5 Muni Munīdra Sāgar, with the munis Devendra Sāgar and Vijay Sāgar. Munīdra Sāgar was born in Lalitpur into the Parvār caste. He was very young in 1927 and spent his previous cāturmāsa in Māmdvī (Surat) (3 munis altogether).

6 Muni Pāy Sāgar, who restricted his movements to South India (1 muni). 
In addition, Muni Jñān Sāgar of Khairābād and Muni Ānand Sāgar (and possibly others for which no record is available at the moment) belonged to the Digambara sādhu gana. These 21 mendicants were the only naked munis who performed vihāra at the time.

It seems, though this is a question for further research, that of these six groups only the lineages of Śānti Sāgar 'Dakșin’', Śānti Sāgar 'Chāṇ̄', and of Muni Ādi Sāgar 'Ankkalīkar' survived. In accordance with the general tendency amongst modern Jains to present a homogenous image of the Jaina community to the outside world, it is often said that doctrinal disagreements are not significant within the tradition of the modern munis, only minor differences in lineage and succession. There is, indeed, no clear doctrinal division between the ācārya sanghas with regard to the Terā Panth/Bīsa Panth distinction concerning the latter's use of green vegetables, fruit, worship with lamps (dīpa pūja) or incense (dhupa), etc. Effectively, each ascetic follows his own interpretation. However, Ācārya Sānti Sāgar 'Chān̄ì' was known for his rejection of the pañca abhiseka ritual because it is conducted with milk. Instead he advocated for the use of 'pure' water in abhiṣeka rituals. He spent one cāturmāsa together with Śānti Sāgar 'Dakṣiṇ' in Byāvar, where differences of opinion emerged, since Śānti Sāgar 'Dakșin’’ insisted on the Bīsa Panthī view. Sānti Sāgar 'Chāṇ̂’s main line of succession is represented by the ācāryas Sūrya Sāgar (1883-1952), Vijay Sāgar, Vimal Sāgar (Bhinḍa) (1891-1973), Sumati Sāgar (1917-1994), and Upādhyāya Jñān Sāgar (b. 1957). ${ }^{233}$ However, a number of splits occurred due to succession disputes, and several guru-sísya paramparās exist today. ${ }^{234}$

Doctrinal disagreements were also instrumental for the schisms between the successors of Śānti Sāgar 'Dakșin', who after his death on the 20 August 1955 (2012 Bhādrapad Śuklā 2) in Kunthalgiri split into five independent lineages. Four lines were started by Śānti Sāgar's disciples Ācārya Nami Sāgar (1888-1956), Ācārya Pāy Sāgar (1890-1956), Ācārya Sudharma Sāgar (1885-1938) and Ācārya Kunthu Sāgar (1894-1945). However, the dominant line of his successors (pattadhāra or pattāâhiśa) is represented by the ācāryas Vīr Sāgar (born 7 June 1876, ksullaka 13 March 1924, muni 9 October 1924, ācārya 9 September 1955, died 23 September 1957), Śiv Sāgar (born 1901, dīkșā 7 July 1949, ācārya 3 November 1957, died 18 March 1969), Dharma Sāgar (born 11 January 1914, dīkṣa 13 December 1951, ācārya 24 June 1969, died 22 April 1987), ${ }^{235}$ Ajit Sāgar (died 1988), ${ }^{236}$ and the present ācārya Vardhamān Sāgar (dīkṣā 24 February 1969), who was chosen by Ajit Sāgar, though the older and much more popular monk Abhinandan Sāgar ( $d \bar{\imath} k s ̣ \bar{a} 29$ October 1968) was favoured by the majority of the lay followers. ${ }^{237}$ After Ajit Sāgar's death, Abhinandan Sāgar and his teacher Śreyāms Sāgar therefore separated themselves from Vardhamān Sāgar and founded their own group which is now headed by Ācārya Abhinandan Sāgar.

A third influential line was started by Ācārya Vīr Sāgar's disciple Muni Jñān Sāgar (c.1891-1 June 1973), a Khaṇụelvāla (Chābrāā) Jain from Sīkar, previously known as the Terā Panth Paṇdit Bhūrāmal Śāstrī and from 1955 as Kṣullaka Jñãnbhūṣaṇ (dīkṣa dātā: Ácārya Vīr Sāgar). He was intiated as a muni 
in 1959 in Jaypur by Ācārya Śiv Sāgar but seceded on doctrinal grounds from Śiv Sāgar and his dedicated successor Dharma Sāgar, in 1961 and - though not being recognised as an ācārya - initiated Vidyā Sāgar (dīksạa 30 June 1968) in the same Samvat year in Ajmer. In turn, he was installed as an ācārya by his disciple with the consent of his lay followers on the 7 February 1969 in Nasīrābād and immediately afterwards initiated Muni Vivek Sāgar (dīkșā 7 February 1969 or 8 March 1969). Vidyā Sāgar was born on the 10 October 1946 into a middle-class Aștage family of the Caturtha caste in the village Cikkoḍi-Sadlagā in Belgāmv. ${ }^{238}$ He took the brahmacarya vow from Ācārya Deś Bhūṣaṇ in 1967, and muni dīkṣa from Ācārya Jñān Sāgar, who appointed him as the new ācārya on the 22 November 1972 in Nasīrābād, and immediately afterwards resigned and asked Vidyā Sāgar to bestow upon him the sallekhanā vow (M. Jain 2001: 23-26, 494, K. R. Jain 2003: 23-52). After Jñān Sāgar's death in 1973, Vivek Sāgar parted company from Vidyā Sāgar, apparently because the charismatic Vidyā Sāgar was junior to him in physical age, although slightly older in monastic age. But the main reason may have been doctrinal differences. In the group of Vidyā Sāgar, $\bar{a} r y i k \bar{a}$ s cannot initiate ailakas, on behalf of the ācārya, on the grounds that the ailakas wear only one piece of cloth and therefore deserve a higher status than the āryikās, who cover their entire body. ${ }^{239}$ This reversal of the traditional hierarchy - muni, āryikā, ailaka, kṣullaka, kșullikā - was a main point of contention between Jñān Sāgar and Ācārya Śiv Sāgar. ${ }^{240}$ Other disputes concerned the consumption of 'green' vegetables such as tomatoes, and Jñān Sāgar's refusal to condemn the use of the sacred thread, which is common among the Digambara laity in South India but not practiced north of Karnātaka, which prevented him to become installed as an ācārya by Śiv Sāgar. Vidyā Sāgar additionally resolved that a ryikās should not wear the piñchī, the principal status symbol of a Digambara ascetic, during their menses, and that only 'born Jainas' should be able to become munis. The highest status for renouncers from non-Jain families amongst his followers is thus the position of an ailaka in his group. ${ }^{241}$

A fourth line was started by Ādi Sāgar 'Anikalīkar', who was a contemporary of Śānti Sāgar 'Dakșiṇ', and is often presented as his disciple, despite the fact that he was not initiated by him. ${ }^{242}$ He was succeeded by Mahāvīr Kīrti (born 1 June 1910, dīkṣā 1937, died 6 Febuary 1972) and Vimal Sāgar (born 30 October 1915, dīkșā 19 July 1950, ācārya 24 December 1961), who apparently gained the $\bar{a} c \bar{a} r y a$ title not through succession but by acclamation of the lay community, especially by the paṇdits Lālā Rām Śāstrī and Māṇik Candra Sāstrī. ${ }^{243}$ Both Mahāvīr Kīrti and Vimal Sāgar ${ }^{244}$ were succeeded by a great number of ācāryas who created numerous small groups. ${ }^{245}$ Vimal Sāgar's successors were Ācārya Sanmati Sāgar (born 26 January 1939, dīkșā 9 November 1962, ācārya 5 March 1972), and the current $\bar{a} c \bar{a} r y a$ s Bharat Sāgar (born 7 April 1949, dīkṣa 23 November 1972) ${ }^{246}$ (who was Vimal Sāgar's upādhyāya), ${ }^{247}$ Puṣpadanta Sāgar (born 1 January 1952, dīkṣa 31 January 1980) (who shifted from Vidyā Sāgar to Vimal Sāgar and teaches an idiosyncratic mixture of Terā Panth and Bīsa Panth views), Nirmal Sāgar (born 10 December 1946, dīkșā 12 July 1967), Sanmati Sāgar 
'Tapasvī Samrāt', Vāsu Pūjya Sāgar, Virāg Sāgar, as well as Muni Nirañjan Sāgar, Gaṇinī Vijay Matī, the kṣullakas Dhaval Sāgar, Ratna Kīrti, and the kșullikā Siddhānta Matī (A. Jain 2001: 1-34). Amongst Mahāvīr Kīrti's successors were the present ācārya Sambhav Sāgar and the present 'ganadharācārya' Kunthu Sāgar, who initiated many disciples under new names ending in the suffix -nandī. Some of his disciples parted from him in order to establish themselves as ācāryas, $\bar{a} c \bar{a} r y a k a l p a s$, upādhyāyas and munis in their own right - to name only the present ācāryas Deva Nandī, Guṇadhara Nandī, Guṇa Nandī, Gupti Nandī, Kanak Nandī, Karma Vijay Nandī (? = self-initiated), Karun̄ā Sāgar, and Kumud Nandī, Kuśāgra Nandī, Padma Nandī, Sānti Sāgar 'Korasār Vāle', the ācāryakalpas Karuṇa Nandī and Śruta Nandī, the ailācārya Niścay Sāgar, and the upādhyāyas Kāma Kumār Nandī Śruta Sāgar. Ācārya Deś Bhūṣaṇ (1908-1987), the politically most influential Digambara muni after Śānti Sāgar, was a disciple of Ācārya Jay Kīrti, who may have been associated with Mahāvīr Kīrti, though the link is not clear. ${ }^{248} \mathrm{He}$ is succeeded by the presently influential $\bar{a} c \bar{a} r y a$ Vidyānand 'Rāṣtrasant' (born 22 April 1925), who also comes from Belgāmv but has few disciples and resides predominantly in New Delhi, by Ācārya Bāhubalī Sāgar, who separed himself from Vidyānand and by Ācārya Subāhu Sāgar, Ācārya Subal Sāgar, Muni Gụ̣ Bhūṣaṇ, Kṣullaka Vṛ̣sabh Sena, and Kṣullikā Anant Matī (ibid.).

In 1981, 151 mendicants and representatives of the national Digambara lay associations gathered in Śravanabeḷagọā in order to witness the mahāmastakā $\bar{b}-$ hișeka ceremony and to overcome the differences between the growing number of Digambara ascetics and lineages by establishing a common institutional framework for the mendicants - the Digambara Jain Muni Parișad. Several rules were drafted with the intention of preventing the practice of wandering alone (ekala vihāra) and a decline in the standards of conduct (śithilācāra). But these resolutions were not implemented and had no effect (Kāsalīvāl 1992: 24).

Though there are no clear-cut divisions among the munis with regard to politicalideological and doctrinal orientations, conservative Bīsa Panthī munis tend to support the Mahāsabhā, while modern monks such as Ācārya Vidyānand and Ācārya Vidyā Sāgar associate themselves with the Mahāsamiti whose wealthy leadership has a wider support base in North India and tends to support Terā Panth views. The main catalyst for the recent trend towards a conscious doctrinal self-demarcation of Bīsa Panthī and Terā Panthī mendicant groups was the debate on Kānjī Svāmī’s idiosyncratic 'Terā Panth' interpretation of Kunda Kunda's philosophy from the early 1960s onwards, which split the Digambaras into two clearly distinguished factions. ${ }^{249}$ Beyond the specific context of this dispute, the picture is less clear. There is no exclusive link between Kunda Kunda and the Terā Panth tradition. In the late twentieth century, the Terā Panth pandit Phūlcand Sāstrī (1985b: 244, 1992: 146) came to the conclusion that the Terā Panth is identical with the śuddhāmnaya, the 'pure tradition' of the Mūla Sangha Kundakundāmnaya Balātkāra Gaña Sarasvatī Gaccha, ${ }^{250}$ which propagates the mokṣa mārga and not - like the Bīsa Panthī bhattāarakas ('= Kāṣthā Sangha') - the ways of living a religious life in the world (samsāra). The same claim had already been made at the beginning of the 
century by the Bīsa Panthī ācārya Sānti Sāgar 'Dakșiṇ' ${ }^{251}$ who, somewhat imaginatively, attributed himself to the line of the 'Mūla Sangha' Kundakundāmnaya Nandi Sangha Balātkāra Gaṇa Sarasvatī Gaccha (Jñān Matī 1980: 249) - which may have inspired Phūlcand Sāstrī’s view. Although few details about his life are known, Ācārya Kunda Kunda $(c .1-8 \mathrm{CCE})^{252}$ is currently regarded by all contemporary Digambara munis as their ancestor. ${ }^{253}$ According to Anupam Jain, ${ }^{254}$ all munis derive their descent from the lineage of Kunda Kunda and Ācārya Śānti Sāgar. ${ }^{255}$ However, although the majority belongs to the lineage of Sānti Sāgar 'Dakșin' and propagates southern, that is Bīsa Panthī, practices, a minority descends from Sānti Sāgar 'Chān̄ì', who rejected the Bīsa Panthī pañca abhiṣeka and devī pūjā rituals, and from Ādi Sāgar 'Añkalīkar'.

After the recent death of the influential Ācārya Vimal Sāgar (born 1915), the most prominent $\bar{a} c \bar{a} r y a$ s of today are Vidyānand (born 1925), who took the twelve year long sallekhanā vow in 1999, and the charismatic Vidyā Sāgar. Vidyā Sāgar is renowned and respected for his strict observance of the rules of the Digambara $\bar{A}$ gamas, and for his emphasis on Jain philosophy rather than on rituals and imposed vows; especially for his single-handed revival of the study of the Șaṭkhandāgama. He explicitly favours the Terā Panth view on rituals and speaks out both against the bhattārakas (first on 8 November 1998), ${ }^{256}$ and against the followers of the Kānjī Panth. Like his guru, Jñān Sāgar, who did not express any objections to the bhattāakas, he also favours the mystical teachings of Kunda Kunda. In contrast to his late rival, the ritualistically oriented Ācārya Vimal Sāgar, who was from a Khaṇdelvāl business class background and supported the Mahāsabhā, Vidyā Sāgar comes from a South Indian merchant family of modest income and favours the 'liberal' Digambara Mahāsamiti and the Digambara Parișad which promote both ritual and social reforms. ${ }^{257} \mathrm{He}$ explicity propagates the recognition of the Jains as a 'minority' community, which is now supported by most Digambaras, particularly in the South, where they form homogenous Jain castes. The North Indian Śvetāmbaras and Digambaras, especially those from Gujarāt and Rājāsthan, are traditionally selfemployed merchants and wealthier than the sourthern Digambara agriculturalists and petty traders whose preferred route of social advancement tends to be government service. They form predominately mixed Jain-Hindu castes and tend to oppose the minority status for Jains. ${ }^{258}$ Vidyā Sāgar is also a strong supporter of the cow protection movement and inspired the formation of a lay organisation called Ahimsā Army which is based in Delhi and works for a total ban on the slaughter of cows in India. ${ }^{259}$ It is possible that the North Indian cultural environment has influenced Vidyā Sāgar's change of attitude towards the bhaț̣arakas and the Bīsā Panthī tradition in general. He was born in Karnātaka, but recruited most of his disciples in the North, particularly in Madhya Pradeś, where he spends most of his time.

With the notable exception of the strictly anti-monastic Kānjī Panth, the revived muni traditions are today respected both by the Terā Panth panditit ${ }^{260}$ and by the Bīsa Panth bhattārakas, though the contact of the munis with either of them is irregular. ${ }^{261}$ In fact, the majority of the present-day mendicants attach themselves neither to the Bīsa Panth- nor the Terā Panth Digambara tradition, but act independently and are 
free to articulate their individual doctrinal interpretations. The widely held view that Digambara ascetics always preferred to impress people 'more by their behaviour than by their church organisation' and 'seemed to favour solitary life' (Deo 1956: 360f.) indirectly supports the claims of the modern munis that they are the revivers of the authentic form of Jain monasticism that was introduced by Mahāvīra himself. However, although the Digambaras did not, like the Śvetāmbaras, create elaborate monastic codes of conduct, their ācāryas and later their bhattārakas presided over mathas, or monasteries, which were highly organised manifestations of monastic landlordism. ${ }^{262}$ It was monastic property rather than a code of conduct which stabilised the tradition. The long-standing organisational and numerical weakness of the Digambara mendicants from the beginning of Muslim rule may thus be related to the relative success of the bhattāarakas as well as the educated laity, whose influence within the Digambara community is reflected in the extensive post-canonical Digambara Śrāvakācāra literature, which is partly written by lay intellectuals: 'Digambars seem to have felt more keenly than the Śvetāmbars the need to concretize and systematize the lay doctrine' (Williams 1983: xviii). The strength of the Digambara laity over the last 500 years also explains the leading role of Digambara intellectuals within the twentieth century Jain reform movement. Yet, the increasing influence of the scholars amongst the modern munis seems to displace the communal role of the lay intellectual for the time being.

\section{Organisation of the muni sangha}

Since the demise of the Drāvīẹa Sangha and other regional traditions, and with the ascendancy of the bhattāakas who profess to continue some of these traditions even today, Digambara mendicants are not split into distinct schools and sects anymore. Amongst modern munis the popular suffix -nandī or -sāgar does not indicate sectarian affiliation, only lineage affiliation. Not much is known about the doctrinal and organisational differences between the lineages. Maybe by using these suffixes some modern munis attempt to recapture the symbolic identities (and properties) of old bhattāraka lineages which are now extinct. But our empirical knowledge of Digambara history and sociology is presently not sufficient to answer this question. ${ }^{263}$ The lack of a reliable demographic survey of the contemporary Digambara ascetics was lamented by Carrithers (1989), who encountered great difficulties in his attempt to piece together a reasonably accurate ethnographic picture of the Digambara mendicants: 'The munis as I met them are significantly different from their predecessors, especially those in the nineteenth century. Munis are few. They have no central organisation and it is difficult to gather even the most elementary census data concerning them. Jaini (1979: 247, n. 8) estimated that there were only sixty-five munis when he was writing, and another sixty novices. An unattributable Hindi newspaper cutting shown to me by the muni Vidyānandajī Mahārāj in 1984 estimated the number of munis at 100. These numbers have to be understood in relation to the number of Digambar laity. The 1981 Census of India returned about three and a quarter million Jains of 
DEMOGRAPHIC TRENDS IN JAINA MONASTICISM

Table 12.8 Digambara ascetics in 2000 and 2001

\begin{tabular}{|c|c|c|c|c|c|c|c|c|c|c|}
\hline \multirow[t]{2}{*}{ Position } & \multicolumn{2}{|c|}{$\begin{array}{l}\text { Total } \\
\text { number }\end{array}$} & \multicolumn{2}{|c|}{$\begin{array}{l}\text { Number of } \\
\text { groups }\end{array}$} & \multicolumn{2}{|c|}{$\begin{array}{l}\text { Male } \\
\text { members }\end{array}$} & \multicolumn{2}{|c|}{$\begin{array}{l}\text { Female } \\
\text { members }\end{array}$} & \multicolumn{2}{|c|}{$\begin{array}{l}\text { All } \\
\text { members }\end{array}$} \\
\hline & 2000 & 2001 & 2000 & 2001 & 2000 & 2001 & 2000 & 2001 & 2000 & 2001 \\
\hline cārya & 5 & 51 & 51 & 51 & 237 & 213 & 12 & 128 & 35 & 341 \\
\hline xal & 4 & 4 & 3 & 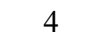 & 3 & 4 & 1 & 0 & 4 & 4 \\
\hline 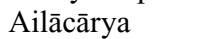 & 3 & 4 & 2 & 2 & 4 & 3 & 0 & 0 & 4 & 3 \\
\hline & 1 & 1 & 1 & 1 & 5 & 3 & 8 & 6 & 13 & 9 \\
\hline Myc & 16 & 20 & 12 & 18 & 22 & 25 & 1 & 0 & 23 & 25 \\
\hline Mur & 269 & 305 & 81 & 133 & 147 & 208 & 33 & 23 & 180 & 231 \\
\hline Saṇinī Āryikā & 10 & 8 & 5 & 5 & 2 & 2 & 31 & 31 & 33 & 33 \\
\hline ryikā & 312 & 325 & 41 & 67 & 0 & 0 & 162 & 194 & 162 & 194 \\
\hline & 26 & 29 & & 1 & 13 & 15 & 0 & 0 & & 15 \\
\hline & 80 & 94 & 19 & 3 & 20 & 35 & 0 & 0 & 20 & 35 \\
\hline Kṣullik & 46 & 63 & 6 & 12 & 0 & 0 & 7 & 12 & 7 & 12 \\
\hline Total & 818 & 902 & 232 & 341 & 453 & 508 & 365 & 394 & 818 & 902 \\
\hline
\end{tabular}

Source: A. Jain 2000: 1-27, 2001: 1-34.

whom Jaini estimates a third to be Digambar. On that estimate there is one muni for every 11 or 12 thousand Digambars' (ibid.: 221). ${ }^{264}$

According to the information on individual ascetics made available by B. U. Jain, the Digambara mendicants were 1987-1996 split into some 175 independent groups, including ascetics who wander alone. But B. U. Jain's figures on the Digambara ascetics are, in his own judgement, unreliable and inconsistent, due to insufficient self-reporting by the Digambara monks. ${ }^{265}$ Often, for instance, only the leader of an itinerant group is mentioned and not the total number of group members, which was simply estimated by B. U. Jain (1999: 382, n. 1-7) in his summary figures. However, his lists give some idea of the structure of the Digambara mendicant groups in the decade before the turn of the millennium and a rough estimate of the overall number of ascetics. ${ }^{266}$

A more precise annual cāturmāsa list, the Digambara Jain Sādhu-Sādhvīyom ke Varșayoga kī Sūcī, was compiled for the first time for the year 2000 by A. Jain of the Tīrthañkara Rṣabhadeva Jaina Vidvanta Mahāsangha in order to provide information for the laity 'who want to contact different saighas' (Letter 25 September 2002). The categories he used to compile complete alphabetical ${ }^{267}$ lists of groups (saìgha), ${ }^{268}$ names ( $s \bar{a} d h u / s \bar{a} d h v \bar{\imath}$, etc.), initiating monks ( $d \bar{l} k s \underline{\bar{a}}$ guru), and addresses of the monsoon retreats (cāturmās sthāl evam sampark sütra) of the Digambara mendicants in the years 2000 and 2001, confirm that the Digambaras effectively treat both nuns $(\bar{a} r y i k \bar{a})$ and novices who observe the eleventh śrāvaka pratima $\bar{a}^{269}$ - the ailakas, ${ }^{270}$ kșullakas, and kșullikās - as members of the ascetic community. The change of status is indicated by the changes of the name at the kṣullaka/kṣullikā dīksạ̄ and the muni dīkșā. Brahmacārīs and brahmacārin̄īs are not listed in the almanacs of A. Jain and B. U. Jain, because 
they are considered to be lay ascetics, although they sometimes accompany the wandering ascetics like novices. According to B. U. Jain (2002: 312), there are more than 100 brahmacārīs and 300 brahmacārin̄is today amongst the disciples of Vidyā Sāgar alone, and some, though very few, are still under the command of the bhattārakas.

Table 12.8 summarises the data published by A. Jain in 2000-2001. The ranking of the monastic positions ( pada) adopted by A. Jain indicates that the status of $\bar{a} r y i k \bar{a}$ s is generally considered to be higher than the status of ailakas and kșullakas. The status categories ācāryakalpa, ailācārya ${ }^{271}$ and bālācārya $a^{272}$ designate the most disciplined and learned munis and the chosen successor of an $\bar{a} c \bar{a} r y a$, whom he will consult in all important matters regarding the sangha. With or without the official permission of an àcarrya, members of all categories can form their own groups (sangha), which may comprise members from all lower status categories. ${ }^{273}$

There is only one a $\bar{c} \bar{a} r y a$ in every saingha. A Digambara ācārya acts independently. He either wanders alone or forms his own ascetic group (sangha), which usually includes munis, àryikās, kșullakas, kșullikās and sometimes one or two ailakas. In 2001, of altogether $51 \bar{a} c \bar{a} r y a s,{ }^{274} 14 \bar{a} c \bar{a} r y a$ s wandered alone and 37 lead small groups of 2-25 ascetics. Of the 37 group leaders, 5 wandered with only one other muni, 2 with one $\bar{a} r y i k \bar{a}, 18$ led small groups of up to 9 male and/or female ascetics, and only 12 formed groups with 10 or more members (A. Jain 2001: 1-11).

For practical reasons, larger groups are usually sub-divided into smaller units of itinerant ascetics. Even if they belong to the saingha of one and the same ācārya, most munis roam alone or in small bands of 2-5 male mendicants who spend their cāturmāsa together in one place. Arryikās, however, should never wander alone and travel always in company of laity. Sometimes they can be found in pairs, or they form larger groups of 4-20 nuns who wander together independently of the monks. However, in most sanghas the members of the central group surrounding the $\bar{a} c \bar{r} r y a$ are of mixed gender, and the male and female sub-groups travel and assemble together in public. They also stay at the same location for cāturmāsa, but reside in different buildings. ${ }^{275}$ In the year 2001, for instance, only 13 of the 37 groups that were led by a āarryas were composed entirely of men - notably the groups of the popular ācāryas Kunthu Sāgar and Vidyā Sāgar (A. Jain 2001: 1-11).

The large and centrally organised group of Ācārya Vidyā Sāgar is exceptional amongst the contemporary Digambara sanghas because of its size and influence. ${ }^{276}$ In the year $2001,20.8 \%$ of all Digambara mendicants were under the control of Vidyā Sāgar. Uniquely, the structure and demographic composition of Vidyā Sāgar's group in the years 2000-2002 can be precisely reconstructed from the accounts of A. Jain $(2000 \mathrm{~b}, 2001)$ and of B. U. Jain (2002: 309-12), who received comprehensive information for this particular Digambara saigha in the year 2002. Despite its exceptional status, the Vidyāsāgara Sañgha can serve as a paradigmatic example for the organisation of contemporary Digambara mendicant groups in general. From the year 1999 onwards, B. U. Jain's demographic figures for this sangha are said to be reliable (B. U. Jain 1996: 323, 1999: 372, n. 2). They show that in 1999 Vidyā Sāgar had 190 disciples and more than 50 
brahmacārīs and 150 brahmacārin̄īs (commonly called dīdīs: elder sisters) under his personal command, although the figures do not exactly correspond to the self-reported number of 195 members in 1999 (62 munis, 10 ailakas, 114 äryikās, 9 kṣullakas) (Ṭongyā 1999: 8). For 2001, the figure of 188 members (63 munis, 10 ailakas, 113 àryikās and 2 kșullakas) is reported by A. Jain (2001: 9-34). Because of the rapidly increasing membership of this group, the mendicants were distributed into 26 different sub-groups in 1996, 34 in 1999, and 44 in 2001, as reflected in the number of cāturmāsa residencies.

In the year 2002, the group had 183 members which were divided into 42 groups: 64 munis, 109 äryikās, 8 ailakas and 2 kșullakas (there are presently no kṣullikās in Vidyā Sāgar's sarigha). ${ }^{277}$ The munis were divided in seventeen units. ${ }^{278}$ The majority (37) stayed together with Ācārya Vidyā Sāgar, 9 munis formed groups of three, 10 munis groups of two and 7 wandered alone. The 3 ksullakas and 6 of the 8 ailakas - which are considered to be superior to the $\bar{a} r y i k \bar{a} \mathrm{~s}$ in Vidyā Sāgar's order - wandered alone. ${ }^{279}$ The $\bar{a} r y i k \bar{a} \mathrm{~s}$ were divided into 16 groups of 2-17 members, who roamed independently from the male mendicants. Male and female mendicants never wander together or spend cāturmāsa at the same location in order to maintain the reputation of this saigha for strict standards of conduct (B. U. Jain 2002: 312). ${ }^{280}$

Due to the large number of sub-units, the sangha commanded a vast geographical sphere of influence, covering Madhya Pradeś (20 sub-divisions), Mahārāștra (5), Rājasthān (4), Hariyāṇā (2), Uttar Pradeś (1) and Karṇātaka (1). At the same time, almost half of all munis and half of all äryikās spent cāturmāsa together in one single location in Madhya Pradeś and Mahārāstra respectively. ${ }^{281}$ These states are the two main recruitment areas for the Vidyā Sāgar Sangha. With few exceptions, all disciples of Ācārya Vidyā Sāgar come from Mahārāștra, Madhya Pradeś and Uttar Pradeś, although he himself was born in Karṇātaka. Similar patterns of a nationwide mission starting from a regional base can be observed amongst the Śvetāmbara Terā Panthīs and amongst other contemporary Jain orders.

As a rule, all Digambara ascetics associated with the muni sangha are initiated by an $\bar{a} c \bar{a} r y a$ or with his permission. ${ }^{282}$ Indeed, all members of the Vidyāsāgara Sangha today have been initiated by Vidyā Sāgar himself. Arryikās are also by rule always initiated by an ācarrya and should never constitute entirely autonomous orders, although they do not always move around with the munis. ${ }^{283}$ Within a sangha led by an $\bar{a} c \bar{a} r y a$ the munis and $\bar{a} r y i k \bar{a}$ s remain under the control of the $\bar{a} c \bar{a} r y a$ who initiated them. However, though a ganinī has a lower status than a muni, under certain circumstances an $\bar{a} c \bar{a} r y a$ will appoint a qualified nun as the leader of all the $\bar{a} r y i k \bar{a}$ in his sangha, while the munis remain always under the direct control of the $\bar{a} c \bar{a} r y a$. As amongst most Śvetāmbara orders, in the absence of an ācārya, the head of the àryikā gaṇa, the ganinī, will act like an ācārya for the āryikās.

Sometimes, ganinīis or āryikās are given permission by the ācārya to initiate their own female disciples. ${ }^{284}$ The lists of A. Jain for the year 2001 show that 4 gaṇin̄is had initiated altogether $16 \bar{a} r y i k \bar{a} \mathrm{~s}$ and $4 k s ̣ u l i k \bar{a} \mathrm{~s}$, and $4 \bar{a} r y i k \bar{a}$ s initiated altogether $8 \bar{a} r y i k \bar{a}$ s. There are evidently also male ascetics who performed 
initiations independently. In 2001, 1 upādhyāya and 2 munis initiated altogether 6 àryikās. One ailaka, 7 kșullakas, and one kșullikā were also initiated by various ācāryakalpas, ailācāryas and munis - with or without the permission of an $\bar{a} c \bar{r} r y a .{ }^{285}$ Occasionally, even self-initiations of munis are reported. ${ }^{286}$

The monastic names of the āryikās always have the double suffix -matī mātā at the end. The ganinīs are called ganinī āryikā śrī [name] mat̄̄ mātā jī. The gaṇin̄̄ pramukha Āryikā Jñān Matī and her namesake Āryikā Jñān Matī (Gujarāt), have each one kșullaka amongst their disciples. However, the kșullakas were not initiated by the āryikās themselves but by Ācārya Vimal Sāgar and by Ācārya Ajit Sāgar respectively. ${ }^{287}$ According to Shāntā (1985: 514f.) and Balbir (1990: 182f.), the prominent Āryikā Jñān Matī (born 19 October 1933) was initiated by the late Ācārya Deś Bhūṣaṇ. However, D. Śāstrī (1985: 150) points out that only her kṣullikā dīkṣa was performed by Deś Bhūṣan in 1953, but her āryikā dīkṣa by Ācārya Vīr Sāgar in 1956. After his death, Jñān Matī was associated with the late Ācārya Sumati Sāgar. She now commands her own separate group, which is largely composed of family members but includes also celibate male lay followers ( $\mathrm{brah}$ macāri $)$ who were personally initiated by her in 1987 - the first event of its kind. Due to health reasons, she stays more or less permanently in her abode in Hastināpur, where her followers have built a giant cosmographic model of the continent Jambūdvīpa in concrete. ${ }^{288}$ She is closely associated with the Mahāsabhā and with the opponents of the cosmological interpretations of the Kānjī Panth. ${ }^{289}$

Even the largest Digambara sanghas have a flat administrative structure, which confirms that formal organisation does not play a prominent role in Digambara monasticism. The guru-śisya link alone constitutes the institututional core of the Digambara mendicant traditions. This is reflected in publications such as D. Sāstrī's (1985) Digambara Jain Sādhu Paricay, which lists only the immediate disciples of a muni, but does not depict any lineages. Of the 37 groups led by $\bar{a} c \bar{a} r y a$ s, only 5 comprise another office-holder apart from the ācārya himself. The majority of these 5 groups are not even particularly large, which suggests that the titles (2x upādhyāya, $2 \mathrm{x}$ ailācārya, $1 \mathrm{x}$ ganinī $)$ designate honorary rather than administrative roles. The dedicated successors of an $\bar{a} c \bar{a} r y a$, the ācāryakalpas, ailāāaryas or yuvācāryas ${ }^{290}$ bālācaryas and upādhyāyas, are usually permitted to form their own groups and to initiate their own disciples, while continuing to respect the moral authority of their $d \bar{\imath} k s \underline{a}$ guru. Because of his limited powers, an $\bar{a} c \bar{a} r y a$ cannot prevent his disciples leaving, if they are supported by members of the lay communities. ${ }^{291}$ Although, in principle, only an ācärya can convey the titles of ācāryakalpa, ailācārya, bālācarya, or upādhyāya or gaṇin̄i on highly respected monks or nuns, ${ }^{292}$ there are several recognised methods for becoming an $\bar{a} c \bar{a} r y a$ : either by the choice of the acting $\bar{a} c \bar{a} r y a$, or - if the $\bar{a} c \bar{a} r y a$ dies without having determined a successor - by the choice of the muni sangha ${ }^{293}$ and/or the $\operatorname{sam} \bar{a} j$, or by the acclamation of a self-selected successor (e.g. the oldest disciple). In practice, the laity always interfere in the decision making process. Often, individual monks sever themselves from their $\bar{a} c \bar{a} r y a$ s and simply declare themselves to be $\bar{a} c \bar{a} r y a \mathrm{~s}$ in their own right. However, most ācāryas, even those 
who command their own disciples, remain nominally part of the lineage of their teacher, although 'there is no formal recognition of a line of pupillary succession' (Carrithers 1990: 153). In the absence of clear organisational and disciplinary rules (mary $\bar{a} d \bar{a})$ - there are no established criteria for initiation and excommunication (which is never practised) - the group structure and the personnel of the peripatetic groups of a Digambara muni sarigha is in perpetual flux. Changes occur not only through temporary visits in other groups for purposes of study, but also through the inflow and outflow of new mendicants from one saingha to another, and through the deliberate division of a large group into smaller groups for convenience by the $\bar{a} c \bar{a} r y a$ s. It is therefore doubtful whether descent constructs are of practical importance beyond the purpose of legitimisation qua tradition. However, the doctrinal differences between the group of Vidyā Sāgar, who promotes idiosyncratic Terā Panth teachings, and the majority of the other Digambara $\bar{a} c \bar{a} r y a \mathrm{~s}$, sometimes causes the rejection of the munis of one lineage by another.

\section{Demographic trends}

According to the data collected by A. Jain, the total number of Digambara ascetics increased between 2000 to 2001 by $10.3 \%$ or 84 mendicants, within a single year. The category with the greatest increase is the one of the munis, who are responsible for the higher growth rate of male rather than female ascetics. In the year 2000, the 450 male ascetics represented 55\% of all Digambara ascetics, the 368 female ascetics $45 \%$, and in the year 2001 the 508 male ascetics represented $56.42 \%$ and the 394 female ascetics $43.7 \%$. In 2001, the totally 902 ascetics were distributed over 341 groups. The average group size was only 2.65 (a $r y i k \bar{a}: 2.9$ ). However, the average size of the groups (sarigha) of the ācāryas was 6.9, which reflects their importance for the organisation of the Digambara ascetics. The fissiparous tendencies of the Digambara ascetics are illustrated by the fact that the groups led by $\bar{a} c \bar{a} r y a$ s lost 18 members altogether within one year, whereas the groups led my munis and $\bar{a} r y i k \bar{a}$ s gained 51 and 32 members respectively.

The data published by B. U. Jain (1999: 382) show that the Digambara as a whole have by far the highest growth rate of all Jain mendicant traditions, even if we take into account that the nominal statistical growth largely reflects underreporting in earlier years. ${ }^{294}$ Within 12 years, the reported numbers have almost tripled from a total of 363 in 1987 to a total of 960 in 1999. The overall trend has been confirmed by the reliable information of A. Jain for the years 2000-2001. This growth is all the more astonishing considering the fact that one of the first modern munis, Ādi Sāgar, who died in 1943, initiated himself as late as 1913. The accelerated increase in numbers started even later, after Sānti Sāgar's death in 1955, when the Digambara laity began to actively encourage the initiation of munis (Kāsalīvāl 1992: 35). Two explanations for the revival of the muni sarigha are generally offered by the Digambaras: The abolition of the limitations imposed by both the colonial government and local kings on the free movement of the naked ascetics after Indian Independence, and the lack of any examination of the 
qualifications of the candidates because of the absence of organisational rules. Critics noted that the artificial increase of numbers due to the unchecked intake resulted in diminishing standards of conduct amongst the munis, many of whom joined the mendicant life 'mainly to gain influence and to enrich themselves' and to leave again as they please. ${ }^{295}$ This argument is rejected by others, who point out that, if this would be true, then even more initiations would take place. Instead, the inspirational role of family members who became munis is highlighted, and the effects of the renaissance of Jain religious education in the last 100 years. Economic factors are generally discredited with reference to the fact that the main recruiting grounds for munis in northern Karṇạtaka and southern Mahārāṣtra, and elsewhere, have experienced considerable economic growth over the last decades.

The most interesting result of this preliminary demographic analysis of the Digambara mendicants is that the Digambaras are the only contemporary Jain tradition which has more monks than nuns (monks 1986: 86.89\%, 1990: 63.38\%, 1995: 54.13\%, 1998: $54.25 \%$ and 1999: $63.54 \%) .{ }^{296}$ Part of the explanation for this must be sought in the Digambara doctrine of the spiritual inferiority of women, which is naturally unappealing for unmarried girls who may perceive monastic life as an alternative to marriage (Jaini 1991: 26). Yet, for all practical purposes, Digambara āryikās have more personal freedom than Mūrtipūjaka $s \bar{a} d h v \bar{\imath} \mathrm{s}$, and their numbers are currently increasing. Another factor may be the lack of institutional structures, which offer protection to nuns. ${ }^{297}$

\section{Jaina mendicants 1987-1999}

The total number of Jain mendicants for the period between 1987 and 1999, and the relative size of the four principal mendicant traditions are summarised in Table 12.9 and Table 12.10. According to the figures published by B. U. Jain, 11,737 Jain sādhus, ailakas, kșullakas, sādhvīs and āryikās have been counted in 1999. This total is based on confirmed figures only, excluding the personal estimates by B. U. Jain. The real number of mendicants was certainly higher, maybe between 100-300, disregarding yatis, bhațāarakas, brahmacārīs and brahmacāriṇīs.

The figures illustrate the continuing numerical dominance of the Mūrtipūjaka ascetics and particularly of the Tapā Gaccha mendicants, who retained more than $50 \%$ of the overall share. A look at the summary figures for 1999 and a comparison with those of 1987 shows that the ratios of the main sectarian schools remain relatively stable, considering the significant underreporting of the number of Digambara ascetics before 1996. In 1987, 59.37\% of all mendicants were Mūrtipūjakas and 52.28\% belonged to the Tapā Gaccha, and in 1999, 58.30\% were Mūrtipūjakas and $51.51 \%$ belonged to the Tapā Gaccha. The percentages of the Sthānakavāsīs and the Terā Panthīs - whose rapidly increasing number of saman̄is was not taken into account in the statistics - fell slightly; in the case of the Sthānakavāsīs, from $29.03 \%$ in 1987 to $27.46 \%$ in 1999 , and in the case of the Terā Panthīs, from $7.66 \%$ in 1987 to $6.06 \%$ in 1999 . By contrast, the share of the 


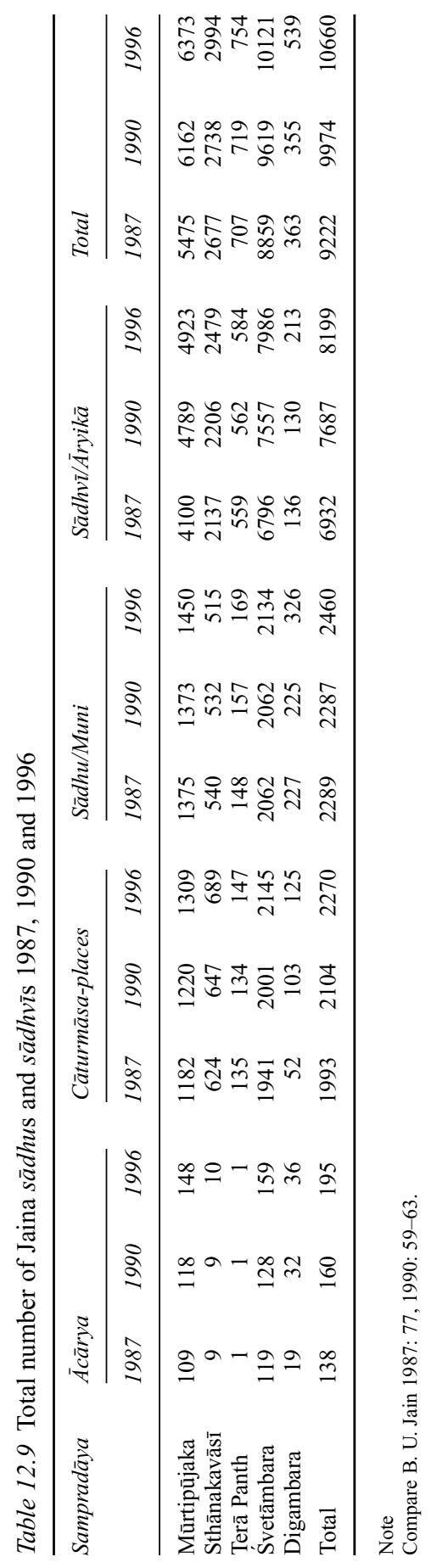


PETER FLÜGEL

Table 12.10 Total number of Jaina $s \bar{a} d h u$ s and $s \bar{a} d h v \bar{\imath} \mathrm{s} 1999^{\mathrm{a}}$

\begin{tabular}{|c|c|c|c|c|c|c|}
\hline Sampradāya & $\bar{A} c \bar{a} r y a$ & $\begin{array}{l}\text { Cāturmāsa- } \\
\text { places }\end{array}$ & Sādhu/Muni & Sādhvī/Āryikā & Total & $\%$ \\
\hline Mūrtipūjaka & 164 & 1485 & 1489 & 5354 & 6843 & 58.30 \\
\hline Sthānakavāsī & 9 & 768 & 533 & 2690 & 3223 & 27.46 \\
\hline Terā Panth & 1 & 128 & 154 & 557 & 711 & 6.06 \\
\hline Digambara & 40 & 190 & 610 & 350 & 960 & 8.18 \\
\hline Total & 214 & 2571 & 2786 & 8951 & 11737 & 100 \\
\hline
\end{tabular}

Digambaras rose sharply from $3.94 \%$ in 1987 to $8.18 \%$ in 1999 for the reasons given earlier.

A comparison of the data from 1987 and 1999 shows that the total number of Jain mendicants has increased from 9,222 in 1987 to 11,737 in $1999 .{ }^{298}$ The overall growth rate for the twelve year period 1987-1999 was an astonishing 26.75\%: Mūrtipūjaka 24.99\%, Sthānakavāsī 20.40\%, Terā Panth 0.57\% (1987-1996: 6.65\%) and Digambara 164.46\%. The growth rate would have been even higher if the sharply rising number of novices and lay ascetics had been taken into account. ${ }^{299}$

The accelerated increase in the number of Jain ascetics in recent years contrasts with the slow growth of the Jain population as a whole, which rose between 1981 and 1991 by $4.98 \%$, from 3.193 million to 3.352 million. Apart from the Zoroastrians, the Jains had by far the lowest relative growth rate of all Indian religions (4.42\% between 1981 and 1991, 26\% between 1991 and 2001), which reduces their share of the total population from $0.48 \%$ in 1981 to $0.40 \%$ both in 1991 and 2001 (cf. M. K. Jain 1986: 33f., Vijayanunni 1991: x-xi, www. censusindia.net). The divergent growth rates of the mendicants and the lay population indicate an increasing popularity of monastic life for the period under investigation. ${ }^{300}$ This is a puzzling fact, especially if one assumes that secularisation and religious decline are two sides of the same coin. Cort (1989: 100, n. 16) remarked that the continuing rise of the numbers of Jain mendicants is a 'quite striking phenomenon... given the economic and social status and the degree of Westernisation of Jain society'. If the data is correct, our pre-conceptions need to be revised. Apparently, westernisation and modernisation have not contributed to a decline, but to an increase in the popularity of renunciation amongst Jains.

\section{Reasons for renunciation}

How can we explain this? There is no easy answer. One explanation would be to argue that renunciation became more popular as a consequence of the monastic reforms at the beginning of the twentieth century, which improved the standards 
and therefore the appeal of monastic life. A social psychological perspective, on the other hand, would focus on the function of the institution of renunciation as a socio-cultural defense-mechanism which compensates for the disruptive effects of modernisation and socio-economic change. ${ }^{301}$ We can, for instance, observe a strong rise in the number of male mendicants during the struggle for national independence and in the first years after Indian independence, when Gāndhī's influence reached its zenith. During these years, male mendicants in particular were attracted both by the political utility of the cultural symbolism of renunciation for the purpose of social integration and by the social activism of reform-orientated Jain ācarryas. But this interpretation does not account for the unprecedented popularity of renunciation in the last two decades.

Another argument points to the recent economic success of the Jain community, which enables it to lose some male workforce and to sustain larger mendicant communities. This point is sometimes raised within the Śvetāmbara Jain community. The absolute number of Jain mendicants is very small, compared to Buddhism which has at least 300,000 fully initiated bhikkhus worldwide ${ }^{302}$ or Christianity which still has more than 1,000,000 monks and nuns. ${ }^{303}$ However, the proportion of mendicants relative to the Jain population as a whole is higher than amongst Buddhists or Christians, and probably always was. In 1990 the ratio was 1 mendicant for every 336 laity (9,974 mendicants: 3,352,706 laity). This extraordinary high ratio of mendicants may indeed be explained in terms of the wealth of the Jain population, which can easily afford to feed such a big mendicant community.

Another explanation is given by Goonasekere (1986: 118f.), who interprets Jain renunciation as an institutionalised protest movement against specific social constraints within the status-conscious baniyā castes in Western India. Yet, this variant of the deprivation theory which explains the higher proportion of mendicants from families with a relatively lower income from a rural or small town background ${ }^{304}$ with reference to economic difficulties and the resulting psychological tensions ${ }^{305}$ does not account for the motivation of the monks in his own sample, who cited charismatic attraction to a monk or nun as the main factor. As we have seen, the recent accelerated increase of Digambara munis is sometimes explained by members of the Digambara community itself by the lack of disciplinary procedures within the Digambara mendicant orders and by the opportunity for young men from the relatively poor Digambara agricultural castes in South India to increase their status and power by joining one of the sarighas. However, if these were the only reasons, then even more young men would renounce. ${ }^{306}$

The main reason for the rapidly growing popularity of monastic life must be sought amongst the population of male Digambara and female Śvetāmbara renouncers. One of the most interesting findings is the continuing predominance of the male ascetics amongst the Digambara, which reflects the different status of nuns in this tradition. Amongst the Śvetāmbaras, only the Tapā Gaccha Bhuvanabhānusūri Samudāya has - for the said reasons - also more $s \bar{a} d h u$ s than $s \bar{a} d h v \bar{\imath} s$. Śvetāmbara Jainism is unique, because of the institutionalised option of 
PETER FLÜGEL

Table 12.11 Percentage of $s \bar{a} d h v \bar{\imath} \mathrm{s}$ 1987-1999

\begin{tabular}{llllll}
\hline Year & Mūrtipūjaka & Sthānakavāsi & Terā Panth & Digambara & Total \\
\hline 1987 & 74.88 & 79.83 & 79.07 & 37.46 & 75.17 \\
1990 & 77.72 & 80.57 & 78.16 & 36.61 & 77.07 \\
1996 & 77.25 & 82.80 & 77.45 & 39.52 & 76.91 \\
1999 & 78.24 & 83.55 & 78.92 & 36.46 & 76.30 \\
\hline
\end{tabular}

full ordination for women, which is neither offered by Hinduism nor Theravāda Buddhism. ${ }^{307}$ Why is the percentage of female Jain mendicants presently rising? A comparison of the percentages of the sādhvis between 1987 and 1999 shows a significant $(>3 \%)$ increase in the number of female ascetics amongst the Mūrtipūjakas and Sthānakavāsīs, while the ratios of the Terā Panthīs and the Digambaras remained stable for the reasons cited earlier (Table 12.11). Sthānakavāsīs have the highest percentage of female mendicants, most certainly because they allow the greatest degree of freedom for $s \bar{a} d h v \bar{\imath} s$, who are permitted to read all scriptures, to preach, and to roam separately. However, the overall ratios between $s \bar{a} d h u$ s and $s \bar{a} d h v \bar{\imath} \mathrm{s}$ remained not only relatively stable between $75 \%$ and $77 \%$, they also roughly corresponded to the percentage of $72 \% s \bar{a} d h v \bar{l} s$ quoted in the Kalpa Sūtra.

Social reasons, such as widowhood, unmarritability, high dowry claims amongst higher castes, ${ }^{308}$ and other experiences of institutionalised social constraints have been cited already by Bühler and others, ${ }^{309}$ in order to account for the consistent popularity of renunciation amongst Jain women. But this does not explain either the absence of female renunciation in similar social groups or recent developments. Reynell (1985: 269) pointed to the rising age of marriage in the Jain communities. Following on from Goonasekera (1986), Cort (1991) diagnosed 'drastic changes in the demographics of Śvetāmbar mendicancy' (ibid.: 659), from 'a situation not unlike the traditional Brāhmanical prescription for the vanaprastha and saninyāsa āśramas, the stages of gradual withdrawal and renunciation after the householder (grhastha) stage of life', to a pattern in which 'the vast majority of contemporary ascetics are unmarried and take $d \bar{\imath} k s \underline{a}$ before the age of thirty' (ibid.: 660). He sees the improvements in the social world of women as the reason for the declining number of widow mendicants during the twentieth century. He argues that because nowadays most widows are likely to have had children - due to the rise in the age of marriage and rising health standards - they are less inclined to renounce than child widows in the nineteenth century: 'Having to raise the children means that becoming a $s \bar{a} d h v \bar{\imath}$ is less of a realistic option for a widow. Changing social attitudes towards widows also make it less likely that a Jain widow feels that she has little choice but to become a $s \bar{a} d h v \vec{\imath}$, (Cort 1989: 111f.). Therefore, 'becoming a $s \bar{a} d h v \bar{\imath}$ is now seen as an alternative vocation to that of a housewife' (ibid.). ${ }^{310}$

This theory certainly explains the declining number of widows within the mendicant orders, but not the increasing number of unmarried women. Why should 
more and more young Jain women become disillusioned with family life under conditions of increasing prosperity and personal freedom? An important factor, which has not been considered thus far, is the significant change in the standard of education of Jain women. One hundred years ago, most Jain women were illiterate. Yet, the last Census of India in 2001 recorded a female literacy rate of 90.6 per cent amongst the Jains - the second highest after the Parsis - while in India as a whole it was only 47 per cent. Contemporary Śvetāmbara women are often born into privileged social groups and increasingly able to enjoy higher education, to choose their husbands within given limits but rarely to give up housework for an independent professional career, unimpaired by customary constraints. Formal education and the experience of an extended period of pre-marital independence often raise expectations which make it difficult for young educated women to re-adjust to the lifestyle of a traditional Jain housewife.

The experience of small freedoms generally increases the desire for more. Yet, monastic life does not offer more individual freedom, but an even more disciplined and restrained way of life. Socio-economic reasons for renunciation are recognised as a matter of fact but not condoned by the Jain scriptures (Thānā 712a, 335a, Schubring 2000, § 137) and can only offer a partial explanation to a difficult question. A more complete answer must take into account multiple factors, in particular the motivating role of the Śvetāmbara doctrine of salvation and the opportunity of an alternative lifestyle offered by the existing $s \bar{a} d h v \bar{\imath}$ traditions themselves, as well as the elevated individual status of a nun in the Jain community. I think the most likely candidate for further exploration is the romantic image of freely roaming female ascetics, who enjoy enhanced conditions of living in reformed and materially well supported mendicant orders which offer opportunities for education and self-development that are still unavailable in traditional family life, which currently catches the imagination of young Jain women, ${ }^{311}$ in the same way as men were attracted by the political symbolism of renunciation during the independence struggle. ${ }^{312}$

\section{Concluding remarks}

The most interesting result of this study, however preliminary it may be, is the emerging, nearly complete, pattern of the group structure of the current Jain mendicant traditions. The Digambara muni tradition is currently divided into some 341 itinerant groups and individuals, who belong to three lineages and maybe a dozen sub-lineages which have a flat administrative structure. However, more than half of all Digambara mendicants were initiated and are supervised by only a handful of $\bar{a} c \bar{a} r y a s .{ }^{313}$ Although the Digambara tradition has currently no monastic orders, nor clearly identifiable schools and sects, it shows significant organisational and doctrinal faultlines which deserve further investigation. In total, the Śvetāmbara tradition is composed of some 57 independently organised groups: 27 Mūrtipūjaka, 26 Sthānakavāsī and 4 Terā Panth. These independently organised 'orders', together with their lay followers can be designated as 
sociological 'sects', in contrast to doctrinal 'schools', although some overlap and fluid transitions between the three categories occur. There are, of course, fewer doctrinal schools than orders and sects. The principal schools of the Mūrtipūjakas are the six gacchas. The situation amongst the Sthānakavāsīs is more diffuse, since not all of the 5 founding fathers had major doctrinal differences. However, there are at least two broad schools within the Sthānakavāsī movement. On the one hand, those who follow the teachings of Dharma Sinha, who may have had a significant, though never acknowledged, influence on the Terā Panth ācārya Bhiksu and his idiosyncratic teachings, and, on the other hand, those who follow the teachings of Lava and Dharma Dāsa, who had only minor disagreements. The few globalising mendicant groups on the fringe of the Sthānakavāsī movement, which allow their ascetics to use modern means of transport and travel abroad, represent a new development, and share many attributes with Jain lay movements with the yati traditions, and with the disdained mendicants 'who wander alone' (Pkt. egalla vihārī), who can always be found on the fringes of the organised Jain ascetic traditions. ${ }^{314}$ The use of modern means of transport might in future significantly modify the relationship between group size and size of lay following. However, the use of modern means of communication which, in contrast to the modern means of transport, are now endorsed by most, but not all, mendicant groups, has presently no significant influence on the pattern of recruitment of devotees, which continues to be predicated on regular personal contact between guru and devotee.

\section{Acknowledgement}

I am very grateful to Professor Padmanabh S. Jaini for his comments on an earlier version of this study.

\section{Notes}

1 Throughout the text, the colloquial 'Jain' rather than 'Jaina' is used, and with the exception of the Sanskritic names of sects and schools and technical Jain terms, proper names are not sanskritised.

2 See the volume Village India edited by McKim Marriott in 1955. Survey techniques were first used in Jaina Studies by Sangave 1959/1980, whose literature review on the social divisions of the Jains is still the standard reference source. The first book length field studies were the monographs by Mahias 1985 and Shāntā 1985. Regional, subaltern, media, etc. studies have yet to be applied on a larger scale in the emerging field of Jaina Studies.

3 'Jains', 'lay Jains in a particular location', 'Mūrtipūjaka/ Digambara Jain laity', 'Jain mendicants', 'Jain merchants', 'Jain women', 'Jain nuns', etc.

4 Following Schubring 2000: §139, 252, Folkert 1993: 153, 163 translates the ambivalent terms gaccha and its Digambara equivalent sangha variably as 'school', 'sect' and 'order'. He defines schools as 'doctrinally' demarcated units, sects as 'modern', and monastic orders as primarily concerned with issues of 'praxis'. Balbir 2003: 48 focuses only on 'orders' or 'lineages' - the terms are used as synonyms - and dismisses the doctrinal dimension as insignificant with regard to gacchas. However, 
many orders are doctrinally demarcated, as Balbir's study of doctrinal controversies concerning proper praxis shows; and even in the pre-modern period sects existed with and without core monastic orders. For alternative definitions of the terms school, order and sect see Flügel 2000: 77f. and note 8.

5 For a similar research strategy see Banks 1986: 458 and Flügel 1994: 4, 1995-96: 119, n. 4.

6 See also Cort in this volume, p. 261.

7 Sangave's 1959/1980 attempt at conducting a representative survey did not meet sufficient response from the Jain community.

8 It is neither possible nor methodologically desirable to find for every Jain (Indian) term an equivalent analytical term and vice versa. I would propose to define Jain schools, orders and sects in the following way (cf. Flügel 2000: 42, n. 9). Doctrinal 'schools' may inform both individuals or (un-) organised religious 'movements' of various types; organised monastic 'orders' contrast with unorganised ascetic groups and ascetics who 'wander alone' (ekala vihärī); 'sects' are exclusive groups which either (a) encompass both ascetics and laity, that is the classical four-fold community (caturvidha sangha) and variations created by added intermediary categories such as the pañcavidha sangha etc. or by the deliberate exclusion or factual absence of one or more of the four categories, or (b) represent self-conscious lay movements. Corresponding to the distinction between orders and sects is the distinction between the casual 'supporter' of the ascetics, the initiated (through the vow of allegiance) or simply dedicated lay 'follower', and the born and/or paying 'member' of a sect-specific Jain caste- or community organisation. See Flügel 1994: 404; and Dundas' 2003: 129 for the differentiation between 'affiliation' and 'conversion'. For the distinction between Indian monastic 'orders' and 'sects' which encompass both ascetics and laity see Vallée-Poussin 1918: 716. The peculiar dual organisation of the majority of the contemporary Jain (and other Indian) 'sects', with monastic orders as a core supported by amorphous lay communities under the spiritual command of the monks, was also highlighted by Max Weber 1920/1978: 207. See Dumont's 1980: 284 distinction between the doctrinal exclusivity of an Indian 'sect' and its social inclusivity. Generally, social categories, organised groups and gatherings need to be distinguished..

9 It seems advisable to distinguish the level of more or less exclusive 'schools', organised 'sects' and 'movements' from the level of the two principal religious 'denominations' in Jainism which Leumann 1934: 1 called 'Confessionen'.

10 The use of the word 'Jaina' as a self-designation for both the monastic community and the lay community is a relatively recent one (Böhtlingk and Roth 1861: 132, Flügel 2005: 3f.). In the ancient texts, the words niggamtha and niggamthi referred only to Jain monks and nuns, but not to their followers, or upāsakas (Jacobi 1879: 5), who were classified as part of the four-fold saigha only from the late-canonical period onwards by both the Śvetāmbaras (Viyāhapannatti 792b, Thāna 281b) and by the early Digambaras (Mūlācāra, Chappāhuḍa, etc.) (Schubring 2000, §30, § 137).

11 Between 1871 and 1891, the Census of India gradually substituted the initial classification of the Indian population in terms of religion with a dual religion/caste classification: 1871: 'Hindu', 'Muslim', 'Other', 1881: 'religion (caste)', 1891: 'religion (sect)', 'caste (sub-caste)' (Baines 1893: 186f.). 'The ... change was made in order to get rid of the notion that caste, or social distinction, was not required for Musalmans, Sikhs, Jains, and so on, or was held to be subordinate in any way to sect or religion' (ibid.: 187).

12 Brekke 2002: 129-132, cf. Dundas 2002: 4-6, Flügel 1994: 11-15.

13 'Many Jains have ... undoubtedly given their religion as Hindoo, and in some cases, though these are not many, I am inclined to think the enumerators have returned as Hindoos persons who really stated their religion to be Jain. As the followers of the 


\section{PETER FLÜGEL}

Jain creed are generally held and themselves generally claim, to be Hindoos, this is not surprising: nor is this error of importance, for the domestic and social economy of the Jains differ little from the orthodox Hindoo' (Plowden 1883: 23, cf. Kitts, in Plowden 1883: 19f., Baines, in Plowden 1883, III: cvii). See Cohn 1992: 248, Sangave 1980: 3, Dundas 2002: 4-6, Carrithers 2000: 833f.

14 The main reason for the ambiguous self-identification of many Jains is the equivocal nature of the concept 'Hindu' itself.

15 For example, Keshroy 1924, Maṇilāl 1934: 270f., Natarajan 1971 I: 39. The preface of Singh's 1894: 1 report on the census of 1891 in Marwar states that in addition to the questionnaire of the census supervisors and inspectors 'a good many facts were investigated through personal enquieries from trustworthy representatives of various communities'.

16 There is no evidence for the inflated estimates that are frequently quoted in popular Jain publications. Kalidas Nag wrote in his speech to a Jain audience, 'Jainism - A World Religion', in the Jaina Gazette 57, 2-3 (1951): 'You should prepare a census of your own, regardless of the government census, to arrive at a correct conclusion' (ibid.: 35). Earlier attempts to produce community censuses, such as the Jain Śvetāmbara Directory (Gujarāt) written in Gujarātī (Jain Śvetāmbara Conference 1909, 1915, 1916), were lacking an integral 'Jain' communal or communitarian perspective. The first Jain Śvetāmbara Directory was produced between 1906 and 1907 in accordance with resolution No. 8 of the Jain Śvetāmbara Conference in 1904 which called for the collection of information on the followers of the different Mūrtipūjaka and 'Lonkāgaccha' Śvetāmbara gacchas and samudāyas in all districts (jillā), sub-districts (tāluka) and villages ( $g \bar{a} m a)$ in India. The book was intended in particular as a travel guide, for instance for pilgrimages $(y \bar{a} t r \bar{a})$. With the help of local volunteers a questionnaire was distributed by the main coordinators Śobhacand Mohanlāl Śāh and Dāhyācand Trībhovan Gāndhī, who listed the following categories: the number of family houses (kula ghara), women (strī), men (purūṣa), caste (jñāti), sect (gaccha), literacy; and the local temples (jina-mandīra), images (jina-pratimā), monasteries (upāśraya), libraries ( jũāna-bhaṇ̣̂āra), schools (pāṭhśālā), old books ( pūrvācārya pran̄ita grantha), Jain societies (sabhā) and associations (mandala). The interesting resulting statistics suffer from imprecise lists of jūatis and gacchas and problems of inaccurate self-reporting and counting, as the compilers of the first report emphasise (Jain Śvetāmbara Conference 1909: ii-iii). It was probably in response to the Śvetāmbara efforts that the eleventh meeting of the Digambara Jain Mahāsabhā inspired Mānikcand Hīrācand Jauharī of Bombay to produce between 1907 and 1914 the Shri Bharatvarshiya Digambara Jain Directory (Jhaveri 1914) 'for the good of all Digambara Jain brothers'. The ensuing publication contains lists of towns, leading community members, caste, professions, etc. Cf. Sangave 1980: 119-121, 124-130. I am grateful to Yashvant Malaiya, who has pointed this source out to me. Nowadays, excellent self-produced national statistics are available for certain castes, such as the Khandelvālas, which have a high proportion of Jain members.

17 A Digambara Jain layman told me that the results of the Census of India of 1981 and 1991 in North Indian states were manipulated by 'Hindutva' inspired enumerators who wrote 'Hindu (Jain)' into the forms, even if the answer given was 'Jain'. During the Census of 2001, Jain community leaders started awareness rising campaigns to prevent a recurrence of these practices.

18 The introduction of a question on religious affiliation into the UK-census of 2001 stirred similar sentiments amongst leading members of the Jain community in Britain. For a Hindutva inspired variation of demographic angst regarding the outgrowth of the Hindus by the Muslims in India see A. P. Joshi et al. 2003.

19 B. U. Jain 1999, for instance, lists the Mūrtipūjaka samudāyas according to their size. See Appadurai 1993: 117 on the role of numbers for the colonial 'illusion of 
bureaucratic control'. The role of numbers (regarding fasts etc.) is even greater in traditional Jainism.

20 Jacobi 1884: 267, n. 1, Schubring 2000 § 22: 44. Sharma 1999: 78f. noted that Ācārya Hemacandra's 12 th C. Trișaștíśalākāpuruṣacaritra associates varying numbers of monks, nuns and laity with different Jinas.

21 Cf. Jaini 1991: 25.

22 Plates 13-15 in A. Cunningham's Archaeological Survey Report 20.3, in Bühler 1887: 169 .

23 Sthavirāvalī 5, in Jacobi 1884: 289.

24 Sangave now seems to prefer the less charged term 'communitarianism' (personal communication, 2 January 2005).

25 Cort 1989: 491-94 summarised B. U. Jain's demographic data of the Mūrtipūjaka $s \bar{a} d h u$ s and $s \bar{a} d h v \bar{s} \mathrm{~s}$ in 1986 in an appendix, but noted their incompleteness, which was partly rectified by B. U. Jain's subsequent publications.

26 These are the conventional dates. Except in the case of the 'panths', I have represented the names of monastic orders in their sanskritised form, but proper names in their spoken form.

27 The primary source of information on the origins of these groups is the Pravacanaparīkșā of the sixteenth century Tapā Gaccha upādhyāya Dharma Sāgara. For an overview of their history, doctrines and practices see M. U. K. Jain 1975.

28 The patțāvalīs of the Kharatara Gaccha and of the A(ñ)cala Gaccha were published in many Sanskrit and vernacular editions. They were studied by Klatt 1894 and by Sivprasād 2001. See also Pārśva 1968: 9-21.

29 The Gacchādhipati of the A(ñ)cala Gaccha is presently Śrīpūja Moti Sāgar Sūri (born 1944). See Photographs. The Śvetāmbara Lonkkāgaccha still has one yati but no $s \bar{a} d h u$ s. A notable feature of the yati traditions is that they do not have any female members.

30 The surprisingly high figure of more than 3,517 ascetics and a higher proportion of monks than nuns is reported in the $\mathrm{A}(\tilde{\mathrm{n}})$ cala Gaccha Pattāvalī for the $\mathrm{A}(\tilde{\mathrm{n}})$ cala Gaccha in the year 1180. It is said that Ācārya Āryarakșita Süri (1080-1180) initiated '2100 sâdhus and 1130 sâdhvîs, the âcârya-padam to 12 sâdhus, the upâdhyâya-padam to 20 , the paṇịita-padam to 70, the mahattarâ-padam to 103 sâdhvîs (Samayaśrî and others), the pravartinî-padam to 82 sâdhvîs, the total number of sâdhus and sâdhvîs being 3517' (Klatt 1894: 175). If the figures are true, then a huge number of Jain mendicants must have existed during the heydays of Jainism in the medieval period.

31 The equally centralised Rāmacandrasūri Samudāya of the Tapā Gaccha is the largest order. Balbir 2003: 48f. provides much information on the doctrinal foundation of the $\mathrm{A}(\tilde{\mathrm{n}}) \mathrm{cala}$ Gaccha, but not on initiation procedures.

32 According to Ācārya Jay Sundar Sūri of the Bhuvanabhānu Samudāya, the last sanghāacārya of the Vijaya Śākhā was Ācārya Vijay Prabhā, who commanded. c.200-300 ascetics. After him the number of samvegi $s \bar{a} d h u$ s decreased to 20-25 under Buterāy in the early nineteenth century (plus 10-15 in the Sāgara Sākhāa and 40-50 in the Vimala Gaccha), while the Tapa Gaccha yati orders had more than 1,500 members. Personal communication, Mumbaī 23 October, 2005.

33 Cf. Kañcansāgarsūri et al. 1977: 355-61.

34 Desāī 1983 I: 106ff., M. Śāh 1987. The precise origins of the trust are not known, but Sāntidās Jhaverī was instrumental in institutionalising this influential organisation.

35 Probably only the samvegi $s \bar{a} d h u$ tradition was interrupted.

36 Kañcansāgarsūri et al. 1977.

37 See Paul Dundas' forthcoming book.

38 Only the Kharatara Gaccha and the $\mathrm{A}(\tilde{\mathrm{n}})$ cala Gaccha still have some yatis.

39 'In his biography of Nemīsurri, one of the great reformist ācāryas of the early twentieth century, Sílcandravijay 1973: 6 has estimated the number of samvegī sādhus 


\section{PETER FLÜGEL}

in the period $1845-1865$ to be no more than 25 to 30 . While it is not clear if he means only within the Tapā Gacch, or in all the Mūrtipūjak gacchas, the number is still very small. He further comments on the low level of scholarly knowledge among these $s \bar{a} d h u$ s. Thus, the position of the Śvetāmbar samvegī sā $d h u$ in the early nineteenth century was not all that different from the position of the full-fledged muni, or nirvān $s v \bar{a} m \bar{\imath}$, among the South Indian Digambaras (see Carrithers...)' (Cort 1989: 99, n. 14). Unfortunately, the only information we have on the numbers of yatis in the nineteenth century are a number of kșetrādeśapattakas and sporadic evidence in the reports of British colonial officials. A cāturmāsa list of 1867 issued by the successor of Ācārya Vijay Devendra Sūri, Ācārya Vijay Dharanendra Sūri, for instance, lists 212 monks (figures for nuns are not given) organised into 74 groups of 2 and 14 groups of 4 (Sandesara 1974: 229-233). For the year 1891, Singh 1894: 82 cites the number of 834 'jatis' in Marwar (Jodhpura) alone, but gives no figures for the samvegīs, who 'owe their origin to one Anand Bimal Suri' (ibid.: 95). The Jain mendicants in Mārvār were classified as 'devotees' of the 'priests' (yatis, brāhmaṇs, etc.) and all counted under the label 'Samegi, Dhundia etc.' (ibid.: 85). Their total figure of 2,314 comprises 725 male and 1,589 female mendicants.

40 The Jain Śvetāmbara Directory published in 1916 by the reformist Jain Association of India lists some 228 monks, divided into 79 groups, and 203 nuns, divided into 40 groups, apparently belonging to reformed segments of the Tapā Gaccha, including the groups of the ācāryas Vijay Kamal Sūri, Vijay Nemī Sūri and Buddhi Sāgar Sūri which were mainly active in Kacch and Mạrvāṛ (Jain Śvetāmbara Conference 1916: 18-22).

41 See Cort 1999.

42 In 2002, the total number had increased to 7,541 mendicants, 1,585 munis and 5,947 $s \bar{a} d h v \bar{\imath} \mathrm{s}$. The Tapā Gaccha had 6,696 mendicants, 1,445 sādhus and 5,242 sādhvīs (cf. ibid.: 70, 305).

43 Jaini 1991: 26 explains the attractiveness of the Tapā Gaccha for women with the 'spiritual equality' offered to Śvetāmbara $s \bar{a} d h v \bar{\imath}$ s. However, Mūrtipūjaka $s \bar{a} d h v \bar{\imath}$ s are still not allowed to read certain àgama-texts nor to deliver public sermons, a fact which Shāntā 1985: 315, 321f., n. 5, 456 explains by pointing at the high number of $\bar{a} c \bar{a} r y a \mathrm{~s}$, which limits speaking opportunities.

44 'The samudāy is not as formal a grouping as the gacch. Mendicants in one samudāy will, for a variety of reasons, sometimes travel with mendicants of another samudāy. But mendicants do not travel with mendicants of another gacch, as that would involve changing some of the details of their daily practices' (Cort 1991: 663). In his later publications, Cort 1999: 44, 2001: 46 supplies enough material for the conjecture that many samudāyas have a distinct doctrinal and organisational identity with separate pañcāingas, rituals and lay support.

45 Shāntā 1985: 329.

46 The use of the sign '-' in the columns indicates cases of separation (cf. Tristuti Gaccha).

47 The names of all ācāryas of the Vijaya Śākhā are preceded by the title 'Vijaya'. Some gacchādhipatis are not ācāryas (sūri).

48 After his death, Prem Sūri's line split into two samudāyas, led by Rām Candra Sūri and Bhuvan Bhānu Sūri respectively. Following Rām Candra Sūri's (1896-1991) death, this samudāya was named after him by his successor Mahoday Sūri (died 2002), who was in turn succeeded by Ācārya Hem Bhūṣan Sūri (B. U. Jain 1996: 165-177). Rām Candra Sūri was one of the most influential and orthodox ācāryas of the Vijaya Śākhā. He nearly became the leader (śāsanasamrāta or adhipati) of the entire Tapā Gaccha. Cort 1989: 103, n. 18 quotes demographic data which show that the Dān-Prem Samudāya has grown from 36 sādhus in 1944 to 219 sādhus in 1975 


\section{DEMOGRAPHIC TRENDS IN JAINA MONASTICISM}

(Cort had no information on the numbers of $s \bar{a} d h v \bar{\imath} \mathrm{s}$ ). By 1999, this tradition had split into four sections, including Śānti Candra Sūri's group, and Vibuddha Prabhā Sūri's group. However, after 1996 the Amṛtasūri Samudāya, lead by Jinendra Sūri, was reintegrated into the Rāmacandrasūri Samudāya, which had in all 905 members in 1999, $290 s \bar{a} d h u$ s and $615 s \bar{a} d h v \bar{\imath} \mathrm{s}$, and 1,138 members in 2002, 310 munis and 828 sādhvīs (B. U. Jain 1999: 197, 2002: 169). Important particularities, in addition to the be tithi doctrine, are the performance of guru pūja in the manner of the astaprakāri pi $\bar{u} j \bar{a}$ to the body of the ācārya Rām Candra Sūri and his statues, and the permission for lay followers to mount Śatruñjāya Hill even during cāturmāsa (personal communication).

49 This group separated in 1998 from the Rāmacandrasūri Samudāya. It operates mainly in Rājasthān. In 1999 it had 45 mendicants, 23 sādhus and 22 sādhvīs (B. U. Jain 1999: 325f.).

50 This samudāya also derives from Prem Sūri, but was renamed after Bhuvan Bhānu Sūri (1911-1993) who broke with Rām Candra Sūri in 1986 after a dispute on calendrical issues (ek tithi-be tithi). See Cort 1999, B. U. Jain 1996: 179-87. Originally, the group was active in Hālār, but its main sphere of activity is now Gujarāt and Mahārāștra. In 1999 it had 560 members, 285 sādhus and 275 sādhvīs (B. U. Jain 1999: 230), in 2002712 members, $361 s \bar{a} d h u$ s and $351 s \bar{a} d h v \bar{\imath} \mathrm{s}$ (B. U. Jain 2002: 186). It is one of the few contemporary Jain orders which has more monks than nuns, because Ācārya Prem Sūri objected to the initiation of sā $d h v \bar{\imath} \mathrm{s}$, since their presence would inevitably cause the development of relationships between monks and nuns. One of Prem Sūri's disciples, Ācārya Jaśodev Sūri, successfully criticised this rule, by pointing to the unnecessary problems it creates when entire families want to renounce. Prem Sūri allowed him to start an order of nuns within his tradition, on the condition that he and his successors would be responsible for the supervision of the nuns, of which the main line of gacchädhipatis should remain aloof. After the death of Jaśodev Sūri, his successor Rajendra Sūri is now responsible for the $s \bar{a} d h v \bar{\imath}$ section.

51 This group separated itself in 1995 under Prem Sūri from the tradition of Rām Candra Sūri (whose guru was Prem Sūri). In 1999, it was nominally reincorporated into the Rāmacandrasūri Sampradāya, but still maintains a separate existence. It is mainly active in Hālār, near Jāmnagar. In 2002 it had 26 mendicants, 4 sādhus and 22 sādhvīs (B. U. Jain 2002: 170, cf. 273).

52 Nìti Sūri was a pupil of Buddhi Vijay and the teacher of Bhakti Sūri and Siddhi Sūri (Ratna Prabha Vijay 5, 2 1948-1950: 217f.). In 1999, this group had 465 mendicants, $50 s \bar{a} d h u$ s and 415 sādhvīs (B. U. Jain 1999: 254), in 2002, 426 mendicants, 40 sādhus and 386 sādhvīs (B. U. Jain 2002: 211).

53 In 1999, this group had 245 mendicants, 49 sādhus and 196 sādhvīs (B. U. Jain 1999: 295), the figures for $2002-128$ mendicants, $46 s \bar{a} d h u$ s and 82 sādhvīs - are incomplete (B. U. Jain 2002: 250).

54 Figures for the period between 1987 and 1996 are incomplete. In 1999, this group had 384 mendicants, 27 sädhus and 357 sādhvīs (B. U. Jain 1999: 271), in 2002, 311 mendicants, $31 s \bar{a} d h u$ s and $280 s \bar{a} d h v \bar{\imath}$ s (B. U. Jain 2002: 227). Today, Ācārya Vijay Arihant Sūri is the head of the order. Apparently, 150 sādhvis joined the Rāmacandrasūri Sampradāya (ibid.: 231).

55 Siddhi Sūri (1895-1959) was succeeded by Megh Śrī. One of his pupils was Bhuvan Vijay, the father and dīkșā guru of the influential scholar Muni Jambū Vijay. In 1999, it had 250 mendicants, $30 s \bar{a} d h u$ s and $220 s \bar{a} d h v \bar{\imath}$ s (B. U. Jain 1999: 289), in 2002, 260 mendicants, 29 sādhus and $231 s \bar{a} d h v \bar{\imath}$ s (B. U. Jain 2002: 240). The present gacchādhipati Rām Sūri has been selected, because he is the ācārya with the highest monastic age (ibid.: 246).

56 Dev Sūri's (1911-2002) predecessor was Merū Prabhā Sūri. The present head of the order is Ācārya Suśîl Sūri. In 1999 this group had 543 mendicants, 138 sādhus and 
405 sādhvīs (ibid.: 242), and in 2002, 567 mendicants, 146 sädhus and $421 s \bar{a} d h v \bar{\imath} \mathrm{s}$ (B. U. Jain 1999: 230). It is mainly active in Gujarāt and Rājasthān, and has produced many scholarly monks.

57 Vijay Vallabh Sūri (1870-1954) was one of the most influential reformers of the Tapā Gaccha in the twentieth century and an important promotor of modern education and social reform. He was initiated in 1886 by Vijay Ānand Sūri (Ātmā Rām). The ascetics of this tradition wear yellow garments, originally to distinguish themselves from the yatis who were clad in white. They permit nuns to give public lectures, and use microphones and in big cities flush toilets (in other samudāyas the excretions of the mendicants are collected and then flushed away by the laity). They share food with the mendicants of the Keśarasūri and Dharmasūri Samudāyas, who descend from the same lineage. In 1999, this group had 274 mendicants, 54 sädhus and 220 $s \bar{a} d h v \bar{\imath}$ s (B. U. Jain 1999: 277), and in 2002, 295 mendicants, 60 sādhus and 235 $s \bar{a} d h v \bar{i}$ s (B. U. Jain 2002: 232). After the death of Vijay Indradinn Sūri (1923-2002), who originated from a tribal group in Gujarāt, Ācārya Vijay Ratnākar Sūri became the head of the order.

58 In 1999, it had 259 mendicants, 57 sādhus and $202 s \bar{a} d h v \bar{\imath}$ s (B. U. Jain 1999: 284), in 2002, 250 mendicants, 55 sādhus and 195 sādhvīs (B. U. Jain 2002: 235). Jin Bhadra Sūri died in 1999. His predecessor was Kīrti Candra Sūri, his successor as gacchādhipati is Aśok Ratna Sūri (B. U. Jain 1999: 288f.).

59 Mohan Lāl was a pupil of Khānti Viyay, who was a disciple of Buddhi Vijay. He was particularly active in Bombay. In 1999, this group had 44 mendicants, 22 sădhus and $22 s \bar{a} d h v \bar{\imath} \mathrm{s}$ (B. U. Jain 1999: 323), in 2002, 57 mendicants, $26 s \bar{a} d h u$ s and $31 s \bar{a} d h v \bar{\imath} \mathrm{s}$ (B. U. Jain 2002: 272).

60 Vijay Dharma Sūri (1868-1922) was an influential moderniser. He was initiated in 1887 by Vrddhi Candra Vijay (died 1893), a pupil of Buddhi Vijay, and was succeeded by Vijay Indra Sūri (born 1881). In 1999, this group had 236 mendicants, 33 sādhus and 203 sādhvīs (B. U. Jain 1999: 302), in 2002, 229 mendicants, 33 sädhus and 196 $s \bar{a} d h v \bar{\imath}$ S (B. U. Jain 2002: 251).

61 Hem Prabhā Sūri's predecessor was Svayam Prabhā Sūri. The figures for 1987-1996 are based partly on estimates. In 1999, this group had 188 mendicants, 14 sädhus and $174 s \bar{a} d h v \bar{\imath}$ s (B. U. Jain 1999: 309), in 2002, 217 mendicants, 22 sādhus and $195 s \bar{a} d-$ hvīs (B. U. Jain 2002: 258).

62 Kanak Sūri was the teacher of Catur Vijay, the teacher of Punya Vijay (1895-1971), who inspired the creation of the L. D. Institute in Ahmedabad in 1957. In 1999, this group had 451 mendicants, 29 sādhus and $422 s \bar{a} d h v \bar{\imath}$ s (B. U. Jain 1999: 262), in 2002, 533 mendicants, $35 s \bar{a} d h u$ s and 498 sādhvīs (B. U. Jain 2002: 217). After the death of Kalāpūrn Sūri in 2002, Ācārya Vijay Kalā Prabhā Sūri became head of the order (gacchädhipati), which is also called Kaccha-Bāgara Samudāya, because of the regional base of Kanaka Sūri (ibid.: 226).

63 Ratnākar's predecessor was Lakṣmī Sūri. This samudāya is predominantly active in Mevār. In 1999, this group had 148 mendicants, 20 sādhus and 128 sādhvīs (B. U. Jain 1999: 313), in 2002, 153 mendicants, 22 sādhus and $131 s \bar{a} d h v \bar{\imath} \mathrm{s}$ (B. U. Jain 2002: 261).

64 Śānti Candra Sūri was a pupil of Vijay Ānand Sūri (Ātmā Rām). In 1999, this group had approximately 75 mendicants, $25 s \bar{a} d h u s$ and $50 s \bar{a} d h v \bar{s}$ (B. U. Jain 1999: 322), and in 2002, 165 mendicants, 19 sādhus and 146 sādhvīs (B. U. Jain 2002: 270). In 2002, Bhuvan Śekhar Sūri died and was succeeded by Ācārya Rājendra Sūri (ibid.: 271).

65 Both the present ācārya Som Sundar Sūri and Jin Candra Sūri were initiated by Bhuvan Sekhar Sūri. In 1999, this group reported the figure of 80 mendicants, 8 sād$h u$ s and $72 s \bar{a} d h v \bar{s}$ (B. U. Jain 1999: 320), in 2002, 151 mendicants, 19 sādhus and $132 s \bar{a} d h v \bar{\imath} \mathrm{s}$ (B. U. Jain 2002: 268), but the figures are incomplete. 
66 This group was started by Ānand Sāgar Sūri, a bitter opponent of Rām Candra Sūri, the leading monk of the Vijaya Śākhā in the twentieth century (cf. Cort 1999: 43): 'Rāmcandra Sūri (1895-1991) has argued that the scriptures should not be published at all, a view which found many partisans, while the other party followed the view that of Sāgarānanda Sūri (1875-1950), celebrated as the "uplifter of the scriptural tradition" (ägamoddhāraka), who advocated the publication of the scriptures but along with the old niryukti and vrtti commentaries' (Dundas 1996: 90, cf. Banks 1992: 110). The group experienced frequent changes of leadership in the 1980s. In 1986, the leader was Devendra Sāgar, 1987 Cidānand Sāgar, 1990 Darśan Sāgar, who was succeeded by Sūryoday Sāgar, and Aśok Sāgar in 2004-2005. The former sādhu Citra Bhānu (Candra Prabhā Sāgar), who continues to inspire diaspora Jains in the US and the UK, was a member of this lineage from 1942 to 1970. In 1999, this group had 740 members, 150 sādhus and 590 sādhvīs (B. U. Jain 1999: 215), in 2002, 956 members, 136 sādhus and 820 sādhvīs (B. U. Jain 2002: 171). Its main agenda is currently the defence of the scientific accuracy of the canonical Jaina cosmography.

67 Buddhi Sāgar Sūri (1874-1925), a disciple of Ravi Sāgar and one of only four saṃvegī sādhu ācāryas in 1913 (Cort 1997: 125), popularised the worship of the protector god Ghaṇtākarṇa amongst Gujarātī Jains, particularly in Mahudi near Vījāpur (Cort 1989: 406-407, 428-433, 2001: 91, 164-168). He was succeeded by Monogam Sāgar (?), Rudhi Sāgar, and Subodh Sāgar Sūri, who inspired the construction of the tirrthas Vījāpur and Mahesānāa, where the tīrthañkara Sìmandhara Svāmīi is venerated. Ācārya Padma Sāgar Sūri (born 1934), who inspired the construction of the Jain centre at Kobā near Ahmedabad, also belongs to this order. In 1999, this samudāya had 135 mendicants, 45 sādhus and 90 sādhvīs (B. U. Jain 1999: 316); for 2002 the figures are incomplete: 115 mendicants, 45 sādhus and $70 s \bar{a} d h v \bar{i}$ s (B. U. Jain 2002: 264).

68 Cidānand Sūri's predecessor was Ravi Vimal Sūri. He is now succeeded by Pradyumna Vimal Sūri. Figures are based on estimates. In 1999, it had about 51 mendicants, $6 s \bar{a} d h u$ s and $45 s \bar{a} d h v \bar{\imath}$ s (B. U. Jain 1999: 360), in 2002 approximately 49 mendicants, 4 sādhus and $45 s \bar{a} d h v \bar{\imath}$ s (B. U. Jain 2002: 304).

69 This sampradāya, which is also called Vidhi Pakșa, is mainly active in Kacch, Hālār and Mumbaī (Jain 1996: 274). In 1999, it had 250 members, 29 sādhus and 221 $s \bar{a} d h v \bar{\imath} \mathrm{s}$ (B. U. Jain 1999: 327), in 2002249 members, 29 sādhus and $220 s \bar{a} d h v \bar{v} \mathrm{~s}$ (B. U. Jain 2002: 274). For its history see Śivprasād 2001, Balbir 2003.

70 Jin Mahoday Sāgar Sūri’s predecessor was Jin Uday Sāgar (died 1996). The current gacchādhipati is Upādhyāya Kailāś Sāgar. This sampradāya is mainly active in Rājasthān, Mahārāșțra, Gujarāt, M.P., Dillī and Mumbaī. In 1999, it had 229 mendicants, 20 sādhus and 209 sādhvīs (B. U. Jain 1999: 340), in 2002258 mendicants, 28 $s \bar{a} d h u$ s and $230 s \bar{a} d h v \bar{\imath}$ (B. U. Jain 2002: 286).

71 Figures are incomplete. In 1999, this group had 118 mendicants, 28 sādhus and 90 $s \bar{a} d h v \bar{i} s$ (B. U. Jain 1999: 340), in 2002, 127 mendicants, 27 sādhus and 100 sādhvīs (B. U. Jain 2002: 293). The a āârya position is the only administrative post of this group (B. U. Jain 1999: 252, n.4). In the year 2000, a group of three sādhus led by Muni Jay Ānand split off and founded a fourth Tristuti tradition (B. U. Jain 2002: 293). The most famous monk of the Tristuti Gaccha was Rājendra Sūri (1827-1906), who is renown as the composer of the Abhidhānarājendra Kośa.

72 In 1999, this group comprised approximately 70 mendicants, 19 sädhus and 51 sādhvīs (B. U. Jain 1999: 353); in 2002, 73 mendicants, 22 sādhus and 51 sādhvīs (B. U. Jain 2002: 297).

73 Praśam Candra's predecessor was Labdhi Sūri (1884-1961). In 1999 and 2002, this group consisted of 2 sādhus only (B. U. Jain 1999: 361, 2002: 299).

74 Because of a dispute on proper ascetic conduct, this order split from the Tapā Gaccha in 1515 under Sādhu Ratna Sūri (Ratna Prabha Vijay 5, 2 1948-1950: 134). Although this group is sometimes considered to be part of the Tapā Gaccha, its sādhus do not use 
'vijaya' or 'sāgara' as a suffix or prefix. The group does not have administrative posts and is the only order that is led by two monks: Muni Bhuvan Candra is currently responsible for the region of Kacch and Saurāstra, and Muni Vijay Candra for the region of Mumbaī. Bhuvan Candra's predecessor was Muni Rām Candra. In 1999, this group had 74 mendicants, 9 sādhus and $64 s \bar{a} d h v \bar{\imath}$ s, though numbers are incomplete (B. U. Jain 1999: 356), in 2002, 68 mendicants, 9 sādhus and 59 sādhvīs (B. U. Jain 2002: 301).

75 Figures are incomplete. B. U. Jain 1999: 362 estimates a total of $28 s \bar{a} d h u$ s for the year 1999, and 16 for the year 2002 (B. U. Jain 2002: 305).

76 Cort's observations are inversely mirrored by R. K. Jain's 1999: 32 distinction between the charismatic 'individualistic, prophet-derived and sect-like character of the Digambara religious field as contrasted with the group-bound, "priest"-derived and church-like ambience of the Shvetambara religious field'; a distinction which deliberately ignores the institutions of the bhattāraka traditions.

77 Cort 2001: 46 observed that subtle liturgical differences do not exist 'between samudāys'. However, according to Muni Mukti Vallab Vijay of the Bhuvanabhānu Samudāya, four different lists of maryādās exist within the Tapā Gaccha. A leading monk of the Ramacandrasūri Samudayya mentioned the figure of 64 differences in the rules and regulations of the samudāyas. A number of monks and nuns of other samudāyas confirmed these statements (personal communications, December 2004-January 2005). But more research is necessary to map out the details.

78 Only if their samudāyas derive from the same lineage food is sometimes shared; for instance between the members of the Vallabhasūri, the Keśarasūri and the Dharmasūri Samudāyas.

79 Personal communication of monks and nuns of the Vallabhasūri Samudāya and of the Rāmacandrasūri Samudāya in January 2005. In his will, Rām Candra Sūri determined Mahodaya Sūri as his successor. But according to A. Luithle (personal communication, July 2005) the present gacchādhipati Hem Bhūṣan Sūri was elected in an assembly of àcāryas in 2003 after one year of dispute.

80 Cf. Jacobi 1915: 270, Cort 1991: 669, n. 19.

81 As evidence, the cases of the centralised orders of the A(ñ)cala Gaccha, the Ramacandrasūri Samudāya, and the Śvetāmbara Terā Panth may be cited, all of which have a large number of members.

82 The contrast between the principles of pupillary descent and group organisation in Jain monastic traditions has been analysed in Flügel 2003b: 182-193.

83 Personal communication, Ācārya Jay Sundar Sūri, Mumbaī 23 October 2003.

84 The term sthänakavās $\bar{\imath}$ in its present meaning became only current in the context of the early twentieth century unification movement of the traditions of the pañcmuni.

85 The dates given in the available sources are not matching up. See Flügel 2000: 46-48, in press.

86 See Flügel 2000: 61-68 on the grades of the sāmāyika vow.

87 Flügel 1995-1996, 2000, 2003a, 2003b, in press.

88 Jaini 1979: 246f., n. 8 quotes the figure of 847 mendicants for the year 1977. Goonasekere 1986: 27 speaks of about c.900 for the year 1983. Cort 1989: 491, 96 calculates altogether 553 ascetics - probably for the year 1986. Shāntā 1985: 332, 341, 489 cites Terā Panth sources for the much higher figure of 1,757 ascetics for the year 1981, which broadly corresponds to Sangave's 1980: 323f. plausible figure of 1,900 Sthānakavāsī mendicants in the year 1946.

89 B. U. Jain 2002: $65 f$.

90 This is seen as a potential cause of conflict. Personal communication, Ratan Jain, Delhi 16 October 2004.

91 This is in accordance with the scriptures. See Thanna 164b, Vav 10.15-17 and the Nisīha Bhāsa. On the issue of child initiation see also Balbir 2001. 
92 See Flügel forthcoming.

93 The resolution was taken on the 5-6 December 1932. See Jauharī 1946: 197.

94 Another source informs us that, at the time of Lonkā's death, the Lonkā Gaccha had 400 disciples and 800,000 lay followers (Prakāścandra 1998: 32).

95 Manohar Dās was a disciple of Dharma Dās. The two Amarmuni traditions continue his line today.

96 The following figures were given by Manilāl (1934) for selected smaller traditions in 1933: Khambhāt Sampradāya (15 mendicants: 6 sādhus and 9 sādhvīs), Cauthamala (Raghunātha Dharmadāsa) Sampradāya (18 mendicants: 3 sādhus and 15 sādhvīs), Ratnavamśa (Dharmadāsa Sampradāya) (47 mendicants: 9 sādhus and 38 sādhvīs), Nānā Prthvīrāja (Mevāra Dharmadāsa Sampradāya) (43 mendicants: 8 sādhus and 35 sādhvīs), Kaccha Āth Koți Moțā Pakșa (53 mendicants: 22 sādhus and 31 sādhvīs), Kaccha Āth Koṭi Nānā Pakṣa (39 mendicants: 14 sādhus and 25 sādhvīs), Līmbadī Gopāla Sampradāya (26 mendicants: 7 sādhus and 19 sādhvīs), Gonḍala Nānā Pakșa (no sādhus and 'some' sādhvīs), Barvādā Sampradāya (24 mendicants: 4 sādhus and 20 sādhvīs).

97 The latest findings have been summarised by Degenne and Forsé (1999: 21): 'Acquaintances form the largest, a virtual network that includes everyone the respondent has ever met. The average for this outermost circle is about 5,000 people. The circle of immediate contacts is far smaller. The average respondent has only 100-200 people he can contact to link himself up to a target stranger. She has regular talks with fewer than twenty people per week, subject to variation with age, sex, education and other sociodemographic criteria. Again, real confidants average only three'.

98 It is regarded as a sign of the laxity though if Jain mendicants deliberately maintain contacts, because this contradicts their vow to renounce the world.

99 For a comparable study in the context of Christian monasticism see Sampson 1969. I have collected data for an analysis of a Jain monastic network in the year 2001. See Flügel forthcoming.

100 This argument is outlined in Flügel 2003b: 183.

101 Nair 1970: 6-7 quotes Muni Dhana Rājā's data for 1955 and 1969. Balbir 1983: 40f gives figures for 1975 and 1981. Shāntā 1985: 332, 341, 489 cites a Terā Panth census by Nāhatā for 1982. The total number of ascetics in 1983 can be found in Goonasekere 1986: 27, who reproduced historical data from 'a Jain Śvetāmbara Mahāsabhā Publication' (ibid.: 88f.). His tables do not contain information on the composition of the monastic community after 1944, which can be extracted from the volumes edited by Navratnamal 1981ff. and the tables of Balbir 1983: 41, B. U. Jain 1987: 77, 1990: 62-63 and in the annual almanacs of the Terā Panth (e.g. Navratnamal 1991: 28).

102 See Flügel 2003a.

103 Cf. B. U. Jain 1999: 193. New intermediary categories of female novices, or samanera, are also characteristic for the reformist 'protestant Buddhism'. See Bloss 1987: 13, Kawanami 1990: 20.

104 The change affected the sādhvīs first. Under Ācārya Rāy Cand (1821-1851) and Ācārya Jītmal (1851-1881) only $58.44 \%$ and $57.1 \%$ of all newly initiated $s \bar{a} d h u$ s were Osvāls, but already $73.8 \%$ and $89.3 \%$ of all new sādhvīs. Under Kālū Rām, $89.7 \%$ of newly initiated $s \bar{a} d h u$ s and $95.3 \%$ of $s \bar{a} d h v \bar{\imath}$ s were Osvāls (Navratnamal 1981 II: 311, 322, III: 273, 291, X: 309, 325). This pattern still prevails. In 1985, $96.98 \%$ of the Terā Panth sādhus and $94.46 \%$ of the sādhvīs were Osvāls (Navratnamal XII 1985: 522f.).

105 A percentage of 58.6 of Ācārya Jītmal's ascetics came from Mārvār and Mevār and only $24.9 \%$ from the Thalī region. By contrast, only $29.7 \%$ of Ācărya Kālū Rām's ascetics were recruited in Mārvār and Mevār, but $60.97 \%$ in Thalī. This pattern was perpetuated under Ācārya Tulsī. In 1985, 23.5\% of his mendicants came from Mārvār and Mevār and $63.3 \%$ from Thalī (sādhus: $58.62 \%$, sāâdhvīs: $65.35 \%$ ) 
(cf. Navratnamal 1981 II: 311, 322, III: 273, 291, VI: 486, 495, VIII: 348, 356, X: 309, 325, 1985 XII: 522).

106 The average number of initiated ascetics is one of the determinants of the status of an $\bar{a} c \bar{a} r y a$. On average, Bhikșu initiated 1.13 sādhus and 1.3 sādhvīs per year, Kālū Rām 5.63 sādhus and 9.44 sädhvīs, and Tulsī 4.84 sādhus and 11.13 sādhvīs between 1936 and 1981.

107 For a statistical analysis of the demographic structure of the Terā Panth order and the motives of renunciation in the year 2001 see Flügel forthcoming.

108 While his predecessors initiated on average $c .20 \%$ of minors, Kālū Rām initiated 45.8\% under age sādhus and 41.5\% under age sādhvīs (Navratnamal 1981: 309, 325). The Terā Panth has not yet followed the example of the Sthānakavāsī Śramana Sangha, which has officially raised the minimum age for initiation for both girls and boys from eight to fourteen.

109 Cf. Balbir 1983: 42, 2001.

110 On the Tārana Svāmī Panth see Cort (in this volume). The Totā Panth and the Gumāna Panth, an eighteenth century splinter group of the Terā Panth, have not yet been studied systematically. For an overview see Sangave 1980: 51-54.

111 M. U. K. Jain 1975: 94f.

112 The following historical reconstruction is therefore necessary.

113 P. Śāstrī 1985b: 537.

114 No source is given.

115 'Inhī gach meṁ nīkasau, nūtan terahpanth / solah sai terāsie, so sab jab jānant //631//' (Bakhatrām, in Premī 1912/n.d.: 22).

116 Cort 2002: 67 lists a reference to Megha Vijaya, who located the origin of the Adhyātma movement in 1623, in an appendix.

117 No original sources of the tradition itself on its origins have been found so far. I follow John Cort's 2002: 52f., 67-69 summary here.

118 Narendra Kīrti of Amer was bhatțāraka between 1634 and 1665 (Premī, cited by Cort 2002: 52).

119 P. Śāstrī 1985b: 536, cf. p. 538 found the expression 'terā - bhagavan āp kā panth' not only in Joghrām (Joghrāj) Godīkā's work, but also in Jñān Cand's work Śāvakācāra and in the Jaypur Pandịt Pannālāl's Terā Panth Khanḍan, where also thirteen practices are listed which the tradition rejected - opposing the use of fruits in $p \bar{u} j \bar{a}$, the worship of Padmāvatī and other gods and goddesses, etc. (ibid.: 539). For more references see P. Śāstrī 1992: 146-149.

120 Like the Śvetāmbara Terā Panthīs, the Digambara Terā Panth pandits exploit the ambiguity of the word terā panth. The two words terā and terah are homonyms: tera means 'your' and terah means 'thirteen'. However, it seems the Śvetāmbara Terā Panthīs prefer to interpret 'your' (terā) more in the sense of 'the people' rather than 'God'. Cf. Budhmal 1995: 69-76, Flügel 1994-1995: 123, n. 12, cf. p. 122, n. 9. It is likely that this wordplay is a religio-poetic topos that can be found in other traditions as well.

$121 \mathrm{He}$ refers to a newly found inscription from $950 \mathrm{CE}$ which identifies the Balātkāra Gaña with the Sarasvatī Gaccha and the Mūla Sangha: 'vi. samvvat 1007 māsottamamāse phàlgunamāse śuklapakșe tithau caturthām budihavāre śrìmūlasañgha sarasvat̄̄gaccha balātkāragaṇa țhākurasī dās pratișthaṃ' (in P. Śāstrī 1985b: 535), and - because the word śuddamnnaya is used in different contexts both for the Terā Panth and the Balātkāra Gaṇa - concludes elsewhere that they are one: 'terāpanth śuddhāmnāya tathā mūlasan்gha kundakundāmnāya balātkāragaña sarasvatīgaccha ye donom ek haim’' (P. Śāstrī 1992: 146).

122 On the presumed special relationship with the Parvār caste see particularly P. Śāstrī 1992: 114-149. 
123 'kahe jodh aho jin! terāpanth terā hai' (Joghrām Godīkā, in P. Śāstrī 1985b: 538). See also Paṇdit Pannālāl cited ibid., and P. Śāstrī 1985b: 536: 'terā - bhagavan āp kā panth'.

124 'bìsapanth arthāt vișampanth - terhāpanth jinmat mem mānya nahīm' (Jaina Nibandha Ratnāvalī, in P. Śāstrī 1985b: 538). The word was apparently coined by Jinendra in his Jñānānand Śāavakācāra which is cited by P. Śāstrī with approval (ibid.: 244).

125 Like the Terā Panthīs, the Tāraṇa Panthīs also venerate 'true' ascetics. See Tāraṇa Taraña Svāmī 1933, P. Sāstrī 1985c, and J. E. Cort (in this volume).

126 For the two debates between 20 August 1963 and 1 October 1963 in Jaypur on Kānjī Svāmī's theory of krama-baddha-paryāya, or sequence-bound-modification, see P. Śāstri 1967, 1985a, Jaini 1977, Bharill 1980, P. H. Śāstrī 1985. On the divisive disputes amongst the Digambaras after Kānjī Svāmī’s death, see R. K. Jain 1999: 101-117.

127 Jhaveri's 1914: 1418-1424 community census counted altogether 450, 584 Digambaras in 1914. For detailed numerical data on Jain castes from this census and the Śvetāmbara Directory of 1909 as well as the Colonial Indian Census see Sangave 1980: 119-121, 124-130.

128 Sangave 1980: 52. This estimate may be too high. According to P. S. Jaini (personal communication), the distinction was totally unknown in South India and is even now rejected by most.

129 Glasenapp 1925: 357, Sangave 1980: 52.

130 Cf. Cort 2002: 62. Earlier, the now extinct 'heterodox' Kāsthā Sangha was associated with the Agravāls in Rājasthān (K. C. Jain 1963: 72), and the Mūla Sangha, which was dominant in Western India between the fourteenth and the nineteenth century, primarily with the Khaṇdelvālas (and Parvārs) (ibid.: 73, 103). Both in South India and in North India, close relationships developed between Digambara gacchas and certain jātis or gotras. An important factor for the success of the Terā Panth amongst specific Digambara caste communities seems to have been the long term absence of the institution of the bhattäraka as a caste guru. Sangave 1980: 318 notes that in the 1950s 'the Hummaḍa Mevāḍā, Narasingapurā, Khaṇdelvāla, Saitavāla, Chaturtha, Pañchama, Bogāra, Upādhyāya, Vaiśya and Kshatriya castes have their separate Bhațāarakas while the Kathanerā, Buḍhelā, Agravāla, Golāpūrva, Jaisavāla, Nevi and Hummaḍa (from Mahārāshṭa) castes have no Bhațāaraka system at all. Besides in some castes like Paravāra, Bannore, Dhākaḍa and Bagheravāla the Bhatṭāraka system was prevalent formerly but now it is extinct'.

131 Glasenapp 1925: 357 reported that the contrast was so big that the followers of one 'sect' do not visit the temples of the other. However, through an unrepresentative survey amongst the Jain laity Sangave 1980: 299 found that 'among the persons who do not know about their divisions the Digambaras form a larger proportion than the Śvetāmbaras. Besides, it has been stated that there are no such divisions among the Digambaras at present'.

132 'The Bīspanth-Terāpanth division is not found in Karnataka, Tamil Nadu or southern Maharashtra' (Cort 2002: 70, n. 3).

133 R. K. Jain 1999: 89f., 101-117.

134 Cort 2002: 65 contrasts the lack of organisation of the Adhyātma movement with the 'organisational foundation' of the Terā Panth which is still influential. However, the organisational capacity of the local temple- and library trusts of the Terā Panthīs is insignificant compared to the old institutions of the bhattāraka traditions and in particular the (trans-) regionally organised Śvetāmbara sects.

135 Cf. Jhaveri 1914, Sangave 1980: $119 \mathrm{ff}$.

136 Cort 2002: 62.

137 See Deo 1956: 360ff. for a beginning. 


\section{PETER FLÜGEL}

138 We have seen that the Sthānakavāsīs also use the terms samudāya, sañgha and vamśa. According to Hoernle 1891: 342 āmnāya - 'succession' - is a synonym of kula, as is the term santāna. Anvaya - 'line' - can also be used as a synonym. Sangave 1980: 299 presents a less convincing picture of the organisational levels of the Digambara bhatțāraka traditions (saingha, gaṇa, gaccha, śăkhā) than Joharāpuraka 1958, whose book is still the most detailed study to date.

139 Joharāpurkara 1958: 19 noted that the writings of Kunda Kunda were 'certainly some cause of unease' between some of the late medieval bhattārakas of the Sena Gana. Allegedly, the 52 patța Bhatțāraka Vīr Sena (died 1938) had a great belief in Kunda Kunda's Samayasāra (ibid.: 35, n. 20). Many pattâvalīs of the bhatțāraka traditions present Kunda Kunda conventionally as their ancestor, for instance the Balātkāra Gaṇa (ibid.: 44, 71, n. 24).

140 Translated by Hoernle 1891: 350f., cf. Hoernle 1892: 59.

141 The third leader of the Nandi Sangha was apparently Kunda Kunda (Padma Nandin), who is cited as the ancestor of today's Sarasvati Gaccha of the Nandi line (anvaya) which identifies itself with the Balātkāra Gana of the Mūla Sangha and calls itself Kundakundānvaya (Hoernle 1891: 342, 350f.). The early dates for Kunda Kunda have been questioned by Dhaky 1991: 190, and the artificial link to Kunda Kunda by Dundas 2002: 122.

142 Epigraphia Carnatica 2, 77, 82, in Schubring 2000: $§ 30$, p. 63.

143 Schubring 2000: $\S 30$, p. 63 cites in this respect also Indra Nandin's sixteenth century work Nìtisāra and the nineteenth century pațtâvalīs translated by Hoernle 1891, 1892 .

144 See M. U. K. Jain 1975: 126-128 for the complex (putative) internal divisions of the Mūla Sañgha, whose history in South India has not been analysed.

145 Apart from the available inscriptions, praśastis and nineteenth century patțāvalīs, the two main sources on the history of the Digambara traditions are Deva Sena's Darśanasāra of 933 CE and the Śvetāmbara monk Guṇa Ratna's fifteenth century commentary to Haribhadra's Saddarśanasamuccaya. See the summaries by Glasenapp 1925: 355f., Schubring 2000: § 30, pp. 61-63, Varṇī 1997 I: 317 and Joharāpurkara 1958. A source cited by Delamaine 1827: 414 is the Buddhavilāsa.

146 Rāja Śekhara writes in his Saḍarśanasamuccaya 21-25 (c.1350): 'In the Kāsțhāsangha, the broom is ordained to be made of the yak's tail. In the Mūlasangha, the brush is made of peacock feathers. The broom has never been an issue in the Māthura Sangha. The Gopyas sweep with peacock feathers; their greeting is "dharma labha $\bar{a}$. The rest greet with "dharma vrddhi". The Gopyas declare release for women. The three Sanghas other than the Gopya declare that women cannot attain it. Neither the other three nor the Gopyas hold that an omniscient takes food; There is no release for one wearing a monk's garb, though he keep the vow well' (tr. by Folkert 1993: 363). Schubring 1964: 224 mentions that both the Yāpanīya and the Kāṣthā Sangha taught that women can reach salvation.

147 The view that the North Indian Kāsthā Sangha is 'heterodox' and the Mūla Sangha 'orthodox' is nowadays - after the disappearance of the Kāṣthā Sangha - expressed by Bīsa Panthīs and Terā Panthīs alike, which both claim descent from the Mūla Sañgha. See P. Śāstrī 1985b.

148 Premī 1912/n.d.: 4, M. U. K. Jain 1975: 130.

149 Schubring 2000: $\S 30$, p. 62.

150 Glasenapp 1925: 355.

151 Cf. Folkert 1993: 161, and Dundas 2002: 122.

152 The tradition was first mentioned in Deva Sena's Darśanasāra. There are two versions of its origins. According to the prevalent version it was founded in the year $753 \mathrm{CE}$ (? Vikram Samvat: $696 \mathrm{CE}$ ) in the village Nānded (Nandiyaḍ) in the region of modern Bombay by Ầārya Kumār Sena I of the Pañcastūpa Sangha (Kumārasena II lived around 955). Kumār Sena was a reformer who insisted on the observation of the 'sixth 
anuvrata', that is, no consumption of food and drink after dark, and on the performance of atonements in accordance with the Digambara Āgamas. A later and less popular (and convincing) version relates that Ācārya Loha I from the Nandi Sangha Balātkāra Gaṇa founded this tradition some 515 years after Mahāvīra. He converted 125,000 members of the Agravāla caste in Agrohā near Hisār, and used wooden $(k \bar{a} s t h \bar{a})$ images for the $p \bar{u} j \bar{a}$ ritual (this story contradicts other legends narrating the origins of this caste). The use of wooden images was strongly opposed by the older Digambara traditions, because it begins to rot after being bathed with milk and water during the traditional pañca kalyānaka püjās. The tradition was also known under the name Gopuccha Sangha, because the munis used whisks made of the hair of cow tails rather than peacock feathers (Glasenapp 1925: 356, Varnī 1998 I: 320f.). According to Joharāpurkara (1958: 211), the name Kāsțhā Sangha derives from the name of a village near Dillī. From the fourteenth century internal divisions are reported, and at the end of the seventeenth century four distinct branches, such as the older Māthura Gaccha, were established, with important seats in Ārā (Bihār), Hisār (Hariyānāā), Surat (Gujarāt), Gvāliyar (Madhya Pradeś) and Kārañjā (Mahārāștra) (ibid.: 6f., 210-212). The ācarryas and bhattēarakas of this tradition produced important literary works (cf. ibid.: 238-247). The Kāṣthā Sangha seems to have continued at least till the early nineteenth century and maybe into the twentieth century (cf. Glasenapp 1925: 356, Dundas 2002: 124 citing Col. Tod).

153 This is again mentioned in Surendra Kīrti's work Dānavīra Manikcandra of 1690. See M. U. K. Jain's (1975: 112-126) extensive description of the sub-divisions of this tradition.

154 According to both the Darśanasāra (Glasenapp 1925: 356), and the Subhāṣita Ratnasaṃdoha of Ācārya Amitagati II (993-1026 CE), the founder of the Māthura Gaccha was Muni Rām Sena, who became a ācarya in 896 CE; but he is not mentioned in the pattā $\bar{v} a l \bar{\imath}$ of the tradition (Varñi 1998: 321f.). He originally belonged to the Kāsthā Sangha and rejected both the use of peacock feather and cow hair whisks (picchi or piñchī). His tradition was therefore called Nispacchaka Sangha. He demanded from his disciples the explicit rejection of other gurus, and argued that salvation can only be reached through meditation on the true self ( $\bar{a} t m \bar{a}$ dhyanna) following the teaching of Kunda Kunda rather that Bhūtabali and Puspadanta's Șaṭkhaṇ̣āgama (Darśanapāhuḍa and Darśanasāra, ibid., Schubring 2000: § 30, p. 62). Until its demise sometime in the nineteenth or twentieth century, the main seats of this gaccha were in Hisār (Rājasthān), Gvāliyar, and Senāgiri (Madhya Pradeś) (Joharāpurkara 1958: 6f., 238-247). Its followers belonged mainly to the North Indian Agravāla caste (ibid.: 13).

155 Bāgada is a region near Chittor (M. U. K. Jain 1975: 118). Certain branches of the tradition may have predated the formation of the Kāsțhā Sangha (cf. ibid.: 118-120). It was also called Punnāta Gaccha, with reference to its place of origin in Karṇātaka, or Lājabāgaḍa Gaccha, with reference to its centre in Gujarāt. It is mentioned in inscriptions between the seventh century and fifteenth century and maintained important seats in Masāṛh (East India) and Kārañjā (Mahārāsțra) (Joharāpurkara 1958: 6f., 257-262). Its followers belonged mainly to the Baghervāl caste (ibid.: 13).

156 This tradition is mentioned only in two sources of the tenth and fifteenth century (Joharāpurkara 1958: 6f., 263). It apparently re-joined the Lāda-Bāgaḍa Gaccha (M. U. K. Jain 1975: 120).

157 This tradition (also: Vidyā Gaṇa and Rāmasena-Anvaya) was founded in the fifteenth century in the village Nandìtat - the modern Nāndeḍ/Mumbaī. It came to an end in the early ninteenth century. One of its main seats was Sojitrā in Gujarāt (Joharāpurkara 1958: 6f, 293-299). Its followers belonged mainly to the Hūmaḍa caste (ibid.: 13). The founder of this tradition appears to have been Ratna Kîrti (M. U. K. Jain 1975: 125). 
158 See in particular A. N. Upadhye 1933, 1970, 1974. For the subdivisions of the Yāpanīya tradition see M. U. K. Jain 1975: 136.

159 Premī 1912, n.d.: 4, Glasenapp 1925: 356.

160 Upadhye 1933: 225.

161 Schubring 2000: $\S 30$, p. 62 , n. 2 .

162 The details of the lineage histories in South India have yet to be investigated.

163 The tradition is first mentioned in the praśasti of the Uttarapurāna of Guna Bhadra's disciple Loka Sena $(898 \mathrm{CE})$ and in inscriptions of the ninth century and of the sixteenth century. It started with Candra Sena, Ärya Nandin and the famous scholastic Vīra Sena $(816 \mathrm{CE})$, the author of the Dhavalā Tî̀ā of the Satkhandāgama, and is famous for the many important Digambara philosophers such as Samanta Bhadra and Siddha Sena Divākara in its ranks. It had/has seats in Kārañjā (Akola, Berara) and Kolhāpura (still existing) in Mahāāștra. The tradition was occasionally called Sūrasthagaṇa and may have been popular in Saurāsțra during a certain period. The last bhatțāraka of this tradition was apparently Vīra Sena, a great believer in Kunda Kunda's Samayasāra, who died sometime between 1850 and 1938 (Joharāpurkar 1958: 6f., 26-38, cf. Upadhye 1948, M. U. K. Jain 1975: 84-88).

164 The tradition is first mentioned in inscriptions of the tenth century, most of them in Karnātaka. Its branches had seats in Ajmer, Bhānpur, Cittaur, Jaypur, Jehrahat, Nāgaur (Rājasthān), Ațer, Gvāliyar, Senāgiri (Mālvā), Ị̣̇ar, Surat (Gujarāt), Bhānapur, Jherahaț, Malakhẹ̣ and its sub-branches Kārañjā and Lātūr (Mahārāșțra). See Joharāpurkara 1958: 6f., 44-47, and the lineage diagram p. 209. The seats had special links to particular local castes, such as the Hūmad caste in Surat, the Lamecū caste in Ațer, the Parvār caste in Jerahat and the Khaṇdelvāla caste in Dillī and Jaypur (ibid.: 12). From the tenth (Śāstrī 1985b: 535) or the fourteenth century (Joharāpurkara 1958: 44) the tradition was known under the names Sarasvatī Gaccha, Vāgeśvāri Gaccha, Bhāratī Gaccha, Śāradā Gaccha. The original name seems to have been Balagāra Gana (ibid.: 44. cf. M. U. K. Jain 1975: 88ff.) and Nandi Sanggha (Hoernle 1891: 350, 1892: 73). In Kananda Balagāra (balegāra) means bangle-maker (a caste name) which was transformed into Skt. balatkāra or 'force' according to A. N. Upadhye. I am grateful to P. S. Jaini for this information.

165 Joharāpurkara 1958: 71-78. The tradition was established in the late fourteenth/early fifteenth century. The nineteenth and last patta of this branch was Devendra Kïrti, who died in 1916 (ibid.: 76f., n. 29). The Lātūra Sākhā split off this line in 1675 (ibid.: 77). Two samādhis have been built for bhatțārakas of this tradition (M. U. K. Jain 1975: 90, n. 80).

166 Joharāpurkara 1958: 86-90. See the picture of Bhattāaraka Viśāl Kīrti (died 1891) and of his successor who was also called Viśāl Kîrti and enthroned in 1914 (ibid.: 89f.). The seat in Lātūra is revered by the Saitavāla Jains (M. U. K. Jain 1975: 94, n. 92). According to Tuschen (1995: 23), it became defunct only recently.

167 This tradition started the bhattāaraka tradition by introducing the custom of wearing clothes in public. The main seats of this now defunct line, which was first closely connected with the Baghervāla caste and later with the 'Hūṃbad' and Brāhman castes were Surat etc. in Gujarāt, Ajmer, Dillī and Jaypur. After the death of Padma Nandin in 1493, the Uttara Sākhā branched out into the Ị̇ar, Surat and Dillī-Jaypur Śākhās (Joharāpurkara 1958: 93-96, cf. M. U. K. Jain 1975: 94-96).

168 This tradition was started by Sakal Kïrti. It possesses a famous library in Ị̇ar. See Joharāpurkara 1958: 153-158, cf. M. U. K. Jain 1975: 102-105.

169 In 1477 the Bhānapura Śākhā split off the İdara Śākhā. The last bhattāraka was apparently Devacandra (1730-1748). See Joharāpurkara 1958: 166-168. According to M. U. K. Jain 1975: 105 a splinter group of the tradition still prevailed in South India in 1975 (?). 
170 This branch, founded in 1436 by Devendra Kirti, was closely associated with the Hūmaḍa caste. In 1495 Tribhuvan Kīrti split off and founded the Jerahața Sākhā. See Joharāpurkar 1958: 194-201, 207, cf. M. U. K. Jain 1975: 107-111.

171 This branch, which became defunct early in the seventeenth century, was closely associated with the Parvār caste (Joharāpurkar 1958: 202-209, cf. Varn̄ī 1998 I: 320f.)

172 After 1514 the tradition split into three branches, two of which are the Nāgaura- and the Atera Sākhā. The last bhațtāraka of the Dillī-Jaypur line was apparently Candra Kīrti who either died or was installed in 1918 (Joharāpurkara 1958: 109-113). Cort (2002: 62) writes that the last bhattäraka, a Candra Kīrti, died in 1969 and was deliberately not replaced. The Dillī-Jaypur Sākhā was closely related to the Khandelvāla caste and established special links to the Kachavāhā kings of Amer, where the bhatțāraka seat was shifted in the sixteenth century (ibid.: 51, cf. Clémentin-Ojha, forthcoming).

173 In 1524, Ratna Kïrti was appointed as the first head. The last bhattāraka was apparently Devendra Kīrti in the mid-twentieth century (Joharāpurkara 1958: 121-125). Many bhaț̣ārakas belonged to the Chābadā and Sethī sub-castes (M. U. K. Jain 1975: 98-101).

174 This branch splitt off the Uttara Sākhā in 1493 and was closely associated with the Lamecū caste (Joharāpurkara 1958: 132-135, cf. M. U. K. Jain 1975: 101f.).

175 The inscriptions artificially incorporate the names of all famous Digambara ācāryas of the past in one lineage.

176 Joharāpurkara 1958: 44.

177 Shāntā 1985: 137f.

178 Until the nineteenth century, the term bhattâraka was used both by Bīsa Panthī Digambaras and Mūrtipūjaka Śvetāmbara yatis. Today, it is only used by Bīsa Panthī Digambaras.

179 Personal communication of Bhatțārak Lakșmī Sena, Kolhāpura 4 January 2005.

180 Sangave 1980: 317-322.

181 The Śvetāmbaras list the abhrama-varjana pratimā already on the sixth position, before the sacitta-tyāga pratima $\bar{a}$, and call the eleventh stage śramana-bhūta pratim $\bar{a}$ (Williams 1963: 173).

182 Williams 1963: 172 notes that the pratimās were originally conceived as a progressive sequence rather than as alternative options. Jaini 1979: 185 suggests that originally each pratima may have been practiced only of a limited period of time.

183 Williams 1963: 179 found the first mentioning of this distinction in the eleventh century text Śrāvakadharmadohaka by an unknown Digambara author.

184 Hiralāl Jain's view that the word ailaka derives from Skt. acelaka, 'unclothed' or 'partially clothed', was rejected by Williams 1963: 179, n. 5 who pointed out that the ailaka is characterised explicitly as cela-khanda-dhara in the twelfth century Vasunandi-Śrāvakacāra edited by H. Jain.

185 If the sources of Williams 1963/1983: 180 are still of influence, then full access to the 'mysteries' of the scriptures is not granted to lay ascetics. The initiation rituals of the (Vimala Sangha) Digambara munis are detailed in Syādvādmatī 2000: 442-452. Their key ritual elements apart from the acceptance of the respective vows (vratäropana) are: the shaving and pulling out of some of the hair (keśa-luñcana), change of dress/nakedness (nāgnya-pradāna), change of name (nāma-karana), ritual giving of the peacock feather broom (piccha-pradāna), of the scriptures (śāstra-pradāna), and of the water pot (kamandalu-pradāna) (ibid.: 442). The munis receive a large broom (picchi), and all other (lay) ascetics only a small broom (picchikā). For a commented compilation of other textual sources for the Digambara muni dīkșā see Kanakanandī 1994: 214-226. On the basis of incomplete information, Carrithers 1990: 153 suspects that there is little evidence for the existence of a saigha in the Digambara $d \bar{\imath} k s \bar{a}$ rituals: 'there is not even an explicit vow to live in obedience to a guru' and 'no formal recognition of a line of pupillary succession', nor the passing on of a mantra 
(ibid.: 155). He argues that the orientation towards the 'aesthetic standard of self-restraint' is the main element in the transmission of tradition (ibid.: 157). Although his general observation is shared by all modern scholars, mantras of a general nature, oriented toward the veneration of the guru, are prescribed in the dīkșa vidhi texts. For instance: 'namo arahamtānam ... atha gurvāvalīm paṭitvā, amukasya amukanāmā tvam śisya iti kathayitvā samyamādyupakaraṇāni dadyāt' (Syādvādmatī 2000: 447). One of the mantras used for the inauguration of an acārya is: 'om hrīm șrìm arham sah ācāryāya namah. ācāryamantra' (p. 482).

186 Varṇ̄ 1997 I: 468f., II: 188f. Personal communication of Āryikā Muktimatī of the Vimal Sāgar Sañgha, 22.10.2004, and of the bhatțārakas Jina Sena and Lakṣmī Sena, 2-4 January 2005. The rules and regulations cannot be discussed here in detail.

187 Bhattāarakas do not have many śișyas and often ask dedicated followers to send their young sons to take boarding and lodging in their mathas to receive religious training in addition to their secular school education.

188 This happened in the case of Jina Sena of the Nāndan̄i mața.

189 Since the generic name is apparently associated with the bhattäraka lineage there are at least three Lakșmī Senas, of the maṭhas in Kolhāpura, Jinākāññ̄ and Sinhhanagadde (Penagonda in Andrah Pradeś), amongst the contemporary bhattârakas.

190 According to Premī 1912, n.d.: 27, the bhattāakaka dīkșā is - in principle - similar to a muni dīks $\bar{a}$. The bhattäraka can therefore not be categorised as a layman. The ritual, he writes, is prescribed in an ancient book in the Bhandāar of Ị̇ar. There it is stated that a layman can only be installed as a bhattāraka when the search for a worthy muni has failed. The initiation requires the nakedness of the candidate and the ritual plucking of the hair (keśa luñcana). After receiving the sūri mantra, the candidate is attributed with the qualities of an a $\bar{c} \bar{a} r y a$, and continues to practise nakedness when he eats his meals and during certain ceremonies: 'is se sāph mālūm hotā hai ki, bhattāarak vāstav mè் grhastha nahīm hai, muni tathā ācārya haìm' (ibid.: 28). Joharāpurkar, interviewed by Shāntā 1985: 186, n. 99, emphasised that even today's bhattārakas continue to accept five 'mahāvratas' (effectively anuvratas), not only four as often mentioned in the literature, for instance in Flügel 2003a: 8. According to Carrithers 1990: 151, 'the method of succession was derived not from any Jain prescriptions but from the usages of local polity'. This impression is echoed by the views of the bhattāakas Jina Sena and Lakșmī Sena (personal communication 2-4 January 2004).

191 Śruta Sāgara Sūri's sixteenth century commentary of the Satprābhrta, the Șaṭpābhṛtādisamgraha 1.24. See Glasenapp 1925: 72, Joharāpurkar 1958: 89 (original passage reproduced), 91, M. U. K. Jain 1975: 94f., Cort 2002: 41.

192 Cort 2002: 41 quotes Bakhatrām Sāh's Buddhi Vilās of 1770 as the source of the information that 'Bhațārak Prabhācandra of Delhi' [(r. 1253-1327) the predecessor of Padma Nandin (M. U. K. Jain 1975: 95f.)] 'took to wearing a loincloth during the reign of Feroz Sāh Tughluq (1351-1380) at the request of the king'. Cort (ibid.) also cites a discussion of an inscription suggesting the date of 1333. Premī 1912/n.d.: 1f. refers to oral accounts of the events in Delhi. See also Sangave 1980: 269-271, 317-322 and Tuschen 1995: 20f.

193 Dates according to M. U. K. Jain 1975: 95 f.

194 According to Bhatțāraka Lakșmī Sena of Kolhāpura, the name of the first bhattāaka of the Sena Gana was Vidyā Sāgar and the first mathas were established in Dillī, Kolhāpura, Jinākāññ (Tamil Nāḍu) and Penagoṇụa (Andrah Pradeś) - the maṭhas of his associates. Personal communication, Kolhāpura 4 January 2005. V. Śāstrī 1932: 5-7 gives the line of succession of Vidyā Sāgar, whose samādhi is in Akīvāt:Zilā Cikodịi. It comprises some munis, but ends with Bhattāăraka Vidyā Mān (r. 1904 ff.), whose conduct is unfavourably contrasted with Muni Śānti Sāgar's.

195 Lath 1981: lvi. 
196 See Sangave 2001: 136. In 1875-1876, Bühler 1878: 28 visited a bhattāaka in Delhi, who was accompanied by 'ascetics (who are called pandits)'. Bühler described the bhattāarakas he had met during his travels as 'very ignorant'. This statement was still echoed by Sangave 1980: 321f. 100 years later. See Cort (in this volume p. 299 n.9) on the Canderī seat of Bhattāraka Devendrakīrti.

197 Personal communication by the Jain Bhavan in Bangalore 31 December 2005 and by Bhatțāraka Jina Sena, Nāndan̄i 2 February 2005, who seems to be the only bhatțāraka who currently has a disciple, Brahmacārī Vrșabha Sena. According to Tuschen 1997: 23, the seats of Bhațāaraka Viśālakīrti in Lātūr in Mahārāștra (traditionally associated with the Saitavāla caste) and Bhațāraka Yaśakīrti in Pratāpgarh in Rājasthān (traditionally associated with the Narasinhapura caste), which are mentioned by Sangave 2001: 135, are now defunct. This would leave only nine bhattārakas. For the names of more than thirty-six old bhattāraka seats see Joharāpurkara 1958: 6f., M. U. K. Jain 1975: 131, Sangave 2001: 134. In addition to the seats that can be linked to specific traditions, Joharāpurkara 1958: 6f. mentions a number of other, now equally defunct, seats in Eastern India (Ārā), Gujarāt (Navasārī, Bhaḍaurī, Khambhāt, Jāmbūsar, Ghoghā), Mālvā (Devgarh, Dhārā Nagarī, Lalitpur, Mahuā, Ḍ̄ngarpūr, Indaur, Sāgavāọā, Ațer) and Mahārāșțra (branches in Riddhipur, Bālāpur, Rāmațek, Nāndeḍ, Devagiri, Paițhan, Śiraḍ, Vaṇt, Vairāt, Vaphād, Malayakheḍ, Kāryarañjakpur, etc.). There is currently no information on the old seats in the Pañjāb, only on various seats in Dillī. Apart from Merath and Hastināpur, there are no bhatțāraka seats reported from Uttar Pradeś. Sangave 2001: 134 mentions the additional seats of Jehrahat, Keśarīyajī, Mahāvīrjī (Rājasthān), Sonāgiri (Mālvā), Bhanpur, Sojitrā, Kalol (Gujarāt), Nāgpur, Nāndaṇ̄ (Mahārāșțra), Narasinhharājapura (Karṇātạka), Svādī in Sondā (Karṇạtaka) and Melasittamūra, that is Jinakāñoî (Tamil Nāḍu).

198 The seat was established in the eighth century and belongs to the Mūla Sangha Kundakundānvaya Nandi Sañgha Sarasvatī Gaccha Balātkāra Gaṇa (Tuschen 1997: 28). It is associated with the Bogāra caste (Sangave 1980: 318, 2001: 137) and governed by Bhattāraka Devendrakīrti.

199 Associated with the Kṣatriya caste (ibid.), and governed by Bhattāaraka Lalitkīrti.

200 Associated with the Pañcama caste (ibid.), and governed by Bhattāakaka Lakṣmī Sena I (I add Roman numbers to distinguish bhattāarakas with the same title). The seat has two other mațhas under its administration, in Hosūr-Belgāmv and Rāybāg, and is associated with the Sena Gaṇa mațhas in Dillīe, Jinakāñoì and Penagoṇda (Sin̉hanagadd̄̄ in Narasinharājapura). For Lakșmī Sena's works see for instance Sangave 2003.

201 Also called Jinakāñcī. Associated with the Kṣatriya and Vaiśya castes and governed by Bhattāaraka Lakșmī Sena III of the Sena Gana (Sangave 2001: 137).

202 Traditionally associated with the Upādhyāya caste (ibid.). According to P. S. Jaini (personal communication), the last two, including the current Bhattāaraka Cārukīti II, who is a non-Shetty (Śreșthi) Jain, were not of that caste. There is a Trust comprising members of all three local castes (Shetty, non-Shetty, Upādhyāya) who selected the current bhatțāraka (on suggestion of Bhațāraka Cārukīrti of Sravanabeḷagoḷā).

203 The seat is associated with the Caturtha caste (ibid.), 'the only caste among the Jainas which follows agriculture as the main occupation' (Sangave 1980: 96), and is governed by Bhattāaka Jina Sena. The seat has three other mathas under its administration, in Kolhāpura, Tesdāl and Belgāmìv - and in the past also in Dillī.

204 Associated with the Bogāra (and Kșatriya and Vaiśya) caste and governed by Bhațāaraka Lakṣmī Sena II of the Sena Gana (Sangave 2001: 137).

205 The current seat was established in the tenth century and derives its descent from the Mūla Sangha Deśiya Gana Pustaka Gaccha. It is associated with the Vaiśya caste (ibid.) and occupied by Bhațāaraka Cārukīrti I.

206 A summary table of the relationship between specific castes and their principal bhatțäraka seats can be found in Sangave 1980: 318. There were only nine bhațāaraka 


\section{PETER FLÜGEL}

seats left until the head of the Deśiya Gaṇa, Bhattāakaka Cārukīrti of Śravanabelagoḷā, created three more bhattāaraka seats: in Karṇātaka Kambadahalli/Nagamañgala (Bhaț̣āraka Bhānukīrti), and Kanakagiri Mațha in Maleyur (Bhatțāraka Bhuvanakīrti), and in Tamil Nāụu Tiruvannamalai (Bhațāraka Dhavālakīrti). Apart from the Hūmachā Matha, and the Svādī Matha in Sondā which is governed by Bhatțāraka Bhattākalañka, all bhattāraka seats are presently under the authority of Lakșmī Sena of Kolhāpura for the Sena Gaṇa, and of Cārukīrti of Śravanabelagolā for the Deśiya Gaṇa.

207 Many, castes of the Jains were founded by ācāryas and/or bhattārakas. The most important Śvetāmbara castes are the Osvāls and the Śrīmālīs. Of the Digambara Kāsthā Sangha, the Nandītat Gacch leader Rām Sena founded the Narasinhapura caste, his pupil Nemi Sena the Bhațāpurā caste, and the Ratnākar caste was apparently founded by Devendra Kīrti I. Of some Digambara castes the exogamous subgroups (gotra) or/and their dasa and bissa sub-categories are associated with different branches of the main bhattāaraka traditions. The Baghervāla caste was partly founded by the Mūla Sangha ācārya Rām Sena (25 gotras) and partly by the Kāṣthā Sangha ācārya Loha (27 gotras). The Nāgaur branch of the Balātkāra Gaṇa commanded the following of several gotras of the Khaṇ̣elvāla caste etc. (Joharāpurkara 1958: 13).

208 The bhattāarakas of the Humaḍa, Narasinhapura and Khaṇ̣elvāla castes until recently selected their own successor (? Kalol, Narasinhapura), while the bhattāraka of the Saitavāla, Caturtha, Pañcama, Upādhyāya, Bogāra, Vaiśya and Kṣatriya castes were chosen by the representatives ( $p a \tilde{n} c a$ ) of these castes (Sangave 1980: 319f.). The only exception is the influential seat of Śravanabelagoḷā, whose bhattâraka is since 1931 chosen by a committee of lay followers which is selected by the Government of Karnātaka (ibid., Tuschen 1997: 33). Sangave 1980: 319-321 found that only the bhatțarakas of the Humada caste could be removed by their followers in the past. Although they preside over a particular caste, the bhattārakas do not need to be member of the caste and ideally represent all Jains. Lakșmī Sena of Kolhāpura, for instance, was born in Tamil Nāḍ into the Saitavāla caste, but presides over the Pañcama caste.

209 In 1945, the Land Sealing Act of Karṇattaka led to the aquisition of most landholdings of the bhattärakas by the government in exchange for monetary compensation, whose ownership is in many cases still disputed in the courts between the Digambara laity and the bhattārakas.

210 According to Shāntā 1985: 134f., the munis apparently entirely disappeared in the seventeenth century.

211 Shāntā 1985: 134f. A modest revival of the institution of the bhattāakaka was triggered recently because of the desire to spread Jainism across the borders of India and because of a renewed interest in community education. In response to modern demands, the bhațārakas made themselves accessible to members of other castes than their own and created - without much success - a common institutional platform in 1969 and arranged the first bhattāraka sammelan (Sangave 2001: 143), which was followed by several others.

212 Carrithers 1989: 150. In 1926-7, Rāvjī Sakhārām Dośī, in G. P. Jauharī, in V. Sāstrī 1932: 7f., and G. P. Jauharī of the Akhil Bhāratvarșīya Digambara Jain Mahāsabhā (ibid.: 56f.,) emphasised the need to re-introduce the munis to North India to propagate true religion ('jain dharma kī yathārtha tathā utkrșta prabhāvanā'), and unity amongst all Digambara societies in India (ibid.: 84-86).

213 Most Khaṇ̣elvālas live in North India, where no bhattāraka seats exist anymore.

214 Some of the first disciples of Śānti Sāgar, such as Vīr Sāgar and Candra Sāgar, were Khandelvāls. See D. Sāātrī 1985.

215 S. C. Jain 1940: 3f. In the twentieth century, after an earlier failure of transregional sect-caste associations, a number of Digambara Jain caste associations were established with the intention of reforming the Digambara community and creating 
transregional solidarities amongst geographically dispersed North Indian castes with a dominant Digambara Jain membership. The Jain Khaṇdelvāla Mahāsabhā, for instance, which was founded in 1920, is today organised into 15 prāntas, or regions. Other examples are the Baghervāl Jain Mahāsabhā and the Jain Padmāvatī Porvāl Mahāsabhā. Similar organisations which strive to establish independent sect-castes are relatively rare among Śvetāmbara Jains, whose transregional organisations are usually founded exclusively on religious criteria (Kāsalīvāl 1992: 14f.). Cf. R. K. Jain 1999: 67.

216 The anti-printing movement called itself Śāstra-Mudraṇa Virodhī Āndolana: 'Murder threads were made against those involved in printing, and printing shops were blown up' (Sangave 1981/2001: 62).

217 At the time, Jain castes were generally divided in at least two ranked sections: the lower dasa and the higher bissa sub-castes. The following social reforms were advocated by the Parișad: 1 . child widow remarriage (bāla-vidhvā vivāha); 2 . marriage across caste boundaries; 3. allowing members of dasa families to participate in the $p \bar{u} j \bar{a}$ pâtha, etc., within a society where mixed dasa-bisa marriages were practised; 4. abolition of death feasts (marana bhojana); 5. abolition of excessive feasts and giftgiving at pratiștha ceremonies (new pratiștha pạtha: as a rule only old images should be consecrated); 6. raising the status of women through the foundation of womens' institutions (S. C. Jain 1940: 3f.).

218 Kāsalīvāl 1992: 11f. In 1902, the influential Bhāratvarșīya Digambara Jain Tīrtha Kṣetra Kamețī (BDJTKK) was founded by Maṇikcand Hirācand Jauharī (1851-1913) in Bombay as a sub-committee of the Mahāsabhā. It became independent on 24 November 1930 and still has its office in the Hīrābāg Dharmaśālā compound in Mumbāī, owned by the Jauharī family trust. For administrative reasons, it divided India into six zones. Another national association, the Digambara Jain Mahāsamiti, was set up in 1974 by Sāhū Sānti Prasād in New Delhi for the promotion of Digambara unity during the year celebrating Mahāvīra's 2500th death day. In contrast to the Mahāsabhā, which is composed of individuals, it is organised in the form of a 'Jain samsad', or parliament, that is, on the basis of regional representatives (Kāsalīvāl 1992: 12f.). However, after the death of its founder, the organisation failed to deliver and is now defunct. In 1983, the Kundakunda-Kahnā Tīrtha Raksāa Trust was founded in order to promote the worship of Kānjī Svāmī (who declared himself to be a Digambara Terā Panthī) in his putative reincarnation as the tīrthañkara Sūrya Kīrti. This was in 1985 vigorously opposed both by the Mahāsabhā, whose patron saints were Muni Dharma Sāgar and Āryikā Jñān Mātā in Hastīnapur, and by the Mahāsamiti, whose patron saint was Muni Vidyānand in 1985. However, the main representatives of the Mahāsamiti, the Sāhū Jain family (Times of India) and Premcand Jain (Jayna Watch Co.) in Delhi, had once supported Kānjī Svāmī and failed to join the united front against the Kanjī Panth supporters at Songaḍh (R. K. Jain 1999: 114-117). The Meerut Court decided on the 6 December 2000 that Kānjī Panthīs are not Digambara Jains (case no. 9/91, quoted by N. K. Jain, jain friends@yahoogroups.com, 21 June 2001). Both the Mahāsabhā and the Mahāsamiti are dominated by Khandelvāls. A rival organisation to the Tīrtha Kṣetra Kamatị, the Jaina Samrakṣan Māñca, was recently set up in Jaypur, in order to protect old temples from partial demolition and reconstruction under instructions of modern munis.

219 V. Śāstrī 1932: 5 lists a number of 'nigrantha bhattārakas' for the beginning of the nineteenth century. See Carrithers 1990: 148f. and Cort 2002: 71, n. 8 for further references on the so-called nirvān $s v \bar{a} m \bar{\imath} \mathrm{s}$, who did not travel much and seemed to have dressed themselves in public.

220 K. P. Jain 1932: 158, n. 2: 'Mainapurī Digambara Jain Baḍā Mandir kā ek Guṭā'.

221 Ibid., citing Digambara Jain 9, 1: 18-23, ed. Mūlcand Kiśandās Kāpaḍiyā, Surat. 


\section{PETER FLÜGEL}

222 Eternal lights in the form of oil-lamps can be found at a variety of samädhi mandiras for Digambara munis; for instance at the Vimal Sāgar Samādhi Mandira in Madhuban.

223 ibid.: 159, citing Digambara Jain, Special Issue, 1916.

224 Carrithers 1990: 155.

225 K. P. Jain 1932: 159, citing Digambara Jain 14, 5-6: 7; cf. Mahias forthcoming, p. 3.

226 Ibid. His name was Vardhamān Sāgar according to D. Sāstrī 1985: 54.

227 K. P. Jain 1932: 159. His name was Devappā Svāmī according to D. Śāstrī 1985: 55. Carrithers 1990: 155 identifies Devendra Kīrti as a bhațāraka.

228 K. P. Jain 1932: 159. Akkole 1987: 43 writes that the ksullaka dīksāa took place in 1916 and the muni dīkșā in 1976 Phālgun Śuklā 14 (Śaka 1841). All initiations were given by Devendra Kīrti (Ibid.: 51-53, D. Śāstrī 1985: 56).

229 Cf. C. R. Jain 1931, Ghoshal 1932.

230 The original announcement of G. P. Jauharī was published in 1926 in the journal Jaina Bodhaka. It was reprinted by V. Śāstrī 1932: 46-48, whose book gives a detailed account of this momentous pilgrimage.

231 One should assume that the visit to Mount Śikhar would have helped the pending court cases between Digambara, Śvetāmbaras, and the Government concerning the control of the site.

232 K. P. Jain 1932: 161, Kāsalīvāl 1992: 35, Kāsalīvāl 1998, Kāsalīvāl 2001: 36ff., Śruta Samvarddhana Samsthān 2002: 3.

233 Ibid.

234 Ibid.: 3-5, Kāsalīvāl 2001: 26-29. Sūrya Sāgar's main disciples were Vijay Sāgar, Ānand Sāgar, Padma Sāgar and Kṣullaka Cidānand. Vimal Sāgar's main disciples were Nirmal Sāgar, Sumati Sāgar, Kunthu Sāgar and Kṣullaka Dharma Sāgar.

235 For one view of the resulting structure, see Kāsalīvāl 1998: n.p.

236 D. Śāstrī 1985, Rājkul Jain 2003: 213-221. Dates were converted with the computer program of M. Yano and M. Fushimi: http://ccnic15.kyoto-su.ac.jp/yanom/pancanga

237 See Varn̄ī 1998 I: 334, Kāsalīvāl 1992: 30, 34. Personal communication Nīraj Jain, 12 June 2003, D. K. Jain 25 October 2003.

238 P. Śāstrī 1992: 212, cf. Varṇī 1998: 211-216. His childhood name Vidyādhar was derived from the famous 'miracle working' samādhi of Bhattāraka Vidyādhar in Karnātāka (M. Jain 2001: 3). Both his father (Muni Malli Sāgar 1975) and his mother (Āryikā Samay Matī 1975) took dīkșā from Ācārya Dharma Sāgar, and his three brothers (Muni Samay Sāgar 7 March 1980, Muni Yoga Sāgar, Muni Niyam Sāgar 15 April 1980) took $d \bar{\imath} k s ̣ \bar{a}$ from him (ibid.: 29-31). In 2003, his birthhouse has been converted into a temple.

$239 \bar{A} r y i k \bar{a}$ s never receive foods in their hands nor in a standing posture, and apparently do not perform keśa luñcana.

240 The ailakas, kșullakas and kșullikās are also called tyāgīs. See R. K. Jain 1999: 80. Similar debates on the status of women are known from early on (Jaini 1991). According to some early medieval Digambara scriptures, at least some medieval Digambara or Yāpanīya traditions also formed a four-fold sangha, with nuns being recognised as mendicants rather than as laypeople (Schubring 2000: § 30, p. 61).

241 Personal communications by different Digambara śrāvakas.

242 This is emphasised in a proclamation by Ācārya Vimal Sāgar 23 October 1993, reprinted in Brahmacārin̄ī Mainābāī Jain 1996: xv, which requests the laity to mediate the 'foolish' disputes between the two lineages with reference to the common Āgamas: 'samāj kā kartavya hai ki kisī kā vivād na karke donom àcārya paramparāa ko āgam sammat mānakar vātsalya se dharma prabhāvanā karem.' The writings of Ādi Sāgar were published by B. M. Jain 1996.

243 D. Sāstrī 1985: 344, 450-452.

244 His death memorial is in Madhuban at Sammet Śikhara. 
245 The desire to became an $\bar{a} c \bar{a} r y a$ and the abolishment of the once prevalent practice that an a a $\bar{a} r y a$ can be enthroned only after the death of his predecessor have contributed to the creation of many splits and independently roaming ācāryas (personal communication by Nīraj Jain, 12 June 2003).

246 According to Kāsalīvāl 2001: 35 he was a disciple of Mahāvīr Kīrti.

247 Kāsalīvāl 1992: 36-38.

248 D. Śāstrī 1985: 411-413. According to Ācārya Puṣpadanta, he was a disciple of Śānti Sāgar 'Dakșiṇ' (personal communication, Mumbaī 24 October 2003). He was born in Kothalpur in Belgāmv in Karnātaka and died on the 22 May 1987.

249 Vīr Sāgar 'Śolapur' is said to have been close to Kānjī Svāmī’s views, though his interpretation of the texts was slightly different.

250 This line is also claimed by the bhațtâraka of Hūmachā today.

251 Copade 1936.

252 On the dating of Kunda Kunda, see the divergent views of Upadhye 1935: 21 and Dhaky 1991: 193.

253 According to Dhaky (1991), this is because of 'the profound reverence and a very false notion as regards the antiquity of Kundakundācārya' (ibid.: 203, n. 30).

254 Personal correspondance, 25 September 2002.

255 This is also documented by M. U. K. Jain 1975: 126-128, Shāntā 1985: 489, and Carrithers 1989: 232.

256 Personal communication of Nĩraj Jain, 16.6.2003.

257 Including, occasionally, demolishing old temples in order to replace them with new ones.

258 The Agravāla Digambaras, who are dominant in the Pañjāb and in U.P., belong also to mixed Hindu-Jain caste.

259 Critics ask: 'Why only cows?'

260 'vītarāg sādhu kā kō̄ panth nahīm hotā' (P. Śāstrī 1985b: 540).

261 Tuschen 1995: 50.

262 Saletore 1940: 124.

263 For information on the contemporary Digambara ascetics I wish to thank in particular Dr A. Jain, Dr N. L. Jain, Nīraj Jain and Manish Modi.

264 Jaini 1979: 246f., n. 8 reported the number of 175 ascetics in 1979 (65 munis, 60 kșullakas and ailakas and $50 \overline{a r y i k} \bar{a}$ s and kșullikās) and 150-200 in 1991 (Jaini 1991: 24-26). Goonasekere 1986: 27 calculated the figure of 170 munis and altogether 400 mendicants (p. 116). Shāntā 1985: 489 mentioned 62 àryikās and 23 kṣullikās. Zydenbos 1999: 291 heard that there were only 120 munis in 1999 and emphasises their 'decline in numbers'. For 1990, Kāsalīivāl 1992: 35 quotes the figure of 32 ācāryas, 11 upādhyāyas, 130 munis, 154 āryikās, 22 ailakas, 80 kṣullakas and 45 ksullikās. In 1992, Upādhyāya Kanak Nandī cited to me the figure of about 418 Digambara ascetics: 14-15 àcāryas, 2-3 upādhyāyas, 125 munis, 20-25 ailakas, 40-50 kșullakas and about $200 \bar{a} r y i k a \bar{s}$ and kșullikās.

265 In 2002, only Ācārya Vidyā Sāgar provided complete data to B. U. Jain 2002: 324.

266 For 1996, B. U. Jain 1996: 326 gives the following sums, which differ from the detailed information on individual ascetic groups in his own text: 36 àcāryas, 143 cāturmāsa places, 352 munis, 305 äryikās and a total of 657 mendicants. For want of additional information, I was unable to check the extent of the inaccuracy of the figures. I met Muni Ānand Sāgar, who is now an upādhyāya, in 1981. He was then alone and apparently still is. In 1992, I observed that the group of Kunthu Sāgar had in all 34 ascetics, 18 munis, 3 kșullakas, 2 ailakas and $11 \bar{a} r y i k a \bar{s}$, a figure which seems to corroborate B. U. Jain's numbers for 1987. The subsequent decrease in numbers can be explained by Ācārya Kanak Nandī's separation from Kunthu Sāgar in the early 1990s. My third example shows that the true number of ascetics must be much higher. Ācārya Rayan Sāgar who is not included in the table, is listed by B. U. Jain as a single individual 


\section{PETER FLÜGEL}

without mentioning the number of ascetics accompanying him. In 1999, his group had 8 members: 1 àcārya, 1 upādhyāya, 4 munis, 1 ailaka and 1 kṣullaka.

267 Roman alphabet.

268 The word saigha is used for groups of two and more ascetics.

269 On the definition of these categories as 'novices' see Carrithers 1990: 153, Flügel 2001: 76f.

270 There is no equivalent female category because ailakas (elaka) can wear only one loin cloth, which is not considered to be proper for women.

271 The ailācārya corresponds to the upādhyāya amongst the Śvetāmbaras. The Digambara word elācārya is an ancient designation for 'a pontiff of the highest learning and for a qualified teacher of Jain doctrines, a position more or less equivalent of vācaka, vācanācārya, or kșamāśramana or mahattara in the ancient Northern Nirgrantha of which the Svetāmbara Church is the off-shoot. Once a pontiff received the ecclesiastical title of elācārya his original monastic appelation apparently went into the background' (Dhaky 1991: 191).

272 The chosen successor, who is called yuvācārya among the Śvetāmbaras.

273 The titles have been given to only nine monks by the ācāryas Sanmati Sāgar (ācāryakalpa and bālācārya), Kunthu Sāgar (ācāryakalpa 2x, and ailācārya), Ajit Sāgar (ācāryakalpa), and Sumati Sāgar (ailācārya) (A. Jain 2001: 11).

274 For their names, see B. U. Jain's and A. Jain's publications.

275 This is evident in the mixed composition of the ācāryas' groups documented by A. Jain 2001: 1-11. See also Zydenbos 1999: 296f.; who cites questionable estimates that no more than 10-15 Digambara sañghas, headed by an ācârya, exist.

276 The other bigger sanghas are those of Ācārya Dharma Sāgar's successors Abhinandan Sāgar and Vardhaman Sāgar, Deś Bhūṣān's successors Bāhubalī Sāgar and Subal Sāgar, and Vimal Sāgar's successor Virāg Sāgar. Cf. A. Jain 2001: 1-11.

277 The accuracy of the data is confirmed by the identical names in A. Jain's lists. Through the comparison with the names listed by B. U. Jain (2002) the independently roaming groups of munis and āryikās under the command of Vidyā Sāgar can be clearly identified. In 2001 the sangha had 188 members: 63 munis, 10 ailakas, 113 arryikās and 2 kșullakas. The changes between 2001 and 2002 are minimal: in 2002 the group had 3 more divisions of altogether 2 more independently roaming munis, but 2 members less in the ācārya's group, 4 äryikās less, and 2 kṣullakas less (A. Jain 2001). The munis were divided into 17 divisions: the ācārya's group, with 39 members (38 munis including the $\bar{a} c \bar{r} r y a$ and 1 ailaka), and 16 other groups of altogether 25 munis. In addition, 1 unit of 2 ailakas roaming together, and 7 ailakas and 2 ksullakas wandering alone. The 113 arryikās were divided in 17 divisions, which altogether represented $23.6 \%$ of all 72 divisions of Digambara nuns.

278 The word 'group' is not really applicable.

279 R. K. Jain 1999: 80 describes these 'tyāgīs', or renouncers, as regionally oriented 'priests' which can be compared to the bhattärakas, a hypothesis which still needs to be tested.

280 According to B. U. Jain 1999: 372f., Vidyā Sāgar's order is the only mendicant group where the âryikās do not spend cāturmāsa at the same location as the munis.

281 Six groups of altogether forty seven āryikās spent cāturmāsa Kārañjā in Mahārāsṭra (B. U. Jain 2002: 310).

282 According to M. Jain 2001: 494, cf. 539f., Vidyā Sāgar had initiated 195 disciples between 1972 and 2001: 62 munis, 114 āryikās, 10 ailakas, and 9 kṣullakas.

283 Shāntā 1985: 136.

284 Zydenbos 1999: 295. Svarna Matī (1), Viśuddha Matī (1), and Ananta Matī (1) are listed by D. Sāstrī 1985: 555, 567.

285 It happens that individuals, though initiated by other munis, are counted under the name of their new 'dìkșā guru' after changing to a new sanigha. Personal communication by Nìraj Jain, June 2003. 
286 D. Śāstrī 1985: 569.

287 A. Jain 2001: 23.

288 Cf. B. U. Jain 1999: 187, n. 107, cf. 320, $513 f$.

289 R. K. Jain 1999: 90.

290 Kāsalīvāl 1992: 38.

291 This is one of the biggest difference between Digambara ācāryas and bhatțārakas as well as Śvetāmbara ācāryas.

292 See also Zydenbos 1999: 297.

293 This is the oldest method amongst the modern muni sanghas according to Ācārya Puspadanta (personal communication Mumbaī 24 October 2003).

294 B. U. Jain 1996: 326, n. 4 notes an increase of about 100-125 mendicants between 1995 and 1996 and cites details of many new initiations.

295 An estimated figure of $10 \%$ was cited to me, which may be exaggerated.

296 The data are too unreliable to attach much significance to specific changes, such as the diminishing percentage of male mendicants.

297 See Fohr's article in this volume.

298 B U. Jain 2002: 70 gives the summary figure of 12,469 Jain mendicants for the year 2002: Mūrtipūjaka 7,553, Sthānakavāsī 3,331, Terā Panth 691, Digambara 894. In 2005, the figure had risen to 13,307: Mūrtipūjaka 8,061, Sthānakavāsī 3,546, Terāpanthī 692, Digambara 1008 (B. U. Jain 2005: 25).

299 These percentages do not reflect a similar share of the Jain laity, for which no reliable data are available. Many Digambaras are affiliated to reformist lay traditions without separate ascetic orders. The regional, caste and class background of the ascetics also varies. Most of the ascetics of the Sramana Sangha and the independent Sthānakavāsī traditions stem from the Osvāl and Śrīmālī castes in Rājasthān, Madhya Pradeś, Mahārāștra and the Pañjāo, but also from southern India (Shāntā 1985: 333). The Gujarātī Sthānakavāsī traditions and the Tapā Gaccha groups recruit their ascetics almost exclusively in Gujarāt and amongst the Gujarātĩ population in Mumbaī, the Kharatara Gaccha and the Śvetāmbara Terā Panth in Rājasthān, and the Digambara groups mainly in Karnātakaka and Madhya Pradeś, to name only the most important mendicant traditions. The average size of the itinerant groups in 1999 was 4-5 in all four traditions (Mūrtipūjaka 4.6, Sthānakavāsī 4.2, Terā Panth 5.69, Digambara 5.05).

300 The comparison is only meaningful because of the 'improvement in reporting of religion' in the censuses after 1971 (M. K. Jain 1986: 35). The doubling of the absolute number of Jains recorded in the censuses of 1951-1971 (which is not matched by the mendicant population) is generally interpreted as an effect of underreporting during the colonial period. If this is true, then it must be concluded that relative to the total population of India - the number of Jains is continually declining.

301 A variant of this approach is M. Spiro's theory of renunciation as a psychological defense-mechanism, which has been applied to the Jain case by Goonasekere 1986: 179f.

302 This figure more than doubles, if nuns and novices are included. See Bechert 1973: $580 f$.

303 The 2000 edition of the Vatican's Annuario Pontificio, gives for 1998 the figure of 57,813 monks and 814,779 nuns (ratio 1: 14). The monastic population as a whole represented $0.086 \%$ of all Roman Catholics. Overall numbers are declining, especially the population of nuns, which was 990,768 in 1978: http://www.sspxasia. $\mathrm{com} /$ Countires/World/NewsArchive.htm

304 For data confirming this for the Terāpanthīs see Flügel forthcoming.

305 'Socioeconomically troubled families, especially those of the middle classes, often seek relief from their frustrations and insecurities by becoming religious' (Goonasekere 1986: 123).

306 Vallely 2002: 197 tried to solve the problem through re-definition: 'Within the order, desire to belong to the group, or attraction to a charismatic leader, is not treated as a 
"social" motivation, stemming from worldliness. Instead, it too is seen as evidence of a spiritual purity'.

307 Cf. Bloss 1987: 18, Kawanami 1990: 26.

308 'field investigations have revealed that this is more an accusation and a speculation than reality' (Goonasekere 1986: 179f.).

309 E.g. Bordiyā 1975: 265-80. Reasons which are rarely cited in the literature are (a) recruitment drives to satisfy the formal requirement of Mūrtipūjaka monks to have disciples in order to be able to advance in the monastic hierarchy, (b) family pressure informed by material considerations.

310 'In the decades since Independence, with the rise in the age of marriage and the increase in health standards, this [widows becoming $s \bar{a} d h v \bar{\imath} s$, P.F.] has changed. Most Jain women are now married when they are in their early or mid 20 s, and so even if they become widows they most likely have had children. Having to raise the children means that becoming a $s \bar{a} d h v \bar{\imath}$ is less of a realistic option for a widow. Changing social attitudes toward widows also makes it less likely that a Jain widow feels that she has little choice but to become a $s \bar{a} d h v \bar{\imath} .$. Today the vast majority of $s \bar{a} d h v \bar{\imath} s$ have never been married; becoming a $s \bar{a} d h v \bar{l}$ is now seen as an alternative vocation to that of a housewife' (Cort 1989: 111f.).

311 Most but not all $s \bar{a} d h v \bar{\imath} \mathrm{s}$ come from Jain families, while an increasing number of $s \bar{a} d h u$ s are recruited from non-Jain tribal communities who seek material improvements through the association with the Jains. An unresolved difficulty for this interpretation is that, for reasons of tradition, educational opportunities are limited for Mūrtipūjaka $s \bar{a} d h v \bar{s}$.

312 In a personal conversation, the Tapā Gaccha ācārya Jay Sundar Sūri stated that men believe in 'heroism', while women are 'more impressionable, more spiritual' (Mumbaī 23 October 2003). An investigation of the self-reported motives of Terā Panth mendicants showed, however, that 'religious' reasons were more prevalent amongst sādhus rather than $s \bar{a} d h v \bar{i}$ (Flügel, forthcoming). Jay Sundar Sūri's disciples Prem Sundar Vijay and Harsad Vijay explained the increasing number of (male) mendicants with the increasing wealth of the Jain community, which now can afford to lose valuable workforce and to feed a growing community of materially dependent mendicants. Apparently, nowadays families of renouncers are more supportive than in the past (Mumbaī 1 November 2003).

313 By 1982, nine ācāryas alone had initiated some 300 ascetics (munis, ailakas, kṣullakas, āryikās, kșullikās): Śānti Sāgar (20), Vīr Sāgar (23), Śiv Sāgar (28), Dharma Sāgar (61), Vidyā Sāgar (18), Deś Bhūṣaṇ (33), Mahāvīr Kīrti (24), Sanmati Sāgar (26), Vimal Sāgar (65) (D. Śāstrī 1985).

314 At the moment, the increased mobility of the laity compensates only for the migration from rural to urban locations and abroad.

\section{Bibliography}

AISJC = Akhil Bhāratīya Sthānakavāsī Jain Kānfrens (ed.). Akhil Bhāratvarșīya Vardhamaṇ Sthānakavāā̄ Jain Śramaṇ Sarighīya Samācārī. Comp. Saubhāgyamuni 'Kumud'. Dillī: Akhil Bhāratīya Vardhamān Sthānakavāsī Jaina Kānfrens, 1987.

—_. Amrrt-Mahotsav Gaurav Granth. Naī Dillī: Akhil Bhāratvarṣīya Śvetāmbara Sthānakavāsī Jain Kānfrens, 1988.

Akkole, Subhāṣcandra. Śantśreștha Parampūjya 108 Cāritracakravartī Ācāryaśrī Śāntisāgar Caritra. Śolāpūr: Jain Saṃskṛti Saṃrakșak Sañgh, 1987.

Appadurai, Arjun. 'Number in the colonial imagination'. Orientalism and the Postcolonial Predicament. Eds C. A. Breckenridge and P. van der Veer, 314-339. Philadelphia: University of Pennsylvania Press, 1993. 
Baines, Jervoise Athelstane Census of India 1891. General report. London: Eyre \& Spottiswoode, 1893.

Balbir, Nalini. 'Observations sur la secte jaina des Terapanthi'. Bulletin D'Études Indiennes 1 (1983) 39-45.

- ' Recent Developments in a Jaina Tīrtha: Hastinapur (U.P.) - A Preliminary Report'. The History of the Sacred Places in India as Reflected in Traditional Literature. Panels of the VIIth World Sanskrit Conference Vol. II. Ed. H. Bakker. General Editor: Johannes Bronkhorst, 177-191. Leiden: E. J. Brill, 1990.

__. 'La question de l'ordination des enfants en milieu jaina'. Les âges de la vie dans le monde Indien. Ed. Christine Chojnacki, 153-182. Paris: Diffusion de Boccard, 2001.

—. 'The A(ñ)calagaccha Viewed from Inside and from Outside'. Jainism and Early Buddhism. Essays in Honor of Padmanabh S. Jaini. Ed. Olle Qvarnström, 47-77. Fremont: Asian Humanities Press, 2003.

Banks, Marcus. 'Defining Division: An Historical Overview of Jain Social Organization'. Modern Asian Studies 20, 3 (1986) 447-460.

—. Organizing Jainism in India and England. Oxford: Clarendon Press, 1992.

Bechert, Heinz. Buddhismus, Staat und Gesellschaft in den Ländern des Theravāda Buddhismus. Bd. III. Bibliographie, Dokumente, Index. Wiesbaden: Otto Harrassowitz, 1973.

Bharill, Hukam Chand. Kramabaddha Paryaya (Sequence Bound Modifications). Tr. M. Jain. Jaipur: Pandit Todarmal Smarak Trust, 1980/1987.

Bloss, Lowell W. 'The Female Renunciants of Sri Lanka: The Dasasilmattawa'. Journal of the International Association for Buddhist Studies 10, 1 (1987) 7-31.

Böhtlingk, Otto and Rudolph Roth. Sanskrit Wörterbuch. Dritter Theil. St. Petersburg: Kaiserliche Akademie der Wissenschaften, 1861.

Brekke, Torkel. Makers of Modern Indian Religion in the Late Nineteenth Century. Oxford: Oxford University Press, 2002.

Budhmal, Muni. Terāpanth kā Itihās. Pratham Khaṇd: Terāpanth ke Pratham Cār Ācārya. 4th Revised Edition. Calcutta: Jain Śvetāmbar Terāpanth Mahāsabhā Prakāśan, 1964/1995.

Bühler, Georg. 'The Digambara Jainas'. The Indian Antiquary 7 (1878) 28f.

—. 'On the Authenticity of the Jaina Tradition'. Vienna Oriental Journal 1 (1887) 165-180.

_ . 'Further Proofs of the Authenticity of the Jaina Tradition'. Vienna Oriental Journal 4 (1890) 313-331.

Carrithers, Michael. 'Naked Ascetics in Southern Digambar Jainism'. Man (N.S.) 24 (1989) 219-235.

.'Jainism and Buddhism as Enduring Historical Streams'. Journal of the Anthropological Society of Oxford 21, 2 (1990) 141-163.

—. 'On Polytropy: Or the Natural Condition of Spiritual Cosmopolitanism in India: The Digambar Jain Case'. Modern Asian Studies 34, 4 (2000) 831-861.

Clémentin-Ojha, Catherine. 'Ascetics' Rights in Early 19th Century Jaipur (Rajasthan)'. Asceticism and power in South- and Southeast Asia. Eds P. Flügel and G. Houtmann. London: Routledge, forthcoming.

Cohn, Bernard S. (ed.). 'The Census and Objectification in South Asia'. An Anthropologist among the Historians and Other Essays, 224-254. Delhi: Oxford University Press, 1987/1992.

Copaḍe, Tātyā Keśav. Kīrtanopayogī Dharmadivākar Śrī 1008 Ācārya Śāntisāgar Caritra. Bhoj: Rāygauḍā Devagaụsā Pāṭ̂il, 1936. 
Cort, John E. Liberation and Wellbeing: A Study of the Mürtipüjak Jains of North Gujarat. $\mathrm{PhD}$ dissertation, Harvard University, 1989.

Cort, John E. 'The Śvetāmbar Mūrtipūjak Jain Mendicant'. Man (N.S.) 26 (1991) 651-671.

—. 'Fistfights in the Monastery: Calendars, Conflict and Karma among the Jains'. Approaches to Jain Studies: Philosophy, Logic, Rituals and Symbols. Eds N. K. Wagle and O. Qvarnström, 36-59. University of Toronto: Center for South Asian Studies, 1999.

_ Jains in the World: Religious Values and Ideology in India. New York: Oxford University Press, 2001.

—. 'A Tale of Two Cities: On the Origins of Digambara Sectarianism in North India'. Multiple Histories: Culture and Society in the Study of Rajasthan. Eds L. A. Babb, V. Joshi and M. Meister, 39-83. Jaipur: Rawat Publications, 2002.

—. 'A Fifteenth Century Digambara Mystic and his Contemporary Followers: Tāran Tarạ̣ Svāmī and the Tāraṇ Svāmī Panth'. (in this volume).

Darśanavijaya, Muni (comp.). Paț̣āvalī-Samuccaya. Pratham Bhāg. Vīramgām (Gujarāt): Cāritra-Smārak-Granthamālā, 1933.

Degenne, Alain and Michel Forsé. Introducing Social Networks. Tr. by A. Borges. London: Sage, 1994/1999.

Delamaine, Major James. 'On the Sra'waks or Jains'. Transactions of the Royal Asiatic Society of Great Britain and Ireland 1 (1827) 413-438.

Deo, Shantaram Balchandra. History of Jaina Monasticism from Inscriptions and Literature. Poona: Deccan College, 1956.

Desāī, Ratilāl Dīpcand. Sețh Ānandjī Kalyānjū nī Peḍhī no Itihās. Bhag 1-2. Amadāvād: Sețh Ānandjī Kalyānjīi, 1983-1986.

Devendramuni, Ācārya. "Sant Sammelan: Ek Cintan (Śramaṇ Sañgh)." Jain Prakāś (Ānandṛṣi Janma Śatābdī Viśeșāink) 87, 73 (2000) 16-22.

Dhaky, Madhusudan A. 'The Date of Kundakundācārya'. Paṇdit Dalsukhbhā̄ Mālvaniiyā Abhinandana Grantha I. Sampādak: Madhusūdan Dhākī \& Sāgarmal Jain, 187-206 (English Section). Vāranasī: Pārśvanāth Vidyāśrama Śodha Samısthān, 1991.

Dullā, Pāsvīr Vīrjī 'Pārśva Śñ̄’ (Prayojak). Añcalgaccha Digdarśạn. Mulumị̣/Mumbāi: Mulumị Añcalagaccha Jain Samāj, 1968.

Dumont, Louis. Homo Hierarchicus: The Caste System and its Implications. Complete Revised English Edition. Chicago and London: The University of Chicago Press, 1966/ 1980.

Dundas, Paul. 'Somnolent Sūtras: Scriptural Commentary in Śvetāmbara Jainism'. Journal of Indian Philosophy 24 (1996) 73-101.

- The Jains. Second revised edition. London: Routledge, 1992/2002.

—. 'Conversion to Jainism: Historical Perspectives'. Religious Conversion in India: Modes, Motivations, and Meanings. Eds Rowena Robinson and Sathianathan Clarke, 125-148. Oxford: Oxford University Press, 2003.

Flügel, Peter. 'Jain Transactions: Food Restrictions as Interactive Matrices'. DGVSymposium Überbrücker von Unüberbrückbarem, München, 17 October 1991.

- Askese und Devotion: Das rituelle System der Terapanth Svetambara Jains. Doctoral dissertation, Johannes Gutenberg-Universität Mainz, 1994.

_. 'The Ritual Circle of the Terāpanth Śvetāmbara Jains'. Bulletin D'Études Indiennes 13 (1995-1996) 117-176.

- 'Protestantische und Post-Protestantische Jaina-Reformbewegungen: Zur Geschichte und Organisation der Sthānakavāsī I'. Berliner Indologische Studien 13-14 (2000) 37-103. 
'R. K. Jain. 1999. The Universe as Audience: Metaphor and Community among the Jains of North India [review]'. Jinamañjari 23, 1 (2001) 70-77.

- "The Codes of Conduct of the Terāpanth Saman Order." South Asia Research 23, 1 (2003a) 7-53.

-. 'Protestantische und Post-Protestantische Jaina-Reformbewegungen: Zur Geschichte und Organisation der Sthānakavāsī II'. Berliner Indologische Studien 15-17 (2003b) 149-240.

- 'The Invention of Jainism: A Short History of Jaina Studies'. Journal of Jaina Studies (Kyoto) 11 (2005) 1-19 (also: International Journal of Jain Studies 1, 1 (2005) http://www.soas.ac.uk/ijjs).

—. 'The Unknown Lonkā: Tradition and the Cultural Unconscious'. Eds C. Caillat and N. Balbir. Proceedings of the Jaina Panel of the World Sanskrit Conference in Helsinki. Delhi: Motilal Banarsidas (in press).

—. 'A Socio-Demographic Analysis of the Terāpanth Jain Monastic Order in Rājasthān'. Paper delivered at the School of Social Sciences Research Seminar, University of East London, 10 December 2003 (forthcoming).

Folkert, Kendall W. Scripture and Community: Collected Essays on the Jains. Ed. J. E. Cort. Atlanta: Scholars Press, 1993.

Ghoshal, Sarat Chandra. The Digambara Saints of India. Cooch/Behar: Digambar Jain Muni Raksha Committee, 1932.

Glasenapp, Helmuth von. Der Jainismus: Eine indische Erlösungsreligion. Berlin: Alf Häger Verlag, 1925 (English translation: Delhi: Motilal Banarsidas, 1998).

Goonasekere, Ratna Sunilsantha Abhayawardana. Renunciation and Monasticism among the Jainas of India. PhD dissertation. San Diego, CA: University of California, 1986.

Guérinot, A.-A. La Religion Djaina: histoire, doctrine, culte, coutumes, institutions. Paris: Librairie Orientaliste P. Geuthner, 1926.

Hoernle, Rudolph A. F. 'Two Pattavalis of the Sarasvati Gachcha of the Digambara Jains'. Indian Antiquary 20 (1891) 341-361.

—. 'Three Further pattavalis of the Digambaras'. Indian Antiquary 21 (1892) 57-84.

Jacobi, Hermann. 'Kalpasūtra of Bhadrabāhu'. Abhandlungen für die Kunde des Morgenlandes 7, 1 (1879).

—. Jaina Sütras Part I. Sacred Books of the East. Ed. M. Müller. Vol. 22. Oxford: Clarendon Press, 1884.

—. 'Jainismus'. Zeitschrift für Religionswissenschaft 18 (1915) 268-286.

Jain, Anupam (col.). Sampark. Hastināpur: Tīrthañkara R̦̣abhdev Jain Vidvat Mahāsangh, 2000a.

__. Digambara Jaina Sādhu-Sādhvīyom ke Varșāyoga - 2001 kī Sūcī. Indaur: Akhil Bhāratīya Digambara Jaina Mahilā Sanghhațhan, 2000b.

- (col.). Digambara Jaina Sādhu-Sādhvīyom ke Varșāyoga - 2001 kī Sūcī. Indaur: Akhil Bhāratīya Digambara Jaina Mahilā Sanghațan, 2001.

Jain, Bābūlāl 'Ujjavala' (col.). Samagra Jain Cāturmās Sūcī. Bombay: Akhil Bhāratvarșīya Samagra Jaina Cāturmās Sūcī Prakāśan Pariṣad, 1987.

—_ (col.). Samagra Jain Cāturmās Sūcī. Bombay: Akhil Bhāratvarṣīya Samagra Jaina Cāturmāsi Sūcī Prakāśan Parișad, 1990.

_ (col.). Samagra Jain Cāturmās Sūcī. Mumbaī: Jaina Ektā Mahāmanḍal, 1996.

—_ (col.). Samagra Jain Cāturmās Sūcī. Mumbaī: Ujjavala Prakāśan, 1999.

—_ (col.). Samagra Jain Cāturmās Sūcī. Mumbaī: Ujjavala Prakāśan, 2002.

—_ (col.). Samagra Jain Cāturmās Sūcī. Mumbaī: Ujjavala Prakāśan, 2005. 
Jain, Brahmacārin̄ī Mainābāī (comp.). Ācārya Śrī Ādisāgar (An̉kalīkar) kī Jhalak. Dillī Ācārya Śrī Sanmati Sāgar jī Sañgh, 1996.

Jain, Champat Rāy. The Jain Law. Madras, 1926.

- The Nudity of Jain Saints. Delhi: The Jain Mitra Mandal, 1931.

Jaini, Jugmandir Lāl. Jaina Law: 'Bhadrabāhu Saṃhitā'. text with translation and appendix containing full text of an important judgement in a jaini case by the original side of the High Court of Judicature, Indore. The Library of Jaini Literature Vol. IV. Arrah: The Central Jaina Publishing House, 1916.

Jaini, Padmanabh S. 'Bhavyatva and Abhavyatva: A Jaina Doctrine of "Predestination"'. Mahāuīra and his Teachings. Eds A. N. Upadhye, N. Tatia, D. Malvania, M. Mehta, N. Shastri and K. Shastri, 95-111. Bombay: Mahāvīra Nirvāṇa Mahotsava Samiti, 1977. - The Jaina Path of Purification. Berkeley: University of California Press, 1979.

- Gender \& Salvation: Jaina Debates on the Spiritual Liberation of Women. With a Foreword by Robert P. Goldman. Berkeley, CA: University of California Press, 1991.

Jain, Kailash C. Jainism in Rajasthan. Sholapur: Jaina Samskrti Samrakshaka Sangha, 1963.

Jain, Kāmtā Prasād. Digambaratva aur Digambar Muni. Baṛaut: Digambar Jain Yuvā Samiti, 1932/1992.

Jain, K. Rājul. Ācārya Jñānsāgar ke Hind̄̄ Sāhitya kā Samīkṣātmak Adhyayan. Sāngāner: Bhagavān Ṛṣabhdev Granthamālā, 2003.

Jain, M. K. 'A Demographic Analysis on Jains in India'. Jain Journal 21, 2 (1986) 33-51. Jain, Miśrī̄al. Ātmaśilp̄̄ Ācārya Śrī Vidyāsāgar (Jīvan Darśan). Amadāvād: Ahimsāā-Ārmī Mānav Kalyān Jīvdayā Cerițebal Ṭrast 2001.

Jain, Muni Uttam Kamal. Jaina Sects and Schools. Delhi: Concept Publishing, 1975.

Jain, Rākeś (comp.). Bīsvīm Sadī ke Divamigat Jaina Manīṣī. Naī Dillī: Digambara Jaina Sāhitya-Saṃskrti Samrakṣaṇ Samiti, 2002.

Jain, Ravindra K. The Universe as Audience: Metaphor and Community among the Jains of North India. Shimla: Indian Institute of Advanced Study, 1999.

Jain, Sureś Candra. Jain Dharma-Bhūṣan, Dharma-Divāraka Brahmacārī Sítalprasād j̄̄ (kī 61 vīm Jayantī ke Avsar Par Prakāśit). Lakhnaū: Jaina Dharma Pravarddhanī Sabhā, 1940.

Jain Śvetāmbara Conference. Jain Śvetāmbara Directory (Gujarāt). Mumbaī: Jain Śvetāmbara Conference Office, Pāydhunī, 1909.

—. Jain Śvetāmbara Directory. Compiled by Ratancand Bhāstar and Dalsukhbhāī Vādịlāl. Mumbaī: Jain Association of India, 1915.

_. Jain Śvetāmbara Directory. Compiled by Ratancand Bhāstar and Dalsukhbhāī Vāđịilāl. Mumbaī: Jain Association of India, 1916.

Jauharī, Durlabhbhāī. Sādhu-Sammelan kā Itihās. Sampādak: Cimmanasinha Lợhā. Samśodhak: Panḍit Śobhācandra Bhārill. Byāvar: Cimmanasinha Loḍā̄ (Mainejar, Śrī Mahāvīr Priṇting Pres), 1946.

Jhaveri, Thakurdas Bhagavandas (comp.). Shri Bharatvarshiya Digambara Jain Directory. Bombay, 1914.

Jñān Mat̄i, Āryikā. Digambara Muni. 2nd edition. Hastināpur: Digambara Jaina Trilok Śodha Saṃsthān, 1980.

Joharāpurkara, V. P. Bhaț̣āraka Sampradāya. Ślāpura: Jaina Saṃskṛti Samrakṣaka Samgha, 1958.

Joshi, A. P., M. D. Srinivas and J. K. Bajaj. Religious Demography of India. Chennai: Centre for Policy Studies, 2003. 


\section{DEMOGRAPHIC TRENDS IN JAINA MONASTICISM}

Kanakanandī, Upādhyāya. Śramaṇ Sanigha Saṃhitā. Jaypur: Dharmadarśan Vijñān Śodha Saṃsthān, 1994.

Kañcansāgarsūri, Sūryodaysāgar, Abhaysāgar (eds). 1977, 1983. Āgama Jyotirdhara . Vibhāg I-II. Āgamoddhārak Granthamālā Puṣpa 18-19. Kapaḍvañj (Kheḍa): Ramaṇlāl Jecandbhāī.

Kāsalīvāl, Kastūrcand. Jaina Samāj kā Bṛhat Itihās. Vol. 1. Jaypur: Jaina Itihās Prakāśan Sansthān, 1992.

—_ (ed.) Praśamamūrti Ācārya Śāntisāgar Chān̄ī Smṛti Granth. Meraṭh: Ācārya Śāntisāgar Chānī Granthamālā, 1998.

Kațariyā, Milāpbhand. 'Terā Panth aur Bīsa Panth'. Jaina Nibandha Ratnāvalī. Bhāg 1, 383-385. (xerox copy).

Kawanami, Hiroko. 'The Religious Standing of Burmese Nuns (thila shin): The Ten Precepts and Religious Respect Words'. Journal of the International Association of Buddhist Studies 13, 1 (1990) 17-39.

Keshory, Seth Kesree Chand. 'Account of the Terapanthi Sect of Swetambar Jains'. Census of India 1921, Vol. I. India, Part I. Report. Ed. J. T. Marten. Appendix IV, xiii-xiv. Calcutta: Superintendent Government Printing, 1924.

Klatt, Johannes. 'The Samachari-Satakam of Samayasundara and Pattavalis of the Anchala-Gachcha and other Gachchas (Revised with Additions by Ernst Leumann)'. Indian Antiquary 23 (1894) 169-183.

Lath, Mukund. Half a Tale: A Study in the Interrelationship between Autobiography and History. The Adhakathānaka. Translated, introduced and annotated. Jaipur: Rajasthan Prakrit Bharati Sansthan, 1981.

Leumann, Ernst. Die Āvaśyaka-Erzählungen. (Abhandlungen für die Kunde des Morgenlandes herausgegeben von der Deutschen Morgenländischen Gesellschaft. X. Band, No. 2). Leipzig: F. A. Brockhaus, 1934.

—. Übersicht über die Āvaśyaka Literatur. Aus dem Nachlass herausgegeben von Walther Schubring Alt-und Neuindische Studien. Hamburg: De Gruyter, 1934.

Mahias, Marie-Claude. Délivrance et convivialité: Le système culinaire des Jaina. Paris: Éditions de la Maison des Sciences de l'Homme, 1985.

—. 'Āhāra dāna, the Gift of Food to Digambara Ascetics (muni)'. Purushartha (forthcoming).

Maṇilāl, Muni. Śrī Jainadharmano Prācīn Sañkṣipt Itihās ane Prabhu Vīr Paț̣āvalī. Amadāvād: Jīvaṇlāl Chaganlāl Saṅghvī, 1934.

Marriott, McKim (ed.). Village India: Studies in the Little Community. Chicago: University of Chicago Press, 1955.

Mehta, Rama. Inside the Haveli. London: Penguin, 1977/1996.

Mitchell, Clyde. 'The Concept and Use of Social Networks'. Social Networks in Urban Situations: Analyses of Personal Relationships in Central African Towns. Ed. J. C. Mitchell, 1-50. Manchester: Manchester University Press, 1969.

Nair, V. G. Jainism and Terehpanthism. Bangalore: Shri Adinath Jain Svetambar Temple, 1970.

Natarajan, B. Indian Census through a Hundred Years. Part I. Census Centenary Monograph No. 2. Census of India 1971. New Delhi: Office of the Registrar General. Ministry of Home Affairs, 1971.

Nathmal, Muni [now: Ācārya Mahāprajña]. Acharya Bhiksu: The Man and his Philosophy. Translation of Bhikṣu Vicār Darśan by N. Sahal. Cūrū: Ādarś Sāhitya Sanggha Prakāśan, $1959 / 1968$. 
Navratnamal, Muni. Śāsana Samudra. Vol. 1-25. Published by Uttamcand Sethia. Calcutta: Śrī Jain Śvetāmbara Terāpanthī Mahāsabhā Prakāśan \& Lāụnūm, Jain Viśva Bhāratī, 1981ff.

—. Terāpanth Pāvas Pravās. Lāḍnūm: Śrī Jain Śvetāmbar Terāpanthī Sabhā, 1991.

Padmarāja, Paṇịt. A Treatise on Jain Law and Usages. Bombay: Karnatak Press, 1886.

Plowden, W. Chichele Report on the Census of British India taken on the 17th February 1881. Vol. I-III. London: Eyre \& Spottiswoode, 1883.

Prakāśacandra, Muni. $\bar{A}$ Che Aṇagāra Amārā. Mumbaī: Śr̄̄ Naval Śāhitya Prakāsáan Maṇụal, 1989/1998.

Premī, Nāthūrām. "Bhaț̣āraka." Jaina Hitaișī 7 (1912) 59-69, 9: 13-24, 10-11: 1-9; 8, 2 (1913) 57-70 [cited from a reprint of unspecified selections, no date].

—. (ed.). Kavivar Banārsīdās viracit Ardha Kathānaka. Bombay: Hindī Granth Ratnākar, 1957.

Ratna Prabha Vijay, Muni. Śramaṇa Bhagavān Mahāvīra. Vol. 5.2. Ahmedabad: Śrī Jaina Siddhānta Society, 1948.

Reynell, Josephine. Honour, Nurture and Festivity: Aspects of Female Religiosity amongst Jain Women in Jaipur. PhD dissertation, University of Cambridge, 1985.

Śāh, Mālti. Nagarśeṭh Śāntidās Jhaverī. Amadāvād: Gūrjar Grantharatna Kāryālay, 1987.

Saletore, R. N. 'Monastic Life in Śravana Beḷagola.” Jaina Antiquary 5, 4 (1940) 123-132.

Sandesara, Bhogilal, J. 'Kșetrādeśapatțaka issued by Ācārya Vijayadharaṇendrasūri of Tapā Gaccha.' Journal of the Oriental Institute 24 (1974) 228-233.

Sangave, Vilas A. Jaina Community. 2nd revised edition. Bombay: Popular Prakashan, 1959/ 1980.

—. Facets of Jainology: Selected Research Papers on Jain Society, Religion and Culture. Mumbai: Popular Prakashan, 2001.

__ ' 'Karavīravaibhav Śrī Lakșmīsena Bhaț̣̄anak Pīṭh: Paramparā va Kārya'. Pațtācārya Bhatțārak Ratna Svastiśrī Lakṣmīsena Mahāsvāmī Sasțyabdipūrtì Gaurav Añk. Sampādak: Prācārya Śrīdhar Heravāẹe, 1-4. Kolhāpura, 3 August 2003.

Śāstrī, Dharmacandra. Digambara Jain Sādhu Paricay. Sanghastha: Ācārya Dharmasāgara. Dillī: Lālā Śyāmlāl Ṭhekedār, 1985.

Śāstrī, Nāthūlāl. 'Bīs Panth Terah Panth Carcā'. Jain Pracārak (2002) $10 f ., 17$.

Śāstrī, Phūlcand 'Siddhāntācārya' (ed.). Khāniyā Tattva-Carcā. 2 Vols. Jaypur: Ācāryakalpa Paṇụit Ṭoḍarmal Granthamālā, 1967.

—_. 'Songaḍh aur Jainatattvamīmāmsā̄'. Siddhāntācārya Paṇdit Phūlcand Śāstrī Abhinandan-Granth. Ed. Bābūlāl Jain Phāgull, 527-532. Vārāṇasī: Siddhāntācārya Pạ̣̣it Phūlcand Śāstrī Abhinandan Granth Prakāśan Samiti, 1985a.

—_. 'Mūlasanginh Śuddhāmnāyakā Dūsrā Nām hī Terāpanth hai'. Ibid., 535-540, 1985b.

—_. 'Śrī Jin Tāraṇataraṇa aur unkī Kṛtiyām’. Ibid., 385-408, 1985c.

__. Parvār Jain Samāj kā Itihās. Jabalpur: Bhāratvarșīya Digambar Jain Parvār Sabhā, 1992.

Śāstrī, Prakāś Hitaiṣī. 'Jaypur Khāniyā Tattva-Carcā: Ek Samīkṣā’. Siddhāntācārya Paṇdit Phūlcand Śāstrī Abhinandan-Granth. Ed. Bābūlāl Jain Phāgull, 643-661. Vārāṇasī: Siddhāntācārya Paṇdit Phūlcand Śāstrī Abhinandan Granth Prakāśan Samiti, 1985.

Śāstrī, Vamśīdhar. Ācārya Śrī Śāntīsāgar Mahāmuni kā Caritra. Solāpur: Rāvjī Sakhārām Dośī, 1932 (2nd edition, Mumbaī: Gunamālāben Javherī, 1995).

Schubring, Walther. Die Lehre der Jainas. Nach den alten Quellen dargestellt. Berlin: Walter De Gruyter \& Co., 1935. 
- The Doctrine of the Jainas. Described after the Old Sources. Tr. Wolfgang Beurlen. 2nd English edition. Delhi: Motilal Banarsidas, 1962/2000.

—. 'Jinismus'. Die Religionen Indiens III. Hg. v. A. Bareau, Walther Schubring, Christoph von Führer-Haimendorf, 217-242. Stuttgart: Kohlhammer, 1964.

Sen, Amulyachandra. Schools and Sects in Jaina Literature. Calcutta: Visva-Bharati Boos Shop, 1931.

Shāntā, N. La Voie Jaina: Histoire, Spiritualité, Vie des ascètes pèlerines de l'Inde. Paris: OEIL, 1985.

Sharma, Jagdish P. 'Jainas as a Minority in Indian Society and History'. Jain Journal 10, 4 (1976) 137-148.

- 'The Jinasattvas: Class and Gender in the Social Origins of Jaina Heroes'. Approaches to Jain Studies: Philosophy, Logic, Rituals and Symbols. Eds N. K. Wagle and O. Qvarnström, 72-85. University of Toronto: Center for South Asian Studies, 1999.

Śīlcandra Vijay, Muni. Śāsan Samrāt. Ahmedabad: Tapāgacchīya Śethśrī Jinadās Dharmadās Dhārmik Trust, Kadambagiri Vāṭ̄, 1973.

Singh, Munshi Hardyal. Report on the Census of 1891. Vol. II. The Castes of Marwar. Illustrated. Jodhpur: Published by the Order of the Marwar Darbar, 1894.

Śivprasād. Tapāgacch kā Itihās. Bhāg 1, Khaṇ̣ 1. Vārāṇasī: Pārśvanāth Vidyāpīth, 2000. —. Añcalgacch kā Itihās. Vārāṇasī: Pārśvanāth Vidyāpīṭh, 2001.

SJCS = Samagra Jain Cāturmās Sūcī Prakāśan Pariṣad Bambaī. 'Pariṣad ke Baṛte Kadam'. Samagra Jain Cāturmāsi Sūcī. Ed. B. U. Jain, 67f. Bombay: Akhil Bhāratīya Samagra Jaina Cāturmās Sūcī Prakāśan Parișad, 1987.

Śrut Samvarddhan Saṃsthān (Ed.). Śrut Samvvarddhan Saṃsthān dvārā Pravartit Pāñc Śrut Samvarddhan Vārșik Puraskārom evam Sarāk Puraskār Varș - 2002: Paricay Pustikā. Preraṇāstrot Upādhyāy Muni Jñānsāgar. Meraṭh: Śrut Samvarddhan Saṃsthān, 2002.

Syādvādmatī, Āryikā (comp.). Vimal Bhakti Saṃraha. Vārāṇāsī: Bhāratvarșīya Anekānt Vidvat Parișad, 2000.

Tāraṇataraṇasvāmī. Śrāvakācāra. Anuvādak: Brahmacārī Sītalprasād. Sūrat: Śrī Tāraṇataraṇa Samāj ke Jain Caityālay - Sāgar K̄̄ Or Se, Mathurāprasād Bajāj, Barā Bājār, 1933.

Ṭhāṇa = Thāṇa (Sthānāinga Sūtra). Vācanā Pramukha: Ācārya Tulsī. Sampādaka Vivecaka: Muni Nathamala. Lāẹnūm: Jaina Viśva Bhāratī, 1976.

Tomgia, V. G. 'Changing Patterns of the Status of Women in the Jain Community. Traditional and Modern Trends in their Status'. Indian Journal of Social Research 32 (1991) 283-288.

Ṭongyā, Rameś, Amit Ṭongyā and Atul Pātedī (comp.). Ācārya Śrī 108 Vidyāsāgarj̄̄ Mahārāj Sasaìgh. Gommațagiri - Indaur Cāturmās 1999. Sañgh Paricay evam Āhārdān Vidhi. Indaur: Sugan Grāphiks \& Ṭoṅkyā Ṭelīkamyūnikeśans, 1999.

Tuschen, Stefanie. Das Bhațtāraka-Amt bei den Digambara-Jainas in Karṇātaka. Magisterarbeit, Philipps-Universität Marburg, 1997.

Upadhye, Adinath Neminath. 'Introduction'. Śrī Kundakundācārya's Pravacanasāra (Pavayanasāra). A Pro-Canonical Text of the Jainas (2nd edition), i-cxxvi. Bombay: Sheth Manilal Revashankar Jhaveri (Rāyacandra-Jaina-S̄āstra-Mālā 9), (1930) 1935

_. 'Yāpanīya Sangha: A Jaina Sect'. Journal of the University of Bombay 1, 4 (1933) 224-231.

—. 'A Pattāavalī of the Senagana'. Jaina Antiquary 13, 2 (1948) 1-9.

—. 'On the meaning of Yāpanīya'. S. Srikantha Sastri Felicitation Volume, 197-198. Mysore, 1973. 
Upadhye, Adinath Neminath. 'More Light on the Yāpanīya Sangha'. Annals of the Bhandarkar Oriental Research Institute 55, 1-4 (1974) 9-22.

Vallée-Poussin, Charles Louis Joseph, de la. 'Religious Orders (Indian)'. Encyclopaedia of Religion and Ethics Vol. 10. Ed. Hastings, 715-718. Edinburgh: T. \& T. Clark, 1918.

Vallely, Anne. Guardians of the Transcendent: An Ethnography of a Jain Ascetic Community. Toronto: University of Toronto Press, 2002.

Varṇī, Kṣullaka Jinendra. Jainendra Siddhānta Kośa. Bhāg I-V. Chațā Saṃskaraṇ. Naī Dillī: Bhāratīya Jñānpịth, 1970/1998.

Vidvatratna, Sumerucandra Divākara. Cāritra Cakravartī. Śraman Siromaṇa Suvargīya Ācārya Śāntīsāgar Mahārāja kā Punya-Cāritra. Vārāṇasī: Mahāvīra Press, 1972.

Vijayanunni, M. Religion. Census of India 1991. Series 1. India. Paper 1 of 1995. New Delhi.

Weber, Max. Gesammelte Aufsätze zur Religionssoziologie. Bd. II. Tübingen: J.C.B. Mohr (Paul Siebeck), 1920/1978.

- Wirtschaft und Gesellschaft: Grundriß der Verstehenden Soziologie. Studienausgabe. Ed. Winckelmann. Tübingen: J.C.B. Mohr (Paul Siebeck), 1920/1978. Williams, Robert H. B. Jaina Yoga. Delhi: Motilal Banarsidas, 1963/1983.

Zydenbos, Robert J. 'The Ritual Giving of Food to a Digambara Renunciant'. Approaches to Jain Studies: Philosophy, Logic, Rituals and Symbols. Eds N. K. Wagle and O. Qvarnström, 291-303. University of Toronto: Center for South Asian Studies, 1999. 